After the Fall: Revisioning the Cold War: A Report on the XVIIth IAMHIST Conference, 25-31 July 1997, Salisbury MD

By John C. Tibbetts

“The past can be seized only as an image," wrote Walter Benjamin. But if that image is ignored by the present, it "threatens to disappear irretrievably." [1] One such image, evocative of the past and provocative for our present, appears in a documentary film by the United States Information Agency, The Wall (1963). Midway through its account of everyday life in a divided Berlin, a man is seen standing on an elevation above the Wall, sending out hand signals to children on the other side in the Eastern Sector. With voice communication forbidden by the Soviets, he has only the choreography of his hands and fingers with which to print messages onto the air. Now, almost forty years later, the scene resonates with an almost unbearable poignancy. From the depths of the Cold War, the man seems to be gesturing to us. But his message is unclear and its context obscure. [2] The intervening gulf of years has become a barrier just as impassable as the Wall once was.

Or has it? The Wall was just one of dozens of screenings and presentations at the recent "Knaves, Fools, and Heroes: Film and Television Representations of the Cold War"- convened as a joint endeavor of IAMHist and the Literature/Film Association, 25-31 July 1997, at Salisbury State University, in Salisbury, Marylandthat suggested that the Cold War is as relevant to our present as it is to our past. In the last eight years, the Wall has fallen, a string of authoritarian regimes in Central Europe has collapsed, the two Germanys have been reunited into a sovereign state, the Soviet 
COLD WAR/ Tibbetts/ 2

empire has imploded, and Communism, as an ideology of government, has virtually disappeared. Consequently, documents have been declassified, and archives and film vaults have been unlocked. Researchers are busily rebutting and confirming, by turns, the accepted findings of previous decades. Filmmakers are trading in KGB agents for maverick terrorists and drug lords. Faces— like the man gesturing from the Wall—are emerging from the nameless crowd. The vast, murky fresco of democrats and despots, of confrontation and containment, of bravado and betrayal is coming into sharper focus. And the role of the media - the relationship between journalism and entertainment, indoctrination and education, fact and fiction-is being reexamined.

This epilogue to the Cold War, then, may be best compared not to the cadence that completes an unresolved chord, but to the ongoing series of overtones that generate outward from that chord.

I must pause a moment to note that in the pages that follow, my sketch, or ebauche, of the Conference, inevitably leaves out many details. Although I tried to attend as many of the events and presentations as possible, I was obviously unable to audit them all. I extend my apologies to those personages who have unfortunately been omitted from this account.

\section{UPDATING THE HISTORIOGRAPHY}

The IAMHist Conference comes hard on the heels - and in some ways is the legatee —of a tremendous spurt in recent Cold War-related research. A few examples from the last three years suffice. John Lewis Gaddis' We Now Know: Rethinking $\underline{\text { Cold War History and Vladislav Zubok and Constantine Pleshakov's Inside the }}$ 


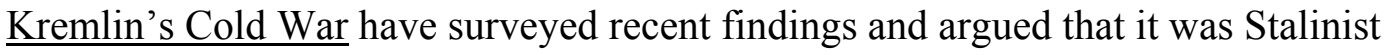
policies, not American agendas, that was primarily responsible for Cold War escalations. While Ann Tusa's The Last Division: A History of Berlin, 1945-1989 was critical of the "ineffectual and timorous behavior of the Western Powers" that prolonged the Cold War stalemate, Charles S. Maier's Dissolution: The Crisis of Communism and the End of East Germany contended that the patience of the Western Powers paid off in the long run. Apart from either argument, Mark Galeotti's Gorbachev and His Revolution and David Satter's Age of Delerium claimed that the Soviet collapse was more a result of, respectively, Gorbachev's catalysing policies within a stagnating and moribund Soviet regime, and the inflexibility of Communism's agenda of brute social engineering and its materialistic interpretation of mankind. Revelations of espionage on both sides have been chronicled in Anne McElvoy's Man Without a Face (spymaster General Markus Wolf of the GDR), John Barron's Operation Solo (CPUSA member Morris Childs, in reality an American agent), Pete Earley's Confessions of a Spy (Aldrich Ames, a KGB agent in the CIA), and two exposes of FBI and CIA assassination plots and political overthrows (Paul Brodeur's $\underline{\text { Secrets }}$ and Richard M. Bissell's Reflections of a Cold Warrior: From Yalta to the Bay of Pigs). Anti-communist investigations by both HUAC and Joseph McCarthy have been examined in Albert Fried's McCarthyism, Mike Nielsen and Gene Mailes' Hollywood's Other Blacklist, Sam Tanenhaus' Whittaker Chambers: A Biography, and screenwriter Walter Bernstein's memoir, Inside Out.

The history of the Cold War, hitherto seen from within, has now shifted to a history of that history, examined posthumously, as it were, from a presumably more 
objective perspective. But, like that other Cold War, there has been little consensus in the new historiography. It's as if the ideologies that once divided capitalism and communism have been reformatted as divisions between conservatives and liberals of the Right and Left. Historians, commentators, and media specialists on either side of the philosophical and cultural divide have found a new bone to chew. A new "cold war" continues as the two camps claim their positions and plant their flags. It's as if, declared Wilhelm van Kampen in the post-mortem IAMHist meeting (chaired by David Culbert and David Ellwood) following the conclusion of the Conference, the Cold War has lost its historical specificity and has now become a metaphor for an unresolved conflict that recycles its way into the future.

The conservative view surfaced in the plenary panel, "The Cold War and Communism: Updating the Historiography," chaired by Peter Rollins of Oklahoma State University. Rollins has long been critical of the liberal media. As a consultant for the Accuracy in Media response to the PBS series, Vietnam: A Televised History, he attacked what he alleged was its anti-military bias. At the Conference, he and three speakers questioned what used to be considered a revisionist view of the Cold Wari.e., that it was primarily American saber rattling, not Soviet aggression, that fomented Cold War hysteria; that the Communist Party played only a negligible role in America during this period; that there was little effective Soviet spy infiltration of the U.S.; that HUAC investigations and the subsequent Hollywood Blacklist were unwarranted victimizations of innocent, or, at the very least, naive, people; that the Rosenbergs (one of them, at least) and Alger Hiss were innocent; etc. 
COLD WAR/ Tibbetts/ 5

I might add that this anti-anti-Communism (what Lionel Trilling called "that meeching phrase") has indeed persisted, surviving the death of Communism itself. As recently as the publication of George Kennan's At a Century's Ending: Reflections, $\underline{1982-1995}$ (1996), for example, we find that the man who defined the American policy of "containment" in 1947 is now defending his subsequent conviction that militarizing Europe's territory around a superpower confrontation kept the Soviets from withdrawing from their positions; moreover, it corrupted Europe's self-reliance and spawned a military-industrial complex in America itself. [3]

"For several years now, we have labored under the revisionist view that the Soviet Union was forced to produce its massive war machine because of its fear of encirclement," argued Rollins in his opening remarks. "According to this interpretation, the Soviet Cold War military buildup and posturing was really induced by the massive military buildup of the United States and its allies." Rollins drily noted this thesis had become pervasive by the mid-1980s — exemplified by Barbara Margolis' award-winning documentary of the Cold War years, Are We Winning, Mommy? (1987), which had been screened the evening before (and which during a postscreening discussion, had came under attack for allegedly parroting this leftist interpretation of events).

Can it be, Rollins suggested, that once our blinders are off, there is indeed a new story to be told? We must be willing to move beyond the accepted paradigms and reassess the Cold War. "Otherwise," he concluded, "we hazard the danger of doing mere re-runs of existing work. Let's approach the subject with fresh information and a new historiography. The work of the scholars here have made me aware of the 
COLD WAR/ Tibbetts/ 6

limitations of my own early Cold War studies. Hopefully, all of us can gain new perspectives on the Cold War."

Rollins was followed by John E. Haynes, of the Manuscript Division of the Library of Congress, the editor of the Newsletter of the Historians of American $\underline{\text { Communism and, with Harvey Klehr of Emory University, the editor of The American }}$ Communist Movement: Storming Heaven Itself (1992). Haynes explained that The Historians of American Communism organization has been in existence for 16 years and is comprised of members from a variety of backgrounds, former members of HUAC, and of both Communist and anti-Communist persuasions. Its main focus is the American Communist Party (CPUSA), whether its policies and meaning resided in its links to Soviet Russia, or if it grew out of essentially American roots, with only superficial connections to the Soviets. As an example of the latter view, Haynes cited David Caute's The Great Fear: The Anti-Communist Purge Under Truman and Eisenhower (1990), which flatly declared that "there is no documentation in the public record of a direct connection between the American Communist Party and espionage during the entire postwar period." As a consequence, concluded Caute's book, America's paranoia about the "Red Menace" was largely a figment of its own paranoid imaginations. It is this latter view that has prevailed for the last twenty years.

Haynes spoke about two important archival finds that may force a review of this position. Since the Soviet Union came apart a little over five years ago, he and other historians and archivists have awaited the opening of long-sealed archives in Moscow and other capitals of the former Eastern bloc, hoping to shed new light on old questions. In 1992, Haynes and Klehr brought back from Moscow startling documents 
from the records of the Communist International (better known as Comintern) dealing with the activities of Communism in America. In addition, the existence of the records of the American Communist Party (CPUSA) were located. They had been secretly shipped to Moscow and hidden for many decades. That these records even existed had been only the subject of rumor and speculation. This archive of 150 million documents was found in the Russian Center for the Preservation and Study of Documents of Recent History, the principal repository of Soviet Communist Party documents that spanned the years from the Bolshevik Revolution to the death of Stalin in 1953. As a result of several trips to Moscow, beginning in 1993, Haynes examined 4300 file folders - thousands of pages — relating to the years 1919-1944. He has published The Secret World of American Communism, co-edited by Harvey Klehr and Friedrich Firsob (1995), Volume One of a projected series by Yale University Press. Volume Two, The Soviet World of American Communism, is forthcoming in January 1998. Many of the findings in Volume One contradict accepted revisionist views. It deals primarily with underground espionage in the 1930s and the enormous amounts of money Moscow spent to promote that espionage. It was found that a young Armand Hammer had helped to launder Soviet money; that the CPUSA had active ties to Soviet intelligence operations; and that the CPUSA had established secret caucuses in agencies like the Civil Liberties Subcommittee of the Senate Labor and Education Committee and the Office of War Information. [Regarding the OWI connection, it should be remembered that this came at a time when the Soviets and the Americans were allies.] 
COLD WAR/ Tibbetts/ 8

The second volume deals with the Soviet's relationship with the American Communist Party. Unfortunately, some of the most significant material is not yet available to the West. The Foreign Intelligence Service of Russia, while releasing some material, has not opened to general research the archives of its Soviet-era predecessors, like the KGB. Nonetheless, concludes Hayes, "It will no longer be possible for any historians interested in the overall history of American Communism to write without using the American Party records, which are in Moscow, and Moscow's own records about the American movement."

The second new source is the cache of so-called Venona Papers, named after a secret U.S. government project to decipher World War II cables between Soviet diplomatic offices in the U.S. and Moscow. For a long time certain Soviet ciphers, the so-called "One-Time Pads," were considered undecipherable. These were codes devised for one-time use only. But during the course of the war, the Soviets grew lazy and began using some of these codes over again. As a result, about 5,000 pages of cables from America to Russia have been decoded. They reveal information about extensive Soviet intelligence operations among some 400 highly-placed Soviet agents in America. Revelations include evidence that many of the Americans who spied for the Soviets were members of the American Communist Party; that the Rosenbergs (one of them, at least) and Alger Hiss were guilty; that at least one White House aide, Laughlin Currie, cooperated with Soviet intelligence; and that the highest ranking civil servant in the U.S. Treasury, Harry Dexter White, spied for the Soviet Union. In 1995 The National Security Agency declassified these documents, put them on the Internet, 
COLD WAR/ Tibbetts/ 9

and made them available to selected libraries. A book is in preparation for the Yale University Press.

What, Haynes asked, may we conclude from all these new findings? Arthur Schlesinger's statement in 1949 seems quite prescient, i.e., that although the American Communist Party was obviously negligible in itself as a political force, it had much greater influence as a powerful "underground apparatus and through the collaboration of fellow travellers." [4] Seemingly, furthered Haynes, the view that there was no meaningful link between American communism and Soviet communism, or between the American Communist party and Soviet espionage, is, in the light of the new evidence, unsustainable. For example, it is Haynes' contention that the National

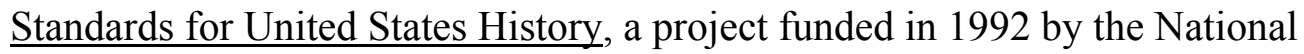
Endowment for the Humanities, the Office of Educational Research, and Improvement of the United States Department of Education, repeatedly condemns McCarthyism as an unmitigated evil [which, at least in its public impact, was true] and treats the Hiss and Rosenberg episodes with shifty ambivalence (neither denying nor asserting their guilt). Of the active participation of the American Communist Party in Soviet espionage, there is silence. In Haynes' opinion, “these silences about key facts of the postwar era demonstrate an unwillingness to face the truth. ... One cannot deny that American communism was bound heart and soul to Joseph Stalin. Nor can one deny that the American Communist Party as an institution as well as hundreds of American Communists as individuals cooperated with Soviet intelligence services in espionage against the United States." [5] 
As a further comment to this, I would add that by now it is well known that Federal agents, in turn, heavily infiltrated the CPUSA. According to a recent article by Ronald Radosh, "American anti-Communists used to joke that, were it not for the FBI, the party would quickly go out of business." The interested reader is referred to John Barron's Operation Solo (1997). [6]

The second speaker, Richard C. Raack, Professor Emeritus, School of Arts, Letters, and Social Sciences, California State University, supported the contention that our Cold War fears of the Soviets were justified. New findings, he claimed, place the blame for military escalation squarely on Stalin. Indeed, Stalin and Chairmain Mao were the sole authors of the Korean War. The revisionist literature that softened the blame is now revealed as a lie. "You can throw out the Cold War texts and films," Raack declared with a broad sweep of his arm, "Soviet claims of peaceful motives are lies." The agendas of Lenin and Stalin were quite clearly expansionist. Their own words condemn them. As early as 1919 Lenin was formulating the Soviet plan to dominate other countries. After 1923 Stalin was saying the same things. In conclusion, Raack produced a document [whose authenticity has been disputed] purporting to be a 1939 statement by Stalin himself. It outlines a strategy of Soviet aggression to conquer the West: "Comrades, it is in the interests of the USSR - the motherland of the working class - that war should break out between the Reich and the capitalist Anglo-French bloc. We must insure the war lasts as long as possible with the purpose of weakening both sides. ... We shall have a broad field of activity for the development of the world revolution.” 
The third speaker, Daniel Leab, Professor of History at Seton Hall University and General Secretary of the Historians of American Communism, was in general agreement with his colleagues. Turning to the subject of the Hollywood Blacklist, he noted that although today we tend to regard the Hollywood Ten with sympathy, we find upon reviewing the subject that they opportunistically exploited what we would now call a "victim" sensibility. [I would add that this is seen in AMC's documentary, Christopher Koch's Blacklist: Hollywood on Trial (1995), in which the blacklistees are portrayed more as victimized idealists still pronouncing Popular Front slogans, than as — in the case of John Howard Lawson, certainly — activist Party members.] Leab even claimed that many blacklisted writers and directors had more success working their trade in the 1950s than is generally acknowledged. In the open forum following his talk, Leab cited the example of Walter Bernstein. Bernstein, of course, was the blacklisted New York writer who was boycotted by Hollywood studios for eight years and by the television networks for another three. He never denied he was a Communist. He joined the party in 1946 and remained a member for the next ten years, resigning only after the Red Army's crushing of the counter-revolution in Hungary. Years later he turned his story into a screenplay for Martin Ritt's The Front (1976), and most recently into a memoir, Inside Out (1996). Leab questioned Bernstein's “self-serving” portrait of himself in Inside Out as a hapless victim of the Blacklist. While acknowledging Bernstein's subsequent difficulties, Leab asserted that Bernstein was indeed able to keep working. He and Abraham Polonsky wrote most of the You Are There segments, for example — a fact in stark contrast to what he might have faced in a Soviet regime in reverse circumstances. (Bernstein's script for The 
COLD WAR/ Tibbetts/ 12

Front was discussed several days later in a presentation by Victoria Stiles of SUNY at Cortland.)

\section{HOLLYWOOD AND THE RED MENACE}

As the political climate continually shifted and changed in the years spanning the 1917 Revolution to the height of World War II, so too did Hollywood's portrayal of the Soviet ideology and people. Michael S. Shull, of the Washington Center, tracked these changing images in a series of films from the late 'teens through the late 1930s. Dangerous Hours (1920), on the heels of the Revolution, vented the first wave of American distrust and paranoia in its depiction of "Reds" as rampaging beasts; $\underline{\text { Clear }}$ All Wires (1932), in the more accommodating context of the early 1930s, saw them as eccentrics and crackpots; and Comrade X (1940), on the heels of the Nazi-Soviet Pact, returned to the image of the vicious, brutal Red.

In his “Uncle Joe Joins the Family,” David Wilt, Librarian, University of Maryland, College Park, discussed yet another shift in attitude in Hollywood's portrayal of the Soviet Union. In a story by now familiar to most of us - see particularly Clayton R. Koppes and Gregory D. Black's Hollywood Goes to War (1987) - Hollywood began at the outbreak of World War II to depict the Russian people in a sympathetic light in an attempt to win audience support toward our new allies. The strategy included avoiding references to pre-War Soviet activities (especially the Nazi-Soviet Pact) and ignoring ideological discussions. Accordingly, the words "Red," "Soviet," and "communism" were replaced by the generic term, "Russian." In his survey of ninety Hollywood wartime films, Wilt claims that Stalin's 
name was mentioned only eighteen times. In general, Stalin's image was whitewashed in Foreign Agent, Days of Glory, The North Star, Song of Russia, The Boy

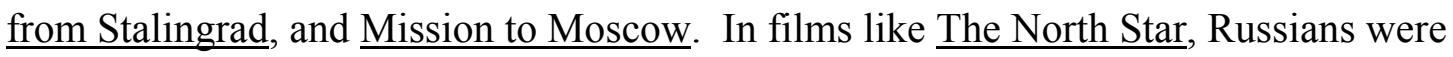
portrayed as happy villagers living in cozy towns; individualists all, who attended church ceremonies and worked closely with the Allies. They were generally recast in the American image, a fact confirmed in the casting of Americans in Russian roles.

Parenthetically, I think it would be instructive to compare these portraits of Russian life with contemporaneous Soviet musicals and comedies produced by Grigori Alexandrov and Ivan Pyriev. These are examined in Dana Ranga and Andrew Horn's fascinating documentary, East Side Story. [7]

In the early 1950s, as Ron Briley, of Sandia Preparatory School in Albuquerque, demonstrated, John Wayne's Big Jim McLain (1952) set the standard for anti-communist pictures. This was particularly ironic - and Garry Will's recent study, John Wayne: The Politics of Celebrity (1997) bears this out_-in that Wayne, who successfully evaded military duty during the war, did not become a devout anticommunist until around 1948, when the victory of pro-blacklist forces made it expedient for him to do so (he subsequently became President of the Committee for the Preservation of American Ideals and later joined the John Birch Society). Briley argued that McLain's angry denunciation of communists who hid behind the First Amendment resurfaced in Wayne's The Green Berets (1968), when Vietnam war protestors were singled out for villification.

Regarding cinematic reflections of the Korean War, Susan Carruthers of the University of Wales, Aberystwyth - aided by several substantial citations from the 
research of historian Thomas Doherty_discussed the ultimate Cold War fear, the "brain washing" of American prisoners of war (a term coined in 1950 by journalist/CIA operative Edward Hunter). It arose from the supposition that if science could unlock the secrets of nuclear fission, it could also unlock the mysteries of the human mind. As early as the winter of 1950-51, American television viewers were learning about the plight of Americans captured by the Chinese troops. Universal Newsreel coverage depicted some newly released prisoners who were in obviously pitiful condition. Over these images a commentator proclaimed: "These are American soldiers who dedicated themselves to the United Nation's fight for freedom!"

John Frankenheimer's The Manchurian Candidate (1962), adapted from Donald Condon's novel, contends that many of these American prisoners of war had been subjected to mind-altering techniques. There had long been a controversy about the extent to which the surviving 3000 American prisoners of war cooperated with the Chinese Communists. Some returning POWs, suspected of being either willing collaborators or victims of mind-altering techniques, were even sent to a "debrainwashing" facility in Valley Forge in California before their release back into society. Frankenheimer was familiar with the literature surrounding this sad episode in recent history, and he cited Eugene Kinkead's In Every War But One (1959) as a particularly important influence on the film. "The 'fifties fear of bodily or mental invasion by external forces is, after all, one closely associated with the science fiction genre," said Carruthers, "[and] in many respects The Manchurian Candidate seems to owe more to these films than to Hollywood's other 'straight' treatment of the brainwashing of Korean POWs — The Rack (1956) — which was neither a popular nor 
critical success, and has been little remembered subsequently." Finally, argues Carruthers, the film makes it clear that the real villain was located from within, not without. Any influence exerted upon the POWs, such as it was, was more attributable to their own degeneracy, malleability, and lack of self will than to any external manipulation. Further, any attempts to blame the Chinese Communists for brain washing — a dubious assertion, at best—should be re-directed elsewhere, specifically, to the "mind control" techniques pursued right here at home- by the CIA.

Cold War paranoia was also discussed in two groups of relatively non-political films. The first, examined by Glenn Scott Allen of Towson University and Garrett Rutherford Chaffin of New York University, was a cycle of horror and science fiction movies. In a subject all too familiar to most auditors, Allen made the surprising disclosure that only two films of the time, The Whip Hand (1952) and 1984 (1956), actually contained specific references to communism. Chaffin linked the explosion of cinematic special effects technology, especially in War of the Worlds (1953), to technological advances in nuclear warfare. The second group included the nihilistic, noirish cycle of films by Phil Carlson. "He was the filmmaker par excellence of 1950s paranoia," asserted David Sanjek of Broadcast Music Inc. "There were no stylish affections or preachy political sentiments, just a blunt and sobering confrontation with the bleak urban landscape."

While paying obeisance to Hollywood films like I Was a Communist for the FBI, Garth Jowett of the University of Houston delved deeper into the exotica of American pop culture. His amusing slide-show banter accompanied images of movie posters, comic books (remember Blackhawk?), and bubble-gun cards (as in the series, 
“The Children's Crusade Against Communism"). "We have to go beyond seeking out the obvious political allegories in '50s films," Jowett told this writer in a later interview. "It's like shooting ducks in a barrel when you start picking on obvious things like Invasion of the Body Snatchers. Not only has it been done to death, but it can be read in many different ways. There are other films that depict American society in more subtle ways. Blackboard Jungle is not subtle, exactly, but it does raise issues that Americans were not keen to have seen by others. In its context of the mid-1950s there was a great controversy in Europe surrounding the film, Rock Around the Clock, which revealed the shift in America from an adult to a youth-oriented culture. And there are other Cold War films which should be studied in terms of their relationship to what we now call cultural imperialism."

"What really concerns me in all of this discussion," concluded Jowett, "is the question of how much of this really affected the public. We can talk all we want to about exposure to a message. But my training as a social scientist tells me we need to be very suspicious about what the so-called "reception" of these messages is. This vague term, "reception theory" should be replaced by "reception studies." We have yet to have a clear idea of how a message is likely to have somehow either influenced or not influenced people, and what is the process by which people are exposed to these images and subsequently react to them. Merely saying that there were a lot of movies and comic books with anti-Communist rhetoric doesn't mean that the public was buying in to all this." 


\section{THE COLD WAR ON TELEVISION}

The medium of television seized upon the Korean War as an immediate symptom and dramatic consequence of the Cold War. In the words of Bjorn Sorenssen of the University of Trondheim-NTNU, Norway, television coverage of Korea provided "an ominous example of what would happen if the war turned 'hot." A distinct departure from the traditional newsreel formats of NBC's Fox Movietone News and CBS's Telenews, which viewed the conflict in terms of inflammatory rhetoric and stentorian "voice of God" narration, were the See It Now broadcasts of Edward R. Murrow and Fred W. Friendly. Sorenssen demonstrated that two Korearelated broadcasts, in particular, the premiere program on 18 November 1951 and a special telecast entitled "Christmas in Korea 1952," presented a low-key, "first-person" view of the details of everyday life and the faces of individual soldiers - ideological issues were ignored - with an immediacy hitherto not possible in the new medium. Relating Murrow's style of presentation to the classical rhetorical styles of elocutio (the style of argument) and actio (the manner of delivery), Sorenssen argued that Murrow's great effectiveness as a communicator and the bond he was able to establish with the viewer lay in his rejecting the omniscient "voice-of-God" technique, and adopting the manner of "a fellow human being who offers his character up for judgment as the main guarantee for his argument"; moreover, he "gives an impression of speaking with the soldiers, not to them"; and he is "very obviously a man of the same world as his fellow men, and thus he can lay claim to speaking for them." While Murrow's achievement obviously derived from his radio experience, at the same time 
he was setting a standard for a new kind of television news coverage. In so doing, as Edward Bliss, Jr., noted in Now the News (1991) Murrow revealed "the nature of the war" better than anyone else at the time.

Was there a connection between the rise of commercial television and American anti-communist attitudes in the Cold War era.? In two presentations about American early 1950s television, David Weinstein, a documentary filmmaker, and Tom Doherty of Brandeis University, seemed to agree that blatantly anti-communist network programs of the 1940s and early 1950s played a significant part in forging a post-war anti-communist consensus in America. Weinstein's supporting evidence was persuasive: (1. Networks aired propagandistic messages in a desire to cater to insistently patriotic sponsors; (2. Programs reflected the fervent anti-communism of key executives, especially NBC's David Sarnoff; (3. Public affairs programs and government films were relatively cheap to produce; and (4. Networks were eager to avoid the imposition of federal regulatory measures. Moreover, all four networksABC, CBS, NBC, and Du Mont—were owned by corporations that were also government contractors in the early 1950s. Frequent customers of the networks were The Atomic Energy Commission and all branches of the military.

Du Mont especially stood to gain. A small firm in 1941, its business boomed as the nation mobilized for war. After turning over its factories for wartime radar equipment manufacturing, Du Mont positioned itself for post-war expansion by securing government support for the establishment of its experimental station, W3XWT (which later enabled it to operate commercial station WTTG-TV). In turn, as the Cold War intensified, Du Mont aired shows like Visit with the Armed Forces, 
Guide Right, and The Georgetown University Forum, which gave prominent anticommunist politicians and military officials a platform. At the same time, due to its government and military contracts, Du Mont profited from the military production which the Cold War demanded. Every year until it disbanded network operations in 1955, Du Mont made more money from its government contracts than from its broadcast operation. Thus, says Weinstein, while the connections at Du Mont between national defense and broadcasting were informal, it nonetheless was a company "which depended so heavily on military contracts that it could not afford to appear soft on Communism in front of the politicians and military officials living in Washington and watching WTTG-TV."

It was no surprise, therefore, that gavel-to-gavel coverage of the Army McCarthy Hearings, from April 27-June 17, 1954, was seen only on the ABC-Du Mont network. Otherwise, as Tom Doherty pointed out, the other networks broadcast only selected segments of the proceedings, while local station owners exercised considerable latitude in choosing what to air. As familiar as excerpts from the Hearings have become over the years - especially the climactic duel between McCarthy and Joseph Welch (“Senator, have you no shame?")—Doherty chose to emphasize a controversial sub-text that gradually emerged over the weeks and months. The possibility of a homosexual connection between Roy Cohn and serviceman G. David Schine (an allegation dramatized in the recent teleplay, Citizen Cohn, but denied by associates of Cohn) may not only have been a hidden motive behind the clash between McCarthy's Committee of Special Investigations and the Army, but, as 
COLD WAR/ Tibbetts/ 20

Doherty demonstrated, it might explain some of Cohn's obviously uncomfortable behavior, caught at key moments by the television cameras.

Both presenters admitted afterward that as important as the televising of the Army-McCarthy Hearings was in the history of television specifically and the Cold War generally, archival materials are unfortunately either scarce_only a few hours exist in the Library of Congress — or unavailable, since the complete coverage is locked away in vaults at CBS.

\section{THE BLACKLIST--General}

Among the many films seen at the Conference, one of the strangest was a direct result of the blacklist era. Cooper C. Graham, Curator of the Motion Picture Division of the Library of Congress, unearthed a vault print of MGM's The Hoaxters, a 1952 release that was subsequently nominated for an Oscar. Obviously patterned after an earlier MGM Clark Gable vehicle, The Hucksters (1948), the 36-minute film was produced by Dore Schary as an "answer" to criticism that he was soft on communism. Although Schary had signed the Waldorf Statement, it was well known that he had sympathized with members of the Hollywood Ten. Now, as Production Chief at MGM, he found it expedient to produce this film. Bracketed by scenes of a carnival barker selling the "snake oil" of communist propaganda, the film utilized graphics and footage from the Why We Fight series. As Graham noted, the establishment of parallel activities among the Nazis, Fascists, and Communists effectively erased any sense of their ideological differences. 
A particularly well-known document from the Blacklist era is $\underline{\text { Salt of the Earth }}$ (1954), Herbert Biberman's docu-drama about striking New Mexico miners protesting their deplorable working and living conditions. Blacklisted by the Hollywood studios, Biberman gained financing from the miners' union. According to a presentation by James J. Lorence, of the University of Wisconsin, when Congress was alerted to this supposedly "subversive" project, it grew alarmed that it might jeopardize Latin American relations. Subsequently, the American Legion protested it and many theaters and union projectionists who abided by the blacklist refused to screen it $\underline{\text { Salt of the }}$ Earth did not go into a general release until 1965.

One of the most interesting revelations to come out of the Conference was not from a presentation, but from an informal interview with Raymond Fielding of Florida State University. Fielding acknowledged that while everybody talks about the Blacklist, little direct evidence — call it a "smoking gun"—-has come to light. "I recall many years ago when Howard Suber of UCLA wrote his dissertation on the Hollywood Ten, he kept saying we have no 'smoking gun,' said Fielding. "We have nothing in writing that can pin the Blacklist on any executive. Well, about 18 years ago I had access to files at RKO Radio Pictures. I came upon a "smoking gun" for Howard Hughes. The only one we have. I have a copy of the documents, in which Mr. Hughes outlines how the studio will respond to the Communist threat. In effect, there would be no credits on films of workers who had failed to satisfy HUAC about their status; and such individuals would be thereafter fired and excluded from employment at the studio. Today, it is of great historical value. It runs for two or three pages. Perhaps I will write about it for the IAMHist Journal." 


\section{THE BLACKLIST_-Personal Testimonies}

Stephen Peet, former producer of BBC documentaries, and Augusta Perrin, former filmmaker for DEFA-Film Studios and GDR-Television, put individual faces to the otherwise murky story of blacklisting. In a poignant, moving presentation, Peet recounted how he found himself in a blacklist of sorts in Britain as a result of the defection in 1950 of his brother, John Peet, Chief of Reuters, Berlin. In a newsreel of his press conference, John declared: "I don't wish to serve the war mongers any longer. ... I'm sure there will come a time when all journalists can be decent and peaceful." Four years later Stephen learned that he was now under scrutiny because of John's defection, and as a consequence his initial attempts to join the BBC were unsuccessful In 1966 he learned with a certainty that he had been blacklisted. He took the matter to his local M.P., and for the next fourteen years until his retirement in 1980, he was able to work on the World in Action series and the Yesterday's Witness oral history series. Finally, in 1985 The Observer published an expose of the BBC blacklist, "The Blacklist in Room 105," which confirmed Peet's blacklisting. Ironically, Stephen was able to use the contact with his brother to make a film in East Germany for the World in Action series. "Life Behind the Wall" (1963) was the first film made in East Germany by a filmmaker from the West. During a visit to a documentary film festival in Leipzig in December of 1962 (just a year after the erection of the Berlin Wall), he got permission from the Minister of Culture to make a film on life in East Germany. With a 16mm Bolex camera, he traveled to Weimar, Erfurt, Eisenhuettenstadt, and Dresden to observe the lifestyles of ordinary citizens - a 
housewife, a dentist, a farmer, a soldier, a foundry worker, and a school girl. The film was produced for Granada Television. Ironically, it was refused entry a year later in the Leipzig Festival. Details linger in this writer's memory, a visit to Buchenwald, soldiers patrolling the border (their mundane activities counterpointed by the menacing strains of Stravinsky's Rite of Spring), a farmer's delighted response to the acquisition of a new tractor, children playing in a schoolyard.

Augusta Perrin brought her film, I'm a Negro, I'm an American, a documentary account of the life of Paul Robeson. It was produced by DEFA (Dokumentarfilme/Chronos-Film) in 1989. Robeson's passport had been withdrawn in the 1950s because of his purported communist sympathies. In effect, he was blacklisted, and his concertizing severely curtailed. This was meat for a procommunist tirade against capitalist repression. Repeatedly, the narrative voice insisted that the American "ruling class" was trying to kill him. Pete Seeger's harrowing firstperson account of the Peekskill riots on 4 September 1949 was used to confirm this. Ironically, during the making of this documentary, filmmaker Perrin herself suffered from a blacklist. Her name was taken off the Robeson film, which was finished by other hands. Thus, although it was marred by disjointed editing, poor film quality, and sloppy continuity, I'm a Negro, I'm an American remains today a testament to a dual censorship - the victimization of Robeson in America and the blacklisting of his chronicler, Augusta Perrin, in East Germany. 


\section{AMERICAN CONTROLS/ SURVEILLANCE OF HOLLYWOOD}

Some surprising revelations (to this observer at least) about FBI surveillance of Hollywood movies during 1942-1958 came from Tom Leitch, of the University of Delaware, and John Noakes, of Franklin and Marshall College, Lancaster PA. As early as the mid-1930s, J. Edgar Hoover had expressed misgivings about Hollywood movies, especially those like G-Men (1935) and Public Hero Number One (1935). At first he was primarily concerned with how they portrayed FBI agents as detective heroes. Not only did he fear they fueled the ambitions of super-patriotic amateur sleuths, but he may have felt they undermined his attempts to claim personal credit for all FBI activities. But weightier matters soon claimed Hoover's attention. Convinced that remarks made by a communist leader, Gregory Zinoviev, to the effect that the motion picture "can and must become a mighty weapon of Communist propaganda for the enlightenment of the widest working masses," Hoover shifted the FBI's view toward the supposed subversive content of movies.

During the first phase of its surveillance, 1942-1945, the Agency confined its overview to the purported communist political affiliations of movie makers. In his witty speech, "It's the Cold War, Stupid!" Tom Leitch of the University of Delaware, related a fascinating anecdote about what could happen to a filmmaker presuming to make a picture about international (read that: communistic) espionage. During the pre-production phase of Notorious (1945), Alfred Hitchcock made some inquiries into atomic bomb research. As a consequence, he was placed under government surveillance for months afterward. For a change, Hitch had good reason for his 
COLD WAR/ Tibbetts/ 25

lifelong paranoia of authority. Is the story true? Leitch doubts it. But it does point to the truth of the tensions that were present in and out of the industry during this period.

By 1945, the FBI's surveillance had expanded to the compilation of information on images, themes, and plots of suspected movies. Reviews in The Daily Worker were scanned, scripts were examined, and confidential information from informants was gathered. After 1947, with the HUAC hearings in session, the need for FBI undercover operations lessened considerably, and by 1958 the L.A. field office reported that communist infiltration of Hollywood "is practically non-existent at the present time." Subsequently, from 1947 to 1958, the FBI files on communist acctivity in Hollywood are primarily concerned with reports on movements in Hollywood to support the Hollywood Ten and oppose HUAC.

Citing findings collected in Dan Leab's Communist Activity in the Entertainment Industry: FBI Surveillance Files on Hollywood, 1942-1958 (1991), Noakes selected for discussion eight films that came under FBI opprobrium. The Best Years of Our Lives (1946), for example, was discredited because two cast members allegedly had communist ties and because scenes where characters criticize Russia are pointedly attacked in the script as tantamount to "anti-semitism, Jim Crowism, and $\mathrm{Ku}$ Kluxism." It's a Wonderful Life (1946) was “a rather obvious attempt to discredit bankers" and magnified the problems "of the so-called 'common man' in society." Other films, including Crossfire (1947) and Pride of the Marines (1945) allegedly belittled American institutions and glorified anti-American or pro-Communist values. Social ills like racial injustice, political corruption, and the post-war problems faced by 
COLD WAR/ Tibbetts/ 26

returning soldiers were, as Noakes claims, "recast by the FBI as criticisms of American institutions or advocacy of an alternative economic or political system."

Noakes concluded by noting the reasons the FBI did not pursue criminal prosecutions under the Smith Act, which had been passed by Congress in 1940, making it an offence to advocate the overthrow of the American Government: "To do so, the FBI would have had to risk exposing the informants and the investigative procedures the FBI employed in Hollywood." In addition, "the FBI ran the risk of looking foolish should the public reject their analysis of what constituted a subversive movie." Instead, the FBI laundered its surveillance information through HUAC. This was a boon to the publicity-hungry HUAC, who, according to Noakes, "had scheduled the hearings and had begun subpoenaing witnesses without any significant information on the presence of Communists in Hollywood."

\section{CONFERENCE PREMIERES AND PREVIEWS}

The Conference showcased several film and television premieres. The aforementioned Paul Robeson film by Augusta Perrin had never been seen in the West. Neither had Heiner Carow's seminal East German film, Coming Out (1989). In his screening of excerpts from the Carow film, one of the Ueberlaueferfilme ("transitional films") of the last years of DEFA, Ruediger Steinmetz of the University of Leipzig noted that it was the story of a high school teacher's coming to terms with his homosexuality. "Films like this marked a passage from one political system to another," explained Steinmetz. "Coming Out marked the first time male sex was depicted in the GDR. It was a plea for understanding and tolerance among viewers." 
It must be remembered that some of the images shown at the Conference, like the aforementioned television coverage of the Army-McCarthy Hearings, or excerpts from Sesame Street programs (courtesy of Robert W. Morrow of the University of Maryland) — so familiar to American audiences — were actually first-time experiences for many Conference attendees from the former Soviet-bloc countries. Indeed, the uncut kinescope footage from the 1954 Hearings was not only a revelation to those viewers but to the rest of us as well who never see more than the few scant seconds of the famous confrontation between Joseph Welch and Joseph McCarthy. (As for the

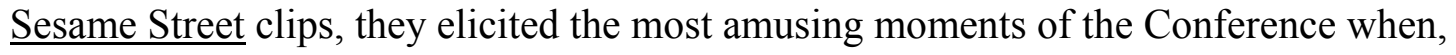
during an after-hours conversation outside the residence halls, Wilhelm van Kampen, Peter Kraemer, and Karston Fledelius debated the political and cultural significance of American pop culture figures like Barney, Daffy Duck, and Kermit the Frog. It was a wild and energetic debate, lubricated by several rounds of libations.)

There were "sneak previews" of two ambitious British documentary series soon to be seen on American television. People's Century is a joint production of the BBC and WGBH. The 26-episode program will be aired on PBS in the Spring of 1998. "I doubt if I ever work on anything this big again," said Christine Whittaker, Archive Producer of the Documentaries and History Department of BBC Television. "After all, when you think about it, you're talking about the whole of the century and the whole of the world. How can you ever do anything bigger than that? It's already being called the most ambitious series ever made. We made it for a mass audience and not for a group of scholars. We wanted it to be accessible." Of one of the two episodes shown at the Conference, "Boomtime," Whittaker added: "It's an optimistic story of 
COLD WAR/ Tibbetts/ 28

prosperity after the war. People started enjoying themselves again.” It was a delightful viewing, a needed leavening of the spirit after some of the heavier presentations of the day. Particularly amusing moments included newsreel footage of the introduction of Coca-Cola in Europe, television ads for cars (remember Dinah Shore's rousing anthem for Chevrolet?), optimistic views of the housing boom, and some poignant home movies.

Just as photography researchers increasingly are ransacking private snapshot collections for candid, unstudied views of domestic history, so too are archivists like Whittaker seeking out home movies. “Almost every episode of People’s Century has got home movies in it," she later told this writer. "In an episode called 'Brave New World,' we found several particularly exciting bits of home movies. One was an interview with Gayle Halvorsen, who was an American pilot in the Berlin Airlift, who figured quite prominently in the newsreels of that time. They called him the 'Chocolate Uncle,' because he used to drop sweets for the children of Berlin. Well, we found Halvorsen, and he happened to have had a $16 \mathrm{~mm}$ color camera with him during the Berlin Airlift. We even managed to trace one of the children he'd dropped sweets to. Another exciting home movie thing was from one of the Americans who had gone to the Moscow Trade Fair in the late 'fifties. He had a $16 \mathrm{~mm}$ movie camera with him, and he got footage of the Kruschev/Nixon 'kitchen debate.' No one had seen this stuff before we used it."

Taylor Downing, Managing Director of Flashback Television, London, brought advance glimpses of another major documentary series, Cold War. The project was commissioned by Turner Broadcasting. Turner, whose favorite television documentary 
series is World at War, contacted Jeremy Isaacs to produce a series documenting the Cold War years. Isaacs brought in Downing, and they formed a company to make 24 one-hour episodes. Composer Carl Davis, famous for his long association with series like World at War and the Kevin Brownlow Hollywood series, was called in to write the score. Cold War will air in Europe in the spring of 1998 and will come to America on CNN in the Fall of 1998. Downing reported that Turner has said he's so anxious to have it shown on Russian television that he'll give it away if necessary.

The excerpts Downing screened were Avid digital off-line cuts. Excerpts from the third episode, which dealt with the Truman Doctrine, included newsreel footage of the Christian Democrat victory over the Communists in Italy, aided by the newlyformed CIA. Scenes from the ninth episode, "The Wall," depicted the construction of the Berlin Wall in August 1961 and the tense stand-off between Soviet and American tanks on the Friedrichstrasse. From the eleventh episode, there were startling films from the age of Sputnik not seen before in the West—particularly, an appalling disaster in which an exploding missile engulfed scores of technicians in a flaming holocaust.

"We have an awesome responsibility to be taken seriously," declared Downing after the screening. In remarks obviously directed at a number of historians who had periodically expressed throughout the Conference their distrust of commercial television history documentaries, he continued: "But I believe there is now a generation of television historians prepared to maintain the highest possible standards." 
COLD WAR/ Tibbetts/ 30

\section{THE COLD WAR ABROAD}

Several presentations viewed the Cold War through British, Russian, Dutch, German, and French eyes. In "Enemies Without and Within,” Tony Marczan, of Hopwood Hall College, Lancashire, chronicled the "strenuous attempts" of the Thatcher government of the 1980 s to promote an anti-communist posture. [Although Marczan didn't note it, it's important to know that this was in decided contrast to earlier attitudes, by the Tories as much as by the Left, critical of the American witch hunts. As Geoffrey Wheatcroft has written in a recent article in the Times Literary Supplement, the anti-Communist hysteria typified by the McCarthy era and its subsequent blacklisting was seen in Britain "as hysterical over-reaction, and as a mistake worse than a crime." Americans were advised that the Communist menace "was best left to wither on the vine rather than nourished by persecution." [8] At any rate, Thatcher's new militancy was in accord with then-current books by General Sir John Hackett and President Richard M. Nixon that claimed the West "had been engaged in a losing battle with the USSR since 1945." Meanwhile, there was no support in Britain for the Soviet-imposed rule over Eastern Europe. Commercial television broadcast dramatizations of John le Carre's Tinker, Tailor, Soldier, Spy and $\underline{\text { Smiley's People, }}$ oppositional films like Anderzej Wajda's Man of Marble and Man of

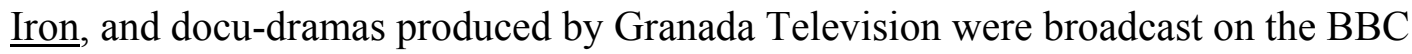
and ITV. Regarding the intense nuclear debate transpiring at this time, non-theatrical films like The Peace Game, produced by the Central Office of Information for the Ministry of Defence in 1982 - a response to Peter Watkin's anti-nuclear classic, The 
War Game - was part of a government-led campaign against the teaching of "peace studies." Present in many documentary films intended primarily for internal consumption and education distribution — especially to students in the 16-19 year age range - were claims that power stations were primarily for civil use, disguising the truth of the situation - "that the primary purpose of nuclear power stations was to provide highly irradiated uranium or uranium oxide fuel rods from which weapons grade plutonium could be extracted."

To be sure, continued Marczan, there was considerable dissent. The internal solidarity usually considered necessary to face a deadly external foe was never achieved. Oppositional television, especially drama, provided a counter to "the daily stridency of government rhetoric." Indeed, according to Marczan, "during a decade of ferocious internal antagonisms, the best of British TV drama sustained the soul of the nation." For example, there were numerous anti-nuclear statements in the 1980s, particularly in the BBC-produced teleplays like Airbase, $\underline{\mathrm{Z} \text { for Zachariah, and Threads }}$ (not to mention the importation of the American television drama, The Day After), the Channel Four-produced When the Wind Blows, an animated tale of the effects of nuclear war on a middle-aged couple, and Edge of Darkness, an expose of the use of a privatized nuclear processing facility toward militaristic ends. This latter film is, in Marczan's opinion, "the strongest statement of dissent during the decade."

Graham Roberts of the University of Leeds discussed British newspaper coverage of Gorbachev in the years 1985-1991. The press was mixed in their assessment of him. On the one hand, he was portrayed as an absolutist at the head of the Soviet Machine; on the other, as a Western-style politician. In a wry footnote, 
COLD WAR/ Tibbetts/ 32

Roberts showed several cartoon caricatures of Gorbachev from the British press. The clumsy likenesses, contended Roberts, symbolized the general confusion about the man.

The interpretation of the Cold War in France and Quebec was the subject of a paper by Susanne Langlois of McGill University, Montreal. Although the French Communist Party was strongly entrenched by the end of the war and in a position to be a strong partner in French post-war politics, it went into a decided decline in the ensuing decade. Part of its agenda had been the organizing of public protest to defend national film production against Hollywood influences, but this became increasingly difficult in the early 1950s with the increased interest by French critics and filmmakers in American cinema. While, unlike the situation in America and Britain, there was no wave of anti-communist films to come out of France at this time, a feature film was made that hailed the communist participation in the wartime Resistance. Normandie$\underline{\text { Niemen }}$ (1959-1960) was a Franco-Soviet production about a Free French flying squadron which fought on the Eastern front alongside Soviet pilots.

In Quebec, the Communist Party had, from 1921 until the end of World War II, been regarded more as an illegal party than as a regular partner in Canadian politics. Indeed, since 1937, the so-called "Padlock Law" had been adopted to prevent the screening of communist propaganda and the importation of Soviet cinema. Because The National Film Board of Canada, formed in 1939 and headquartered in Ottawa, was also suspected of communist associations, its films were banned-specifically, from Quebec schools_-by order of Premier Maurice Duplessis. Langlois pointed out, 
however, that despite these censorial restrictions, the Communist Party was in fact instrumental in stimulating several social reforms.

Sergei Drobashenko of Moscow State University documented instances of propaganda in Soviet-produced theatrical films in the 1950s and 1960s. "The capitalist world was no longer represented just as an anti-humane system," reported Drobashenko, but as a "treacherous and agressive" element in Western civilization, pursuing an agenda of "deceit and oppression of nations." Apart from the work of commercial filmmakers like A. Zarkhi (In the Name of Life, 1947) and F. Ermler (Great Force, 1950), who depicted the "decay" and "perfidy" of capitalism, and agitprop newsreels like News of the Day ("Against the Crimes of American Aggressors in Korea," "Hands off Lebanon, Iraq, Jordan," "Hands off China," etc.), there were scattered instances of filmmakers of considerable accomplishment and subtlety. For example, the work of Michael Romme was discussed, and excerpts from $\underline{\text { Murder in }}$

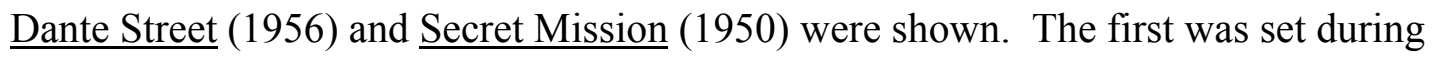
the French Resistance in 1940, and the second was set during the closing months of World War II. In Murder in Dante Street a mother, who is sympathetic to the communists, is betrayed by her Nazi collaborator son. In Secret Mission plans by a secret American delegation to negotiate the unilateral surrender of Germany (which would permit a united force to be subsequently directed against the Soviets) are foiled by Soviet intelligence officers in Berlin. What is noteworthy about the latter film, comments Drobashenko, is that Romme takes care to avoid mere rumor and innuendo and present the "conspiracy" as historical fact. According to Drobashenko, Romme eventually grew bitter about his participation in the Soviet propaganda machine and 
COLD WAR/ Tibbetts/ 34

suffered a creative crisis. "Thus," concluded Drobashenko, "we see one more

confirmation of the well-known truth that once an artist, however well-meaning, starts telling lies, his wisdom and talent fail him."

According to David J. Barnouw, of the Netherlands State Institute for War Documentation, the Anne Frank story become a political football in the early 1960s. The GDR-produced Ein Tagebuch fuer Anne Frank was banned by Dutch censors. The 20-minute documentary, directed by Joachim Hellwig, depicted the anti-Jewish raids on the Amsterdam Waterlooplein, the deportation train from the transit camp Westerbork to Auschwitz, and footage from Auschwitz and Bergen-Belsen. Problematic to the censors was the portrayal of the Federal Republic as a "direct, guilty descendant of the Hitler regime." Particularly troublesome were revelations that those involved in Anne Frank's incarceration and fate were still living comfortably in the Federal Republic. Although the prize-winning film garnered attention elsewhere, "its impact in the Netherlands was nil."

In one of only two Conference presentations regarding radio broadcasting in the Cold War - the other was Gary Edgerton's analysis of Ken Burns' Empire of the AirMichael Nelson, former general manager of Reuters, in his "War of the Black Heavens: The Battles of Western Broadcasting in the Cold War," recounted how the Cold War was fought by a consortium of Western broadcast entities, principally the BBC, Radio Free Europe, Radio Liberty, and the Voice of America. The attempts by the Soviets to thwart the broadcasts by jamming transmissions and stopping the mass production of short-wave radio receivers, claimed Nelson, were ineffective. "Pop music, talk shows, 
COLD WAR/ Tibbetts/ 35

news, and information about consumer goods all relayed a message of the good life, subtly undermining the values of the communist regimes."

Wilhelm van Kampen, Director of the Film Section, Landesbildstelle, Berlin, our host last year at the Berlin Conference and a past president of IAMHist, told the story of the Cold War and the Fall of the Berlin Wall through German eyes. The always amiable Wilhelm was a ubiquitous presence throughout the Conference; many of the films and telecasts he brought had never been seen in America. He provided an ongoing English translation to the Baumeister des Sozialismus ("Master Builder of Socialism: Walter Ulbricht"). In another presentation, "The Fall of the Wall," he analyzed GDR television coverage of the huge East Berlin rallies in November 1989, when some of the regime's most prominent intellectuals called for fundamental reform. Since the construction of the Berlin Wall in 1961, citizens of the GDR had been subjected to an intrusive and authoritarian police state. As late as 1988 hopes for the Wall's collapse and a German reunification were still dim. Everyone, including Chancellor Helmut Kohl, presumed that German unification was, at best, years in the future. The rapidity of ensuing events could not have been predicted: In May 1989 East German refugees were crossing to the west via the newly opened Hungarian border with Austria, or seeking refuge in the West German embassies in Hungary, Poland, and Czechoslovakia. Once this door was opened, East Germany lost the capacity to save itself with either repression or stringent economic reforms (remedies that might have increased even more the westward flight of its citizens). By November 9, when the East German authorities hastily announced the opening of its own frontiers and the Wall was overrun, an estimated 32,000 East Germans had already escaped. 
Van Kampen's excerpts from the "live" telecasts of political speeches and song, of the frenzied crowds impatient to cross through Checkpoint Charlie were riveting. Who can forget the moment when an excited woman kisses an East German border guard after he allows her to pass through to the Eastern sector to see her family? Indeed, one senses that at this moment the death sentence of the GDR was signed.

One of the most interesting, if less easily classifiable manifestations of the Cold War abroad occurred in 1958 in Brussels at the l'Exposition Universelle et Internationale de Bruxelles, better known as the Brussels World's Fair. James I. Deutsch, of the American Studies program of George Washington University, gave a political and social geometry lesson about the Cold War in "Circumscribing the Cold War: Cinematic Images of the U.S. at the 1958 World's Fair." Communism and capitalism found their respective architectural expressions at the Fair in the rectangle and the circle. The USSR pavilion was described in The New York Times Magazine as a "vast monolithic rectangular pavilion" which "has the soul of a warehouse." The American pavilion, by contrast, was circular, proclaimed by The Saturday Review as "the largest circular building in the world." This disparity of shapes suggests many things, explained Deutsch. On the one hand, it symbolized the Cold War stalement, the avoidance by the two super powers of "direct confrontation." On the other, the rigid angularities of the former seemed to symbolize a closed society dominated by the schematics of ideology and technology; and, conversely, the perfect balance of the latter symbolized the consensus of capitalism and the openness of the American way of life. Thus, while the Soviet exhibitions included Sputnik, the American displays featured continuous loops of film about everyday life. Subsidized by the Office of the 
U.S. Commissioner General and produced by Willard Van Dyke (with the assistance of Shirley Clarke and D.A. Pennybaker, among others), these 25 loops suggested, in the words of Robert H. Haddow's Pavilions of Plenty: Exhibiting American Culture, Abroad in the 1950s (1997), that America was "a supermarket. . of consumer goods" and not a nation dominated by the arms race."

\section{FIELD TRIPS}

Breaks in the long and intensive sessions were welcome. In addition to the latenight sessions at the nearby Fratelli's restaurant, there were three memorable excursions. A twilight picnic on the grounds of the Salisbury campus consisted of bratwurst, hamburgers, and fried chicken, garnished by the usual selection of drinks and desserts. Mid-summer temperatures were exceptionally mild, and the white picnic tables scattered under the greening trees made for a most agreeable setting. Later, busses took us the NASA Museum, where members of the German contingent drily noted the absence in the displays of German scientists and German technology. A walking tour of the Chinkoteaque Wildlife Preserve, followed by a few hours at the ocean front, afforded ample opportunities for hiking boots, bird-watching, and sunbathing. One prominent member of IAMHist, whose name discretion bids me withhold (although his initials are "C" and "F"), was observed disporting himself shamelessly about in the surf. The local press, not to mention curious IAMHist conferees, were astonished at the sight and moved in for a closer look.

The last day of the Conference, 31 July 1997, was spent in Washington, D.C. at the National Archives (College Park) and the Library of Congress. At the Archives 
auditorium, after greetings by our hosts, David Kepley, Chief of the Archives' Motion Picture, Sound, and Video Branch, and William Murphy, Specialist in Audiovisual Archives, Nontextual Archives Division, we settled in to a program of USIA documentaries concerning the Cold War. Most of us had never seen these films. Until recently, government policy decreed that USIA films could not be shown in the United States (an exception was Bruce Herschenson's Years of Lightning, Day of Drums, about which more will be said later). The first film on the program, the aforementioned The Wall (1963) — produced to commemorate the first anniversary of the building of the Berlin Wall — was a poetic evocation of the hardships and dangers the repressive climate held for those separated from their families and for those, like the unfortunate Peter Fechta, who was killed as he tried to escape to the West. The Death of Imre Nagy (1959) profiled the career of the man who led Hungary through a period of relative moderation in the mid-1950s. After the Budapest riots were crushed by the Soviets, Nagy was seized, secretly tried, and executed in 1958. $\underline{\text { Czechoslovakia }}$ (1969), which won an Oscar in 1970 for Best Documentary Short Subject, encapsulated the span of Czech history from 1918-1968 in a scant fifteen minutes.

Afterward, Kepley, Murphy, and a third guide, Les Waffin, conducted tours of the facility. Erected in 1993, Archives II, as it is called, is the largest archives building in the world. Together with the historic National Archives Building in Washington, D.C., the new facility assists the National Archives in the Washington area in acquiring, preserving, and making available to the public records of historical and cultural value. Its staff of 600 personnel, assisted by 200 contract support workers, administer the Research Room operations, state-of-the art labs, lecture rooms, storage 
vaults, a day-care center, presently stores two million square feet of archival material. Archives II has all special media materials, including motion pictures, still pictures, sound recordings, maps, architectural drawings, aerial photography, and electronic data relating to such matters as the military, foreign relations, commerce, labor, transportation, fiscal policy, energy, and social issues. The audiovisual collection alone consists of more than 150,000 reels of film, 160,000 sound recordings, and a rapidly growing collection of more than 20,000 videotapes. In addition to USIA films, and Universal newsreels are Voice of America broadcasts, short-wave broadcasts from foreign countries, Civil Defense agency films, interviews for CBS/Longine Wittnauer, etc.

The ease of access, not to mention the general permission granted to those who wish to copy or dub audiovisual materials, caused more than one European archivist's jaw to drop. I was particularly impressed when, at my request, David Kepley located a print of Walt Disney’s notorious World War II feature, $\underline{\text { Victory Through Air Power }}$ (1943) for screening. It's there, waiting for me, the next time I'm in Washington. ... An hour later we were ensconced in the Mary Pickford Theater in the Library of Congress, Motion Picture Section. Our hosts, Cooper C. Graham, Acquisitions Specialist, and Patrick Laughney, Curator of the Pickford Theater, screened excerpts from several classic Hollywood "anti-Red" films. Even though many of us had seen

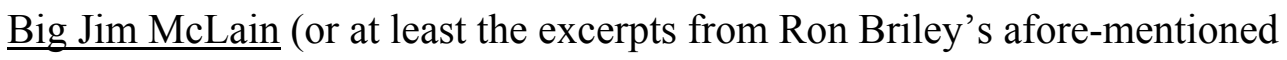
presentation), it was a revelation to see Big John sweeping up commie trash in a crisp, beautiful $35 \mathrm{~mm}$ print. Several films long regarded as curiosa of the Cold War period, notably I Was a Communist for the FBI (1951) and My Son John (1952), as well as 
COLD WAR/ Tibbetts/ 40

underrated classics like Elia Kazan's Man on a Tightrope (1953) were well served in arresting, thought-provoking excerpts. Afterward, the conferees gathered in the foyer of the Pickford Theater for refreshments (which, unfortunately, proved to be pretty meager fare, considering that IAMHist shelled out $\$ 750$ for the event).

\section{INTIMATE HISTORIES}

Meanwhile, away from the Conference rooms, a quieter and more intimate kind of historical chronicle unfolded. During breaks, meals, and late-night relaxation at Fratelli's, attendees exchanged their own personal histories. Peter Kraemer of Keele University, Staffordshire, and Ruediger Steinmetz, of Leipzig University, discovered a commonality in their boyhood experiences in Germany. The Cold War years of the ' 60 s held for them little political or dramatic connotations, just the day-to-day business of growing up. Kraemer's youth was spent in Steinbach, north of Frankfurt, near Giessen. While his mother, a single parent, ran the local supermarket, he and his schoolmates led normal lives, except they were always reminded in school that Soviet tanks could come across the border at any moment. The American military presence at the supply base in Giessen was also vaguely menacing. Peter remembers the rumbling sounds of truck convoys passing through on maneuvers, when some of the G.I.'s threw them chocolates from the backs of trucks. For him and his friends, who had never seen people of color, the African American soldiers, particularly, had a vaguely exotic aspect.

Steinmetz grew up in Goettingen, 140 miles south of Hamburg, about ten miles from the eastern border. His father was a teacher, his mother a housewife. He grew up 
COLD WAR/ Tibbetts/ 41

listening to radio broadcasts from GDR radio and television. Sirens sounded through the town on a monthly basis. A stream of Fluchtlinger, refugees, from Prussia

constantly passed through the area. Although he recalls the day his father took him to the border for a first-hand glimpse, he didn't actually see any Russian troops until he went to Berlin as a soldier.

\section{VARIATIONS ON HISTORY:}

At the heart of these discussions, formal and intimate, was the complicated issue of the relationships among media, history, memory, and bias: How is historical information processed and transformed through cultural reception, memory, and the new electronics technology? What happens when texts are disseminated into popular culture and transformed by viewers into something that has meaning to them-even when this happens to the detriment of historical truth or accuracy? Perhaps, history after all, as Pierre Sorlin once wrote, is "no more than a useful device to speak of the present time." [9]

Foregrounding these issues were several presentations dealing with what Steve Anderson in his talk, entitled "Loafing in the Garden of Knowledge" [a quotation from Nietzsche's Of the Use and Abuse of History] called "anti-realist" or "transgressive" history films. This burgeoning field of study began, for this writer at least, with volumes edited and/or written by John E. O’Connor and Martin A. Jackson (American History/American Film, 1979), Pierre Sorlin (The Film in History: Restaging the Past, 1980), and Peter C. Rollins (Hollywood As Historian, 1983); and has been taken up most recently in Robert Brent Toplin's History by Hollywood (1996) and three 
anthologies edited by Leger Grindon (Shadows on the Past, 1994), Robert Rosenstone (Revisioning History, 1995), and Vivian Sobchack (The Persistence of History, 1996) The opposition of fact and fiction, a founding presupposition of Western historiography, has been called into question in modernist and post-modernist practice. Like the fall of the Berlin Wall, the taboo against mixing fact with fiction has been abolished. New genres, in both written and visual form have appeared, bearing names like "para-historical representation," "docu-drama," "infotainment, "historical metafiction," etc.; and are typified by works as various as Truman Capote's $\underline{\text { In Cold }}$ Blood (1965), the television series, Roots (1977), and Oliver Stone's JFK (1991).

Whereas the traditional paradigm of the history-novel/film held that the "interference" between an imaginary tale of romance and a set of historical events was mediated by the presumed capacity of the reader to distinguish between real and imaginary events, the New History, as Hayden White states, "puts in abeyance the distinction between the real and imaginary"; everything is presented "as if it were of the same ontological order, both real and imaginary - realistically imaginary or imaginarily real. ..." (White in The Persistence of History, 19) Add to this the processes of viewer memory and bias and it is manifestly apparent that the notion of historical "facts" as the basis for "meaning" becomes clouded indeed. "What is at issue here," writes White, "is not the facts of the matter regarding such events but the different possible meanings that such facts can be construed as bearing." [italics mine]

Such developments have created yet another "cold war" tension. On one side of the cultural divide are the traditionalists who insist that the territories of fact and 
fiction are clearly demarcated and labeled; on the other side are the New Historians, who permit those boundaries to blur and disappear. Nicholas Cull, of the University of Birmingham, and Gary Edgerton, of Old Dominion University, illustrated the dispute in two documentaries, respectively, Bruce Herschenson's classic USIA documentary, Years of Lightning, Day of Drums (1964) and Ken Burns' Empire of the Air (1992).

Herschenson's film, the first feature of the USIA, was described by Cull as not only an obituary of a fallen President, and a key text of Kennedy's life, but “a superb example of how America fought the Cold War with the film medium." Herschenson, who was convinced that a documentary could be as vibrant and dramatic as any fiction film, deliberately wrought distortions in his Kennedy portrait to enhance its personal appeal and ideological position. The most striking departure from the factual record, in Cull's view, was the way that Herschenson juxtaposed footage of a civil rights march on Washington to a soundtrack of a Kennedy speech on civil rights issues. The fact is, Kennedy never spoke at this rally. But even the alert, informed viewer can be fooled. Although after the presentation Cull came under attack from Richard C. Raack for seeming to approve of Herschenson's bit of historical sleight-of-hand, Cull responded that perhaps there was a larger truth at issue here, notably, that Kennedy's sympathy and support of the civil rights movement was felt to be an important tool in the arsenal of the propaganda battles of the Cold War.

Edgerton, an authority on Ken Burns, noted that Burns used Empire of the Air as a tool not so much for a technological history of radio, but as a weapon for his own personal attack on corrupt capitalism and the takeover of individual ambition and enterprise by ruthless corporations. The real hero of the film, inventor/entrepreneur E. 
H. Armstrong, whose innovations included the regenerator, the superheterodyne, and frequency modulation, is another in a series of rugged individualist/visionaries celebrated elsewhere in Burns - engineer Washington Roebling (The Brooklyn Bridge, 1982), populist politician Huey Long (Huey Long, 1986), the sculptor Bartholdi (The Statue of Liberty, 1985), black ballplayers Satchell Paige and Kurt Flood (Baseball, 1995), and religious leader Anna Lee (The Shakers, 1985). Armstrong alone among his competitors, which included the ruthless David Sarnoff and the deluded Lee DeForest, is romanticized as a kind of Tom Swift figure, a wizard of electronics who tilts his lance against the corrupt forces that in the end will destroy him. Burns' frequent use of images of high towers — on which the swashbuckling young Armstrong clambers, above which a grim-faced Sarnoff presides over his empire in Rockefeller Center, and from which a suicidal Armstrong plunges to his death in 1954 establishes a central metaphor of vaulting ambition and tragic failure. "I am playing with history," Burns admitted to this writer in an interview a few years ago. "I'm an amateur historian, but most of all, I'm a filmmaker, an artist, trying to manipulate image and sound to create feelings in people. I happen to work in American history and use its stories. The art relies in how I relate to it. The subject is almost accidental." [10] Several presentations of theatrically-released biopics and social history films brought these issues into the commercial arena. Andrea Staskowski, of Nassau

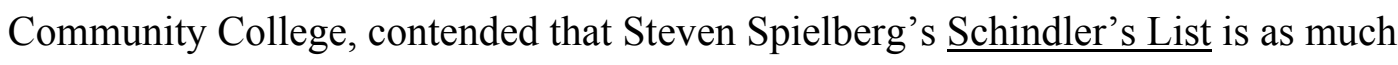
about Spielberg's ego and career building as it is about the historical Holocaust. She pointed to the film's dedication to Steve Ross. Who is Steve Ross? she asked rhetorically. Why should a movie of this monumental seriousness be dedicated to the 
late CEO of Time/Warner? Could it be that there is an implied connection among Ross, Spielberg, and Schindler himself - as entrepreneurs and/or opportunists? In short, what is this movie really about? [It's interesting to note that Joseph McBride's

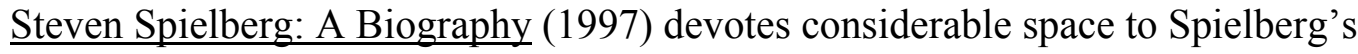
relationship to Ross, who apparently became something of a mentor and example to him. "I always told Steve that if he was fifteen years younger, I'd cast him as Schindler," Spielberg is quoted as saying. "After I met Steve, I went from being a miser to a philanthropist, because I knew him, because that's what he showed me to do." [11]

In "Liszting to Left and Right," John C. Tibbetts, of the University of Kansas, screened excerpts from eight movies purporting to depict the life of composer/piano virtuoso Franz Liszt. No consistent portrait emerged of music history's most flamboyant and provocative figure - who has "appeared" in more theatrical films than any other composer. Rather, the "truth" of Liszt lay scattered among the wildly varied (and contradictory) biases and agendas of each of the filmmakers, which included Max Ophuls, Clarence Brown, James Lapine, and Ken Russell, among others. He became, in effect, a "rorschach" test for each of the filmmakers, each viewing him from his own social/cultural context.

Albert J. Griffith, of Our Lady of the Lake University, discussed the links between memory and history in John Boorman's autobiographical World War II film, Hope and Glory (1987). History, in this case, was viewed sidelong, as it were, and from a distance. This was a small boy's war, where the horrors of the day were inflected - and sometimes deflected — by the accumulations of over half a century of 
COLD WAR/ Tibbetts/ 46

memory and nostalgia. Past was prologue to the man and artist John Boorman has become.

Steve Anderson, of the University of Southern California, directed our gaze to the tube. Anderson explored the ways "anti-realist" histories - $\underline{\text { Star Trek, Dark Skies, }}$ Quantum Leap — have renarrativized historical events and presented alternative versions of them in the light of present-day perspectives. For example, through "time warps" and "space worm-holes" the crew of the Enterprise continually stumbled across "alternative worlds" — variations, as it were, on accepted views of the Roman Empire, the England of Robin Hood, Chicago in the 1930s, etc. These worlds interfaced with the "present tense" of the astronauts (which, of course, meant the “present day" of 1968). Dark Skies brought Cold War paranoia - and, by implication, the 1950s cycle of "invader" movies — into our own present. The series (now cancelled), suggested that a conspiracy among extraterrestrials, who visited the earth fifty years ago, has shaped the subsequent events of our recent past and present. It was a cabal of aliens, for example, who were responsible for those seminal historical events like the Cuban Missile Crisis and the assassinations of JFK and Martin Luther King. "The show is interesting in its conception of history as being infinitely rewritable," declared Anderson, "and in its willingness to superimpose this preposterous narrative on virtually any historical event or person." Anderson concluded that this "playful," or "transgressive" history, while frowned upon in traditional academic-historical discourse, "may allow us to glimpse some of the desires, projections, and personal idiosyncracies that operate in film and TV histories when they're cut loose from 
COLD WAR/ Tibbetts/ 47

historical conventions and standards." History, ultimately, may be more the product of competing narratives rather than any one "official" story.

\section{CONCLUSION}

Beyond the many contradictions, confrontations, and revisionisms of the IAMHist/ Literature/Film Association Cold War Conference, however, one fact is indisputable, and that is the untiring efforts of the always amiable and helpful James M. Welsh, who, with the staunch support of his wife, Anne, and Peter Lev of Towson University, organized and conducted the event. But if the image of Jim - this final image from the heart of the Cold War revisionings - is blurred, it's because Jim moved too fast for the camera shutter. He was everywhere, introducing panelists and speakers, driving people back and forth from the airport, manning the registration table, arranging the food service and distributing the room keys, acting as guide on the tour busses, and, in general, constantly trouble-shooting the myriads of problems that inevitably occur.

At the core of our Cold War preoccupations, in other words, it was nice to know there was the steady beating of a warm heart.

John C. Tibbetts 


\section{NOTES}

[1] Walter Benjamin, "Theses on the Philosophy of History," in Hannah Arendt, Ed., Illuminations (New York, 1977), p. 255.

[2] Even the film itself has acquired a mysterious anonymity. According to the notes provided by the Archives, the film's credits are missing.

[3] George Kennan, At a Century's Ending: Reflections, 1982-1995 (New York, 1996). Indeed, Kennan calls the twentieth century "a tragic one in the history of European (including American) civilization" (1). It was Kennan who in 1946 defined the doctrine calling for the "containment" of the Soviet Union; however, he quickly rejected it, and for half a century has contended that nuclear weapons - and modern weapons in general - have ceased to be effective instruments of national policy.

[4] Quoted in Geoffrey Wheatcroft, "The Kremlin's Greatest Asset," Times Literary Supplement (6 June 1997), p. 10.

[5] In the words of co-directors Charlotte Crabtree and Gary B. Nash, "this project sought to develop broad national consensus for what constitutes excellence in the teaching and learning of history in the nation's schools." See Charlotte Crabtree and Gary B. Nash, National Standards for United States History: Exploring the American Experience (University of California, 1994), p. iii.

[6] Ronald Radosh, "What Agent 58 Achieved," Times Literary Supplement, (11 July 1997), p. 28.

[7] See J. Hoberman, “Red Musicals," Film Comment (July-August 1997), pp. 32-38.

[8] Geoffrey Wheatcroft, “The Kremlin's Greatest Asset,” p. 10.

[9] Pierre Sorlin, The Film in History: Restaging the Past (Totowa, N.J., 1980), p. 208.

[10] Interview with the author, 3-4 August 1994.

[11] Joseph McBride, Steven Spielberg: A Biography (New York, 1997), pp. 429-430. 
INTERVIEWS FROM THE “COLD WAR AND MEDIA” IAMHIST CONFERENCE Conducted by John C. Tibbetts

Christine Whittaker, Archive Producer, BBC Documentaries and History Department.

(Let's begin with your work on People's Century)

I started working on People's Century in 1992. Peter Pagnamente, the executive producer, had already done about a year's development work with historical advisers and researchers. I came on board along with a production manager to try and get the thing going. We were co-producing with WGBH. My job, really, was to coordinate, oversee, and produce, all the archive research. We made 18 of the 26 programs (WGBH made eight). Each is 53 minutes long. There are at least 30 minutes of archive in each program. We're talking about a lot of footage.

I doubt if I ever work on anything this big again. After all, when you think about it, you're talking about the whole of the century and the whole of the world. How can you ever do anything bigger than that? In that sense, it's been called the most ambitious series ever made. We made it for a mass audience and not for a group of scholars. We wanted it to be accessible. "Boomtime," particularly, has a "happy" message to it. It's an optimistic story of prosperity after the war. People started enjoying themselves again. Of course, when the oil shock came, things started going wrong. It was a particularly fun program.

(I noticed that you use home movies. . .)

Almost every episode has got home movies in it. What has happened is, that archive researchers are talking to each other a lot more. I started doing archive research 25 years ago, and I always worked on big series. In those days, if you did international research, you might go to the National Archives or the Library of Congress in Washington, D.C. We feel we are in heaven when we come there, because of all this public domain material. We don't have anything like the Freedom of Information Act, you see. Or you might go to Fox Movietone in New York. And if you were really adventurous, you might go to the Bundesarchive in Germany. But now, every researcher is expected to pull in footage from throughout the world. And it's much easier to do that.

As far as home movies are concerned, you simply advertise. With a lot of home movies, you find the people and they have film. In "Brave New World" we had two exciting bits of home movies in that. There was an interview with Gayle Halvorsen, who was an American pilot in the Berlin Airlift. He figured quite prominently in the newsreels of that time. They called him the "Chocolate Uncle," because he used to drop sweets for the children of Berlin. We found him, and he happened to have had a $16 \mathrm{~mm}$ color camera, and he had done his own filming of the 
Berlin Airlift. And we managed to trace one of the children he'd dropped sweets to. The other exciting home movie thing was the Moscow Trade Fair in the late 'fifties. There was a famous moment when Kruschev and Nixon had the Kitchen Debate. We interviewed one of the Americans at the Fair, and he had a $16 \mathrm{~mm}$ home movie camera. So we got extra footage of Kruschev and Nixon that no one had ever seen before.

The most exciting home movies I ever found was for a piece about Nancy Astor, an American, the first woman M.P. to sit in the House of Commons. She was married to Waldorf Astor. They lived in a stately home called Clifton, in Britain, a meeting place for literary and political luminaries. They used to have these huge house parties. I placed an advert in the Daily Telegraph asking if anyone had any footage of Nancy Astor. Normally, you get letters, and when you follow them up, it turns out somebody has a copy of a Pathe newsreel, or something. But this guy rung up and said he used to be the electrician at Clifton. And when Clifton was sold-it's now a National Trust — he bid for a film projector he knew was there. He also said that with the projector were two cardboard boxes of film. He asked me if I wanted to have a look. Naturally, I said yes, please. I went down and it was the whole home movie collection of the Astor family. Some of the Astor children, now grown, came down to see it with us. There were shots from as far back as the 1920s. There were views of Macmillan, George Bernard Shaw. It was absolutely incredible.

(Is there a moment of discovery in your archive researchings that you particularly remember?)

It sounds ridiculous, but what you have are high spots of things you particularly love. On this series, things in the program I adore are some wonderful color footage of France in 1912. A Gaumont process, a three-lens color system, almost a precursor of Technicolor. The quality was unbelievable, wonderful footage of people at the beach. That was used in our first program. There was also some early film that didn't end up in the program. I think it was from 1903, a static camera in Paris on one of the boulevards, was positioned outside a public convenience. It was just an uncut film of men going in and out.

(I assume that the more unposed and uncalculated the film footage is, the more value it has for you.)

Well it does to me, it interests me. However, in a series like People's Century, each kind of film has its own purpose. Film that is edited and which has commentary, or a newsreel, has a value of its own, too. It's quite difficult to use such footage, though, because it's very different from professionally-shot material. It's got its own pacing, which means you have to use it complete and not intercut it with other material. It doesn't work. Now, of course, every other person has a video camera.

(Are there materials that are particularly hard to locate, for whatever reason?)

Well, I hate to say it—it's terrible, it's awful—but the thing people look for the most is Holocaust material. We did a program for People's Century called "Master Race," and it won the International Emmy; and we had new material in there. In fact, I've been seeing some material recently from a researcher who spent two years touring 
the world. He's found some extraordinary material. It's awful, it's terrible. Why should we want to see any more?

(Talk about your background and what has best suited you for this job?)

You know, I really don't know. I was a linguist, I did languages at university, the University of Leeds (where Phil Taylor teaches). But I wasn't an historian. I'm not even a particularly visual person. I left university with a degree in French and German. I wanted to be a translator but couldn't find a job. I joined the BBC as a production assistant working in the Overseas Broadcasting section to French Canada. And I then moved to television and became a researcher within the next year and a half. I started doing some film research and I found I was good at it. I left to have my first child. When I came back in 1981 to work on a series called All Our Working $\underline{\text { Lives, }}$ which was a big history of British industrial life, things went from there. I may be the longest serving and most experienced film researcher in Britain, actually. For some reason, I've got a very, very good visual memory. I don't know why, I just do. I've also got a logical mind, I can make connections among all kinds of film sources, and I can fit things together from this place and that place. It's the sort of thing you discover on the job. I'm not an historian. The history I know I've learned on the job.

(Do you belong to a coterie of film researchers, some sort of organization of archivists like you?)

There's now a group called FOCAL, which is a relatively recent organization. It has a quarterly journal. It has archivists as members, too. There's an American Archivists Association. But in fact, it's a small world. The people all know each other. I've know Jerry for years. I've just co-written with Prudence Arndt, who was the Chief Film Reseacher on the Chief Film Reseacher on the ABC Century Series, an article about a big catalogue put together in 1987 by Rick Prelinger which really changed our lives. He was a film collector who'd been collecting industrial films for many, many years. His book was called The Guide to North American Film and Video Sources. There's been an update since then; and they're about to do a 1997 volume.

(How has the advent of video tape affected your research?)

It has created problems. The best and easiest time to research is the golden age of the newsreels from the late twenties to the mid-sixties. There were four newsreels producing several editions per week, in which the major news events appeared. Then came a sort of dead period in the ' $70 \mathrm{~s}$. Now, there is so much material, it makes it more difficult to focus. The worst time is in the fifties, live television, before videotape was invented. The quality of telerecordings, or kinescopes, is very, very poor. Newsfilm used in the 1970s is pretty awful, too. The color is appalling and the color is boring. It was shot on reversal stock, and it's faded very badly. And because there's no negative, there's not much you can do with it. As for two-inch videotape, what can I tell you? It's a nightmare. It's awful. You can't play it back at speed. The BBC Library has been doing an extensive preservation program and it's transferred two-inch tapes onto a digital format. There are still all the one-inch tapes. I've worked a lot with video tape. For People's Century we've done rough-cuts off-lined on Betacam SP. We actually cut on Beta, which we then put on Avid. Then we fine-cut 
on Avid. We did that because the Avid machines then didn't have a long enough memory for the amount of material we had to deal with. Now, you'd go straight on to Avid.

Taylor Downing. Television producer of factual programs in Britain. 18 July.

(Let's talk about the creation of your company, Flashback Television.)

I guess it begins with the creation of Channel Four in 1982. It was not committed to taking programs not from the $\mathrm{BCl}$ or $\mathrm{BBC}$ (the largest production outfut in the U.K.), or the companies making up the ITV Network (Thames, Granada, Yorkshire, London Weekend, Scottish Television, HTV, etc.). These have traditionally been the basis from which programs have been drawn. When Channel Four established, it said it sought alternative programming from independent companies. That led to a renaissance of small, independent production companies. I had spent most of my career in the ITV companies like Thames, working with Kevin Brownlow, David Gill, and Jeremy Isaacs. I left the ITV world in 1982 to make a 20-part history series called Flashback (hence our name). Other like companies followed suit. In 1990 the Broadcasting Act formalized the system whereby 25 percent of all broadcast programs had to be made by independent companies. The BBC is now required by law to take 25 percent of its output from independent producers. Likewise, ITV. Channel Four takes almost 100 percent of its programming from independent producers. Now there are about 100 independent companies. Once they would have made mostly documentaries; but now they are making programs in every programming genre.

The story of Flashback is representative. Its core activity is the making of history programs, but it also produces drama documentaries, arts documentaries, lifestyle programs, etc. It is one of the few companies in continuous existence since 1982 and has produced nearly 400 separate documentary programs. To navigate the stormy waters of production over that period of time, one needs to have a reasonable diversification of programming and producers. We employ between 20-30 people, with many freelancers on a particular project.

(How did you get involved in The Cold War?)

Cold War was commissioned by Turner Broadcasting, who specifically wanted Jeremy Isaacs to make the series. Turner was in Leningrad when he hatched the idea to do it. His favorite television program had been World at War. Jeremy, who worked initially at Flashback, then decided to form his own company to be the vehicle to make the programs. Cold War now comprises 24 one-hour programs. We originally planned twenty episodes. A chronological order was decided upon. Carl Davis was commissioned to compose the music. Each episode would be self-contained. I've been working on it since 1995 and will deliver it in the spring of 1998, and it will be first transmitted in America on CNN in the Fall of '98. In Britain it will be shown on the BBC2. Turner has said he wants it shown on Russian television, even if he has to give away the program. 
[The Cold War Conference enjoyed a World Premiere, as it were. Downing screened Avid digital off-line cuts. Excerpts were from the third episode, which dealt with the Truman Doctrine and the subsequent debate. The Christian Democrat victory over the Communists in Italy. Aid from the newly-formed CIA, which had been a result of the National Security Act. From the ninth episode, entitled "The Wall," were events from the construction of the Berlin Wall in August 1961, from barbed wire to the wall itself. The tank stand-off at Friedrichstrasse. From the eleventh episode, there were startling films of the age of Sputnik, of Soviet missile disasters where a flaming holocaust engulfed crewmen.]

It seems that we made this series at a most opportune time. The window that opened worldwide for our access to archives is now already closing.

We have an awesome responsibility to be taken seriously, but I believe there is now a generation of television historians prepared to maintain the highest possible standards. 
Raymond Fielding. 27 July.

I'm Dean of the School of Motion Picture, Television, and Recording Arts at Florida State University. I'm a longtime member of IAMHist, almost since the beginning when I hosted the Journal in Houston, where I was Director of the School of Communication.

(Could a Conference like this have been done very satisfyingly before the Wall fell?)

Well, walls keep going up and coming down. There's always a war of some sort. It's the role of the communication theorist and historian to analyze the way in which wars are covered while they are transpiring and then analyze and interpret them after the fact, when you have to put the pieces together and make sense of them.

(Do we have hindsight now on the Cold War?)

When I was at Houston, we used to host and supervise the Conference on Freedom of Mass Communication, held at Valley Forge each year. The last one we put on was just before the Wall fell down. I recall at that time that just about every speaker said we had put ourselves out of business. The irony was that we might not have another meeting like this. The USIA representative said that, unbelievably, the Soviets had allowed them to open a bureau in Moscow. Well, that was a sign of things to come. What a splendid opportunity for the academic scholar to come together with practitioners at such a time.

The scholar plays a lot of roles in society. And he had better be prepared to do a lot of broken-field running. Some of us who come to these conferences are also educators, and we must attend to training a new generation of citizens and students. We have an especially important obligation to bring back some insights to them. My counterpart at UCLA, Gil Cates - both he and I are active in the Motion Picture Academy-was quoted as saying that 70 percent of the new directors in the entertainment industry was trained in a film school. This is a sobering thought, wondering who we're turning out after more than seventy years of communications education. We've been in business long enough, collectively, that we can ask ourselves whether out mentors and whether we in turn have done a good job in preparing the historical practitioner. This conference for me is not merely a scholar's delight but an educators' obligation.

(Any questions on your mind as you come here?)

As a matter of fact, I was going to prepare a paper myself. A perfect opportunity for it. One of the issues one deals with is the growing paranoia of the postWar years. In the communication industry there was great distress with the Blacklist and so forth. That was very unpleasant and very scary and worth restudying. What did Plato say — man will be dead before he achieves peace. In any event, we all know there 
was a Blacklist that affected many people. I recall many years ago when Howard Suber of UCLA wrote his dissertation on the Hollywood Ten, he kept saying we have no "smoking gun." We have nothing in writing that can pin the Blacklist on any executive. Well, about 18 years ago I had access to files at RKO Radio Pictures. I came upon a "smoking gun" for Howard Hughes. The only one we have. I have a copy of the documents, in which Mr. Hughes brings his authority to bear upon the Communist threat. It's a memorandum created by his secretary in which he outlines how the studio will respond to the Communist threat, to the effect there will be no credits on films of workers who had failed to satisfy HUAC about their status. It dealt with the firing of these individuals and the exclusion of them from employment at the studio. Today, it is of great historical value. It runs for two or three pages. Perhaps I will write about it for the Journal. Things of this sort you can build upon, which would lead to a discussion of Hughes and his place in society and in the film world in particular.

(We most associate with you the newsreel. Is that topic a part of this conference?)

Oh, yeah. There are several papers on the subjects of the newsreel archive, which is the foundation for any research on on compilage films. I have written in some length about the need for credibility of compilage films. I have made many films like this myself-I'll work as a filmmaker the first half of the week; then as a scholar in the second, at which point I'll be appalled at what I did!

(Are there still materials about the Cold War coming to light?)

Years ago at a conference in Rochester the late Hal Potter, who had been head of Fox Movietone Newsreels for many years, said they had just discovered a wonderful collection of footage they didn't know they had on Richard Nixon. Now the older collections which I've worked with-Pathe, Paramount, Universal—when I was running a consulting firm in Houston are now fairly well known. An East German collection of Fox Movietones has just been reclaimed. Steve Davidson in Miama at the Wolfson Foundation has had access to independent television station archives. I brought one of these to the Library of Congress several years ago when I was living in Philadelphia. The process took about three years. In time it will be indexed and catalogued. A splendid collection, about three million feet - every format, beginning with film, both color and black-and-white, single system, double-system, two-inch quad, one-inch and all the rest. All from 1949 onward. Covering not only the city of Philadelphia, but also regional, national, and international news. What is happening, as Steve is discovering, is that there are materials we don't know about.

Some archives are now collecting home movies. Which have another purpose, a kind of anthropological study of social moreys. They are very revealing. Often times, amateur footage is of substantial historical value as well.

(Am I right to be alarmed that video tape has documented a whole generation?)

Yes, video tape is doomed and so are the machines that run it. We're in terrible danger of losing our own generation, i.e., the last thirty-five years or so. Recently, the Library of Congress held a panel of testimonies in Los Angeles from television executives and engineering heads, as well as from librarians and archivists from public and private sectors. The picture is very grim, because, in part, the machines are wearing out. There aren't very many two-inch quad machines any more. When they 
go, that's the end of it. You can't rebuild them, in most cases. When they go, that's the end of the material. And of course, video tape is a terrible medium; it has no archival integrity. The Library of Congress hearings are just coming out now, and it is hoped they might generate Congressional support for funding for the non-profit archives, which need financial help the most. Digital transfer is about the only process that will help now, but that goes on to tape, too. Plus, the transfer is only as good as the original tape. The problem is the staggering amount of material. I played a role in the recent sale of the Grinberg Library in New York and Los Angeles, which, until fairly recently was also the archive for ABC Television News. The amount of material that comes in each month boggles the mind. Only about ten percent of it is indexed; the rest goes out to a warehouse in Long Island somewhere.

I just finished a two-year commission, a joint-production of the $\mathrm{BBC}$ and the CBC, a six-part, six-hour series on the history of television news. The first two hours, which was my part (based on my two books), reveals that the visual materials from early years are superior in quality to the video materials from more recent decades. Now so much is on tape.

One of the proposals made by the Librarian of Congress was to standardize just one video format for the next fifty years. At least the machinery would continue to be manufactured during that time. The executive was very sympathetic, but he said it wouldn't work. He said it is the nature of engineers to perpetually improve and change the technology. Nothing would stop that. He couldn't see a cessation of new product for archival purposes.

We have some public support for the salvation of commercial feature films. But the dilemma of video goes largely unnoted. The sheer amount of material is too overwhelming, I suppose.

In November I'll go to the AMIA (Association of Moving Image Archivists). They are 90 percent concerned with the access, use, and preservation of the artifact. That will be in Bethesda. That's the place to go for new information. Another organization, the International Federation of Film and Television Archives, sometimes meets jointly with AMIA. The technology needed to preserve video and other materials is in place, for the most part, the problem is the cost.

Not many young people consider preservation as a viable career goal. Some do as they get into graduate studies. We have just acquired an archivist for a study collection of a million feet of $35 \mathrm{~mm}$ feature films. But filmmakers and consumers are not very concerned. It's our fault, to an extent. We've spent a hundred years of motion pictures and fifty years of television in training the public to look at these media as consumables. Now what will undoubtedly come out of the laboratories in time will be new storage systems which will allow for reliable safety and which can handle the sheer quantity of materials. One manufacturer, I'm told, now has a server, a giant hard disc about the size of a refrigerator, which can hold a hundred thousand titles. This will be a real breakthrough for instantaneous access and storage of television programming. It's also a fabulous new approach to archiving. The speed at which transfers are being achieved is increasing.

We talk a lot about how media historians have to be flexible, wary of received opinion, open to new information and new source materials, prepared to review their conclusions and so forth. Well, archivists need to be flexible, too. It places another 
emphasis on the intellectual and scholastic foundations of scholarship itself and archival procedures, which if they are well grounded and well studied, will serve the archivist and the historian. Historians have always had to be quick on their feet. And so now must the archivist.

Garth Jowett, University of Houston Nicholas Cull, University of Birmingham

(What are some Cold War/media issues that need to be addressed?)

(Jowett) To a large extent, it's been done to death by academics in recent years who've reassessed the Cold War and how it's been portrayed. On the other hand, the general public still sees the 1950s as a happy, complacent atmosphere. And there are current politicians who keep referring to the ' 50 s as a wonderful time that we've lost and have to strive for and regain. In the last ten years, there's been an attempt by academics to rectify that image, to explain to Americans that we didn't really have such a complacent time in the 1950s after all. The "Leave It to Beaver" image is constantly raised. That image has become so ingrained in America, that the Cleaver family has come to represent some sort of reality. Whereas, there was a greater percentage of people on welfare, a terrible situation for women in terms of employment and divorce, a rampant racism, etc. In other words, although academics are constantly revising the " $50 \mathrm{~s}$, the general public has not yet bought in to that concept.

(Cull) I think one of the things we have to look at in a conference like is to look beyond the sort of analysis that has happened so far, like the analysis of motion pictures in the 1950s. We're up to our ears with readings of Invasion of the Body

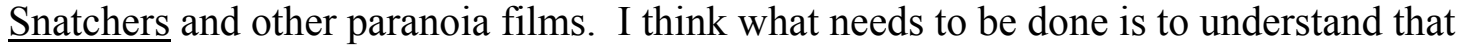
the media was an active player in the Cold War; to study the strategic use of radio, of Voice of America and Radio Free Europe; and also the use of propaganda films to affirm American foreign policy. That hasn't been done properly. We wouldn't consider thinking about film in the 1930s without also considering the documentary films used to promote the New Deal. But we approach the Cold War without serious study of film propaganda as an element in American strategy overseas.

(Jowett) Americans don't like to believe that the country propagandizes. It you examine propaganda in any detail in this country, the notion that the government is actively engaged in the active manipulations of people's cognitions is something that is simply laughable to most people. When we do have revelations, like the attempt to bomb Colonel Kadaffi, we have a brief flurry of excitement. We say that we didn't realize our country did that; and then people back off. What happens in the 1950s is that the government and Hollywood was actively propagandizing. Either we know that, or we don't seem to care very much.

(Accepted opinion is that Hollywood films didn't really have Communist propaganda in them.)

(Jowett) I think that a lot of filmmakers in the 1945-early ' 50 s period were responding to World War II and to the perceived power of the film in World War II to create some kind of shift in public attitudes. In other words, they were actively propagandizing, and if you read some of the literature at the time by the filmmakers, 
what they were saying was they used movies for good during the War; and now let's try to continue that impetus and use movies for good after the War. Pictures like Gentleman's Agreement and Crossfire were a continuation of the use of the power of the movies, and not an attempt to create an ideological shift. But the sensitivity in America on the part of politicians was that any criticism of society was considered to be Communist. A movie like The Grapes of Wrath was not allowed to be shown in Europe after the War, because it was perceived to be anti-American and proCommunist.

(Cull) There's a great story connected with The Grapes of Wrath. Stalin wanted to show it in the Soviet Union as an example of how bad capitalism was. But audiences responded, marveling how many trucks those peasants had! Great!

(Jowett) Yes, the Russians were amazed that people as poor as the Joads could own a truck! And so Stalin's plan backfired. Now, there's an article that deserves to be done, to examine the list of films that were not to be shown in Europe after the Liberation. Apocryphal as it may be, the story is the Europeans asked for two things from the American occupying forces. The first was food; the second was movies. I don't know exactly how true that is. But certainly the Americans had to draw up a list of what movies could and could not be shown. The OWI made the decisions, especially regarding problem films, like those involving anti-semitism or race relations, etc. When you jump forward to the mid-1950s, you have that famous incident where Clare Booth Luce as Ambassador to Italy, had Blackboard Jungle withdrawn from the Venice Film Festival, where it had won the prize. It was a great controversy, because she didn't want it shown overseas as an example of what American juvenile delinquency was like.

(Cull) The connection between USIA and the Venice Film Festival is sustained throughout the Cold War period. The director of USIA would go to Venice with American films and preside over their screening to European critics; and they'd decide which ones best represented the United States.

(Jowett) We have to go beyond seeking out the obvious political allegories in '50s films. It's like shooting ducks when you start picking on things like Invasion of the Body Snatchers. Not only has it been done to death, but it can be read in many different ways. There are other films that depict American society in more subtle ways. Blackboard Jungle is not subtle, exactly, but it does raise issues that Americans were not keen to have seen by others. In its context of the mid-1950s I was just told that there's great controversy in Europe surrounding the film, Rock Around the Clock That film is such an icon of the shift in American culture from an adult to a youthoriented culture. Apparently that film caused quite a stir in Europe as well. There are other Cold War films which should be studies that relate to what we now call cultural imperialism.

(Cull) Maybe it's time to move beyond the term, "Cold War," which in itself is a construction of American culture. Rather, talk about the projection of American power, culturally and militarily, during this period. That provides more continuity than the term "Cold War," which artificially frames us between 1946 and 1989. Really, this is a story that is rooted far earlier and ends far later. If we focus on the Cold War in a very rigid sense, we lose a lot of the story. My concern is that some of our interests get too tied to political aspects of the Cold War, which are artificially constructed anyway. 
We tend to think, Oh wasn't it terrible what happened to Liberals during the Cold War without considering the wider contexts and empathizing with the fear of Communism at the time and the Soviet Threat. There's little acknowledgment that there actually might have been a Soviet threat which, if unchecked would do terrible things to Hungarians, Czechs, and Poles.

(The generation growing up today finds it increasingly difficult to relate to the subject, now that the Soviet Union has fallen.)

(Jowett) When I show several of these films in propaganda classes, it's difficult for me to convince students that the Soviet threat was a very real one. And when you shows them documentaries on Soviet propaganda, they tend to find them laughable. At the same time, I ask them to go home and ask their parents and grandparents what it was like to live in the 1950s. They come back with remarkable stories about the kind of paranoia they lived under; that they were indeed fearful they might not wake up in the morning. That kind of paranoia was being distilled and instilled in America. Then we discuss the "duck and cover" thing. Clearly, throwing yourself under a desk was not going to save you from nuclear destruction. So the question becomes, why were they pushing that. What they were doing was trying to promote the illusion that the government cared and that you could be protected (which in fact, you couldn't!).

(Cull) Another issue that comes up is how unempowered people felt about the Cold War, and how difficult it was to participate in it. A lot of things that happen in Cold War and in Cold War culture is this promotion of the illusion of participation. "Duck and Cover" was one thing. But also, Cold War culture enables you the sense of participation. Novelists like John LeCarre provide such a way. Puzzling through the intrigues of his novels enabled you to feel you were participating vicariously in this struggle.

(Jowett) There's an interesting parallel in the great propaganda posters of World War One and World War Two. My students are always amazed when I show them things like variations on "Zip Your Lip." They ask me if there was really this serious Fifth Column threat. The answer is, absolutely not. It wasn't as if everybody were running around talking about troop movements and so forth. It was a way of getting you to participate in the war effort as a civilian.

(Cull) Therefore, audience awareness of the audience of these films is important. Films that were sent overseas likewise had the impact of involving those viewers with Americans.

(Jowett) We also have a parallel with the end of World War One with the decimation of the European film industry. During the 1920s, before sound came in, it was virtually dominated by the American film industry. We can trace the domination of Europe by American popular culture from then, and from the subsequent events that followed World War II. As much as might hate this, as much as there might be a lot of rhetoric about American cultural imperialism, the fact is that American popular culture is becoming increasingly dominant because of new technologies like television and satellites.

(Cull) At the same time, American popular culture has been very inclusive. Hollywood has also bought the best talent that's out there and absorbed it.

(Jowett) This is where the reality and the perception don't match. The perception is, these are basically American ideas being pushed off onto the world 
public. Where, in fact, increasingly, for survival, popular culture has to be internationalist in its approach to succeed. Here in America, we forget this. Look at our Monday morning habit of examining the morning newspapers for the movie box scores. Films are now rated on the basis of how much they pulled in last weekend, ignoring the fact that a film like Judge Dredd will have the international box office as its savior, and not that of the United States. Sixty percent of its boxoffice may be pulled in outside of the United States. So films are made with that larger boxoffice in mind-

(Cull) - Which explains all the violence and explosions that are there, because they don't need translation. International teams of filmmakers now come to bear on individual American productions. Independence Day had a German writer-American nationalism as only a German could imagine it!

(Jowett) What really concerns me in all of this discussion is how much of this really affected the public? We can talk all we want to about exposure to a message. But my training as a social scientist tells me we need to be very suspicious about what the so-called "reception" of these messages is. This vague term, "reception theory" should be replaced by "reception studies." We have yet to have a clear idea of how a message is likely to have somehow either influenced or not influenced people, and what is the process by which people are exposed to these images and subsequently react to them. Merely saying that there were a lot of movies and comic books with anti-Communist rhetoric doesn't mean that the public was buying in to all this.

(Meanwhile, the emphasis seems to be on the American contexts of the Cold War. What about other countries?)

(Jowett) I think that a conference like this inevitably has a concentration on blacklisting in Britain and America. But the notion that American popular culture was dominantly pushing this thing is a misnomer. I do not know that much about the history of Russian filmmaking in the Soviet block countries in this period as a countermeasure. Of course, we always have this image of heavy propagandistic film, which we know historically that audiences have never enjoyed. Subtle propaganda is much more effective than a heavy-handed one.

(Cull) I know the Soviets had stage shows satirizing western Cold War film. There was a James Bond stage show in 1965, where Bond would appear on stage to be attacked from various people, including a KGB agent emerging from the toilet!

(Was there an equivalent to HUAC in any other countries?)

(Jowett) That's a good question. Other American allies in NATO were subjected to similar kinds of suspicions in the sense that the American control of NATO extended that sort of investigation. But that's as far as it went. The HUAC thing is so difficult to get a handle on in terms of its influence. We can document precisely the things that happened in the hearings themselves, but the ethos that they created in America is one that is very difficult to fully assess.

(Cull) HUAC was public theater. The point was that it provided a public forum for these tensions to be worked out between new migrants and older Americans. The whole McCarthy thing was the revenge upon the older Americans by the newer Americans, the revenge of Irish and Catholic Americans on the establishment. To go to the Alger Hiss case, there were significant moments where on the witness stand the 
questions relate to his education and note is taken of his Oxford accent and his wearing of striped pants - things seen as "un-American," culturally - are tied to the extreme Liberal politics.

(Jowett) What the historian Richard Hofstadter called the "paranoid style" of American conservatism. That still is true today. There is a definitely an antiintellectual bias to American conservatism. Anyone perceived as a thinker rather than a doer is considered to be suspicious. We can go back a long way in American cultural history to perceive the whole role of culture as possessing a "feminist" kind of trait, one that puts you under suspicion - the "Ichabod Crane" phenomenon, if you willwhere being a teacher and a thinker, as opposed to a tinkerer and a doer, is considered suspect. So, when people thought and wrote about ideas, they were immediately suspicious. HUAC works out a lot of those tensions. The role of the intellectual came under enormous fire. Why the movies? That, I think, is clear. Hollywood provided the best public whipping boy in terms of publicity for HUAC. They very clearly went after Hollywood, even at a time when Hollywood was in decline in terms of its influence in America. To attack the great icons of Hollywood was a guarantee of frontpage news. They could have gone elsewhere, but they were guaranteed their image as "cleansers" by going after Hollywood.

(Jowett) Beginning with Hollywood in 1938, when HUAC first comes on the scene. Gerald P. Nye, in his very famous speech in 1939, talks about propagandizing at the boxoffice. He refers to "Europeans," a term he uses constantly, which is a thinly disguised anti-semitic notion. What resulted after that speech was an infamous, and rather hilarious Inter-State Commerce Committee hearing on propagandizing in the motion picture industry in 1940. That hearing was adjourned in October 1941 to reconvene in January 1942. But on December the $8^{\text {th }}, 1941$, the Committee was "permanently disbanded" because of Pearl Harbor. Those were fascinating hearings. What they did was highlight all the fears of conservative Americans about the potential power of the movies.

(Cull) What came out of those hearing was also that none of the representatives chairing the hearings had actually seen any of the movies they were talking about. Jack Warner asked them if they had seen the films, and the answer was no.

(It seems that few popular histories are telling this story to the general reader.)

(Jowett) When you say "popular history," academics cringe when you declare anything to be "popular." As an editor of a series of film books, I find that young scholars are discouraged from doing lengthy histories. Secondly, there is a feelingand I think this is totally wrong - that doing a lengthy history is a kind of easy way out; that what you need to do is spend five years of your life writing some sort of excruciating monograph on the presentation of pumpkin seeds in Invasion of the Body Snatchers as opposed to doing a large-scale history. There are some interesting academic politics here. One of them is that many are actively discouraged from taking on larger works. During the pre-tenure period, they're told to "get it out there" and "write as many works as you can." And for God's sake, don't take on something that will need several years, even though it might be an important contribution. Academic politics is actually intercepting the sort of work that should be done. As an editor, I'm constantly soliciting projects that get a scholar enthused, until he or she is discouraged by their department chair. For example, I've been turned down by five scholars on the 
subject of doing a book on "Feminism and Popular Culture," because their department chairs warn that it's too long, that it's a mistake to write a book for a series, that it's too controversial (and would annoy other, more senior scholars), and so forth. There's a lot of academic politics involved in why some books don't get done. Large-scale books are considered to be something you do in the year just before you retire!

(Cull) I can see what Garth is talking about. But personally, I have no trouble plugging away at my history of the United States Information Agency, from 1953 to the present. It's going to take me at least five years. And that's not considering some obstructions out there that might delay me. On the other hand, I already have tenure! I admit I might not have taken on such a project before I got tenure. But I would disagree with Garth to the extent that there is a crying need for more articles that do take on quite specific subjects. For example, you don't see so many things on just single films any more. That really go in to a single film, look at its script, examine its publicity, and assess the transformations of the script on the way to the screen.

(Jowett) I guess I am getting curmudgeonly. But I get annoyed at too much of what I read. I call it "feet on the desk" scholarship. I notice that a lot of young scholars don't do the leg work of actually trying to seek out the original source materials, go into the files. It's much easier to screen the film fifty times in your office than it is to go look up the production files.

(Cull) This coincides with certain critical ideas that the author's intentions have no significance. This gives a scholar the perfect theoretical justification for not going to the private papers of the author or the filmmaker, of not looking at studio and/or governmental records. Too much of what passes for today's scholarship leans in this direction.

(Jowett) I must say that Nicholas' book on the USIA promises to be quite significant. As somebody who's spent the last twenty years looking at the history of propaganda, I think that this is a major effort. The USIA has tended to do "self history" in the past. If you rely on the public histories, you get an increasingly distorted history of the Agency. You have to spend years going through all the documents, which they've never released.

(Cull) Here at the Conference I'll analyze the USIA's first feature, Years of Lightning, Day of Drums, as not only an obituary of a fallen President, and a key text of Kennedy's life, but as an example of how America fought the Cold War with the film medium. Although filmmaker Bruce Herschenson was a conservative, he was a favorite of Kennedy's. He was convinced that a documentary could be as vibrant and dramatic as any fiction film. Of course, for years this particular film, like other USIA films, could not be shown in the United States, due to USIA policy. But an Act of Congress in 1966 allowed it to be shown here. More recently, President Clinton has acted to allow any USIA film twelve or more years old to be shown to American scholars.

John C. Tibbetts 
COLD WAR/ Tibbetts/ 63

\section{SOME RECENT COLD WAR-RELATED PUBLICATIONS}

Redeeming the Wasteland: Television Documentary and Cold War Politics, by Michael Curtin (1995)

A five-year period of New Frontier documentaries on the three networks, ABC's Bell and Howell Close-Up!, NBC White Paper, and CBS Reports.

Documentary felt to be an effective countering of Soviet propaganda and a means to "foster an imagined comradeship among citizens of the free world."

Hollywood's Other Blacklist, by Mike Nielsen and Gene Mailes (1995)

IATSE blacklisting after 1945.

Man Without a Face, by Anne McElvoy (1997)

"Spymaster" General Markus Wolf, one of the founders of the Die Hauptverwaltung Aufklaerung (HVA), the Main Intelligence Directorate of the GDR ("If I go down in espionage history, it may well be for perfecting the use of sex in spying.")

Operation Solo, by John Barron (1997)

The story of Morris Childs, a respected member of the CPUSA, their liaison with the Kremlin leadership for 25 years, who actually was one of the most successful intelligence agents for the United States in the Cold War era.. 
Confessions of a Spy, by Pete Earley (1997)

The fifth and latest book about Aldrich Ames, a CIA worker turned spy for the KGB in the latter years of the Cold War.

Korea's Place in the Sun, by Bruce Cumings (1997)

The controversial book deals, in part, with his thesis that the American intrusion into the wreckage left by forty years of Japanese rule — which had already precipitated a barely contained civil war between North and South by 1948 - helped perpetuate and worsen the subsequent Korean War.

Gorbachev and His Revolution, by Mark Galeotti (1997)

Contrasts the forces for change that Gorbachev catalysed and unleashed within a stagnating and moribund Soviet regime.

Inside Out, by Walter Bernstein (1996)

A memoir by a blacklisted Hollywood writier.

McCarthyism, edited by Albert Fried (1997)

A compilation about the so-called "Great American Red Scare."

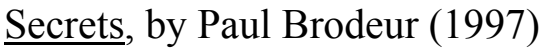

A former New Yorker staff writer broods over the last forty years, the paranoid atmosphere that led to CIA's assassination plots against Castro, Nasser, and Sukarno; the trumped-up pretext for the Vietnam War, the FBI's wiretapping of Martin Luther King, Jr; the Watergate and Iran-contra scandals; the superfluousness of the invasions of Panama and Iraq.

We Now Know: Rethinking Cold War History, by John Lewis Gaddis (1997)

The dean of Cold War historians surveys new scholarship and confirms that it was Stalin who was primarily responsible for Cold War escalations. "Once it was clear his state would survive the way, then it looks. . . clear that there was going to be a cold war whatever the West did." Has this book come out too soon, though? There's still too many newly unearthed documents to sift through. ...

Germany Unified and Europe Transformed: A Study in Statecraft, by Philip Zelikow and Condoleezza Rice 1997)

Claimed that the reunification of Germany within NATO was a triumph of American diplomacy.

Inside the Kremlin's Cold War, by Vladislav Zubok and Constantine Pleshakov (1997) 
One of the first systematic attempts to sift through newly released Soviet documents. It concludes that while it was Stalin whose miscalculations started the Cold War, American responsibility in continuing the struggle after Stalin's death cannot be discounted.

Age of Delerium, David Satter (1996)

A former Moscow correspondent argues that Communism was destined to fail by reason of its materialistic interpretation of mankind. It was brute social engineering. Glasnost, originally designed as another instrument of control, in actuality, through its publicizing of Stalinist crimes, revealed Communism itself as a historic mistake.

Reflections of a Cold Warrior: From Yalta to the Bay of Pigs, by Richard M. Bissell, Jr. (1997)

Revisionist views of two of the CIA's purported triumphs, overthrowing the Mossadegh regime in Iran in 1953 and the Arbenz regime in Guatemala in 1954. Indeed, the latter operation helped to mislead the CIA into backing the Bay of Pigs disaster in Cuba.

The Ghosts of Berlin: Confronting German History in the Urban Landscape, by Brian Ladd (1997)

History of the city.

Whittaker Chambers: A Biography, by Sam Tanenhaus (1997)

Hiss was guilty and Chambers was telling the truth.

The Last Division: A History of Berlin, 1945-1989, by AnnTusa (1997)

Critical of the "ineffectual and timorous behavior of the Western Powers"

toward the Soviets in the Cold War. Western strategy was essentially defensive: "This meant that the Western allies might have been prepared to fight to maintain their hold on their sectors of Berlin, but not to prevent the Soviets from doing what they wanted in the East."

Dissolution: The Crisis of Communism and the End of East Germany, by Charles S. Maier (1997)

As opposed to The Last Division, Maier contends that in the long run the Western powers' patience paid off. Three changes--the steady decline in ideological commitment, the deterioration of the economy, the upheavals in European Communism that followed Mikhail Gorbacherv's efforts to reform the Soviet Union. Of the three, the collapse of the Communist bloc seems by far the most significant. A scholarly analysis of how and why the Communist regime in East Germany came apart and disappeared. A narrative of the last days of the GDR, not just the general failure of Communism, but as a reflection of a profound shift of late $20^{\text {th }}$ century society towards complexity, in which the simple models of central control of mid-century East and 
West simply failed. One particular problem was the GDR's inflexibility regarding economic policy.

\section{COLD WAR}

XVIIth IAMHist Conference: The Cold War

25-31 July 1997

Salisbury State University

It is not judgement that is difficult; it is understanding.

In 1947 the National Security Act established the CIA, whose mission was to contend with the Soviet enemy. Since 1989 the Cold War came to an end, a string of authoritarian regimes in Central Europe collapsed, the GDR was absorbed into the FRG and the two Germanys were reunited into a sovereign state, the Soviet empire imploded, and Communism, as an ideology of government, disappeared.

Issues include the relationship between fact and fiction, journalism and entertainment, indoctrination and education.

How do we measure the parameters of the Cold War? The question was voiced repeatedly. What sort of yardstick is needed, emotional, political, cultural, historical? Did it begin with the conclusion of World War II, as some voices asserted, or farther back in time with the Russian Revolution? Did it end with the fall of the Berlin Wall 
or with the collapse of Soviet Russia? Indeed, has it ended at all? Or perhaps its span can be calculated in a matter of just two decades. Consider--In Augusta Perrin's Paul Robeson's documentary, folk singer/ activist Pete Seeger dodges thrown stones during a riot in Peekskill in the mid-1950s. But in Robert W. Morrow's presentation on Sesame Street, Seeger appears as a special guest with the Muppets. -------Tom Leitch cited Hitchcock

\section{VARIATIONS ON HISTORY:}

Steve Anderson of the University of Southern California talked about "AntiRealist" history. Taking liberties with historical fact. Television series like Star Trek, Dark Skies, Quantum Leap, present their own versions of historical events. "History as we know it is a lie," says a character in Dark Skies. In that series archival footage is blended with fictional action to create alternative history. It suggests that a conspiracy among extraterrestrials has shaped the events of our recent past and present. This is history disengaged from reality, suggesting the infinitude of historical possibility.

Barbara Margolis presented her award-winning 1987 film, Are We Winning, Mommy? It was a seven-year project. Although it was shown in international festivals, it was not shown on PBS. The purview extends from the Yalta Conference and ends with the space race. Mixed in with the amusing clips from Cold-War television series, like The Hunter and excerpts from other television dramas, was the implication that Russian saber-rattling and expansionist actions was caused by American aggressive posturing. R.C. Raack bitterly attacked this agenda as fraudulent history. In his view the film was leftist propaganda.

Similarly, Nicholas Cull also came under attack during his presentation of Bruce Herschenson's Years of Lightning, Day of Drums. "Here at the Conference I'll analyze the USIA's first feature, Years of Lightning, Day of Drums, as not only an obituary of a fallen President, and a key text of Kennedy's life, but as an example of how America fought the Cold War with the film medium. Although filmmaker Bruce Herschenson was a conservative, he was a favorite of Kennedy's. He was convinced that a documentary could be as vibrant and dramatic as any fiction film. Of course, for years this particular film, like other USIA films, could not be shown in the United States, due to USIA policy. But an Act of Congress in 1966 allowed it to be shown here. More recently, President Clinton has acted to allow any USIA film twelve or more years old to be shown to American scholars. In his presentation, Cull pointed out the distortions in the Kennedy obituary: For example, the footage of the march on Washington where crowd reactions to speakers is seen against Kennedy's speech on civil rights. So you have the impression that Kennedy addressed the march on Washington. Such distortions drew outrage from R.C. Raack.

Cooper Graham, Curator of the Motion Picture Division of the Library of Congress, presented one of the most curious, and relatively unknown, films of the Blacklist period, an MGM film called The Hoaxters. Released in December 1952 (and subsequently nominated for an Oscar), and obviously derived from an earlier MGM feature, The Hucksters, the 36-minute film was produced by Dore Schary as an 
"answer" to criticism that he was soft on communism. Although Schary had signed the Waldorf Statement, it was well known that he had sympathized with members of the Hollywood Ten. Now, as Production Chief at MGM, he found it expedient to produce this film. Bracketed by scenes of a carnival barker selling the "snake oil" of communist propaganda, the film utilized graphics and footage from the Why We Fight series. The establishment of parallels of activities among the Nazis, Fascists, and Communists effectively erased any sense of their ideological differences.

All these examples point to the abuse of documentary materials, a point decried by many historians throughout the conference. "Too many actualities have been taken out of context and deliberately used to convey fictions," declared Taylor Downing, a managing director of Flashback Television. "Intercutting archive film with reconstructions is especially egregious. We have an awesome responsibility to be taken seriously. Those of us who regard ourselves as television historians must be prepared to avoid these traps and maintain the highest possible standards."

Philosophical Roots of Cold War Films

The anti-utopian political consensus of the Cold War. Shannon Mader of the University of Southern California suggested that a profound irony dominated post-war culture, namely, that communism and democracy were both rooted in the same philosophical and utopian ground; and that nuclear weaponry, while perhaps prolonging the Cold War, ultimately forced both sides to temper their moral and political absolutes, as was seen in the series of confrontations in Cuba, Berlin, Korea, Vietnam, and Afghanistan. America, for example, may have been uneasy about the wielding of power, but it did so out of its certainty of moral right.

\section{HOLLYWOOD AND THE RED MENACE}

As the political climate continually shifted and changed in the years spanning the 1917 Revolution to the height of World War II, so too did Hollywood's portrayal of the Soviets. Michael S. Shull, of the Washington Center, tracked these changing images in a series of films: Dangerous Hours (1920) depicted revolutionary Reds as rampaging beasts; Clear All Wires (1932), presented a more accommodating ' 30 s view

of Soviets as loveable eccentrics and crackpots; and Comrade X (1940), on the heels of the Nazi-Soviet Pact, viewed them as vicious Nazi collaborators.

David Wilt's "Uncle Joe Joins the Family" discussed yet another shift in Hollywood's portrayal of the Soviet Union. In an attempt to win audience support toward the Soviet participation in the Allied cause, Russian people were portrayed in a sympathetic light. Hollywood's strategy included avoiding references to pre-War Soviet activities, especially the Nazi-Soviet Pact, and ignoring ideological discussions. Accordingly, the words "Red," "Soviet," "and communism" were replaced by the generic term, "Russian". In his survey of ninety Hollywood wartime films, Wilt claims that Stalin's name was mentioned only eighteen times. In general, his image was white-washed in Foreign Agent, Days of Glory, The North Star, Song of Russia, The Boy from Stalingrad, and Mission to Moscow. In films like The North Star, Russians 
were portrayed as living in picturesque villages. They were happy villagers, people capable of individual actions, attending church ceremonies, and working closely with the Allies. They were generally recast in the American image, a fact confirmed in the casting of Americans in Russian roles.

In the 1950s, as Ron Briley, of Sandia Preparatory School in Albuquerque, demonstrated, John Wayne's Big Jim McLain set the standard for anti-communist pictures. Ironically, Wayne was not a devout anti-communist until around 1948, when he became President of the Committee for the Preservation of American Ideals. McLain's targeting of communists who hid behind the First Amendment found a parallel in Wayne's later The Green Berets (1968), when Vietnam war protestors were singled out for scorn.

Ironically, as Shannon Mader of the University of Southern California suggests, the simplistic views of these films are at variance with prevailing social attitudes. She objects to certain conclusions in the work of Thomas Schatz and Robert Ray, who held that the classical Hollywood cinema functioned to "resolve or reconcile ideological and cultural contradictions." If true of the post-war films, she declares, they are in opposition to societal consensus "that social conflicts and ideological contradictions were inevitable and ultimately unsoluble [italics mine]." She claims that films by John Ford, especially Fort Apache (1947), and Alfred Hitchcock, particularly Lifeboat (1943) - both of which take an ironic view of the links between vice and virtue, cowardice and heroism - should be seen as expressing the dominant ideology of their time, even as they depart from the easy resolutions of the classical Hollywood film. In this wise, both films are accurate distillations of Cold War complexities.

Regarding the Korean War, Susan Carruthers of the University of Wales, Aberystwyth - aided by substantial citations from the research of historian Thomas Doherty - discussed the ultimate Cold War fear, the "brain washing" of American prisoners of war. ("Brain washing" was a term coined in 1950 by journalist/CIA operative Edward Hunter). It arose from the supposition that if science could unlock the secrets of nuclear fission, it could also unlock the human mind. As early as the winter of 1950-51, American television viewers were learning about the plight of Americans captured by the Chinese troops. Universal Newsreel coverage depicted some newly released prisoners who were in obviously pitiful condition. Over these images a commentator proclaimed: "These are American soldiers who dedicated themselves to the United Nation's fight for freedom!"

In what she called the "last Cold War film," John Frankenheimer's The Manchurian Candidate (1962), adapted from Donald Condon's novel, proposed that many of these American prisoners of war had been subjected to mind-altering techniques. There had long been a controversy about the extent to which the surviving 3000 American prisoners of war cooperated with the Chinese Communists. Some returning POWs, suspected of being either willing collaborators or victims of mindaltering techniques, were even sent to a "de-brainwashing" facility in Valley Forge in California before their release back into society. Frankenheimer was familiar with the literature surrounding this sad episode in recent history, and he cited Eugene Kinkead's In Every War But One (1959) as a particularly important influence on the film. "The 'fifties fear of bodily or mental invasion by external forces is, after all, one closely 
associated with the science fiction genre," said Carruthers, "[and] in many respects The Manchurian Candidate seems to owe more to these films than to Hollywood's other 'straight' treatment of the brainwashing of Korean POWs - The Rack (1956) - which was neither a popular nor critical success, and has been little remembered subsequently." Finally, argues Carruthers, the film makes it clear that the real villain was located from within, not without. Any influence exerted upon the POWs, such as it was, was more attributable to their own degeneracy, malleability, and lack of self will than to any external manipulation. Further, any attempts to blame the Chinese Communists for brain washing - a dubious assertion, at best - should be re-directed elsewhere, specifically, to the "mind control" techniques pursued right here at homeby the CIA.

Cold War paranoia was also discussed in two groups of relatively non-political films. The first, examined by Glenn Scott Allen of Towson University and Garrett Rutherford Chaffin of New York University, was a cycle of horror and science fiction movies. In a subject all too familiar to most auditors, Allen made the surprising disclosure that only two films of the time, The Whip Hand (1952) and 1984 (1956), actually contained specific references to communism. Chaffin linked the explosion of cinematic special effects technology, especially in War of the Worlds (1953), to technological advances in nuclear warfare. The second group included the nihilistic, noirish cycle of films by Phil Carlson. "He was the filmmaker par excellence of 1950s paranoia," asserted David Sanjek of Broadcast Music Inc. "There were no stylish affections or preachy political sentiments, just a blunt and sobering confrontation with the bleak urban landscape."

While paying obeisance to Hollywood films like I Was a Communist for the FBI, Garth Jowett of the University of Houston delved deeper into the exotica of American pop culture. His amusing slide-show banter accompanied images of movie posters, comic books (remember Blackhawk?), and bubble-gun cards (in the series, "The Children's Crusade Against Communism"). "We have to go beyond seeking out the obvious political allegories in "50s films," Jowett told this writer in a later interview. "It's like shooting ducks when you start picking on obvious things like Invasion of the Body Snatchers. Not only has it been done to death, but it can be read in many different ways. There are other films that depict American society in more subtle ways. Blackboard Jungle is not subtle, exactly, but it does raise issues that Americans were not keen to have seen by others. In its context of the mid-1950s there was a great controversy in Europe surrounding the film, Rock Around the Clock, which revealed the shift in America from an adult to a youth-oriented culture. And there are other Cold War films which should be studied in terms of their relationship to what we now call cultural imperialism."

"What really concerns me in all of this discussion," concluded Jowett, "is how much of this really affected the public? We can talk all we want to about exposure to a message. But my training as a social scientist tells me we need to be very suspicious about what the so-called "reception" of these messages is. This vague term, "reception theory" should be replaced by "reception studies." We have yet to have a clear idea of how a message is likely to have somehow either influenced or not influenced people, and what is the process by which people are exposed to these images and subsequently 
react to them. Merely saying that there were a lot of movies and comic books with anti-Communist rhetoric doesn't mean that the public was buying in to all this."

\section{THE COLD WAR ON TELEVISION}

The medium of television seized upon the Korean War as an immediate dramatization of the Cold War. In the words of Bjorn Sorenssen of the University of Trondheim-NTNU, Norway, Korean television coverage provided "an ominous example of what would happen if the war turned 'hot." A distinct departure from the traditional newsreel formats of NBC's Fox Movietone News and CBS's Telenews, which viewed the conflict in terms of inflammatory rhetoric and stentorian "voice of God" narration, were the See It Now broadcasts of Edward R. Murrow and Fred W. Friendly. Sorenssen demonstrated that two Korea-related broadcasts, in particular, the premiere program on 18 November 1951 and a special telecast entitled "Christmas in Korea 1952," presented a low-key, "first-person" view of the details of everyday life and the faces of individual soldiers - ideological issues were ignored - with an immediacy hitherto not possible in the new medium. Relating Murrow's style of presentation to the classical rhetorical styles of elocutio (the style of argument) and actio (the manner of delivery), Sorenssen argues that Murrow's great effectiveness as a communicator and the bond he was able to establish with the viewer lay in his rejecting the omniscient "voice-of-God" technique, and adopting the manner of "a fellow human being who offers his character up for judgment as the main guarantee for his argument"; moreover, he "gives an impression of speaking with the soldiers, not to them"; and he is "very obviously a man of the same world as his fellow men, and thus he can lay claim to speaking for them." While Murrow's achievement obviously derived from his radio experience, at the same time he was setting a standard for a new kind of television news coverage. In so doing, as Edward Bliss, Jr., noted in Now the News (1991) Murrow revealed "the nature of the war" better than anyone else at the time.

Was there a connection between the rise of commercial television and American anti-communist attitudes in the Cold War era.? In two presentations about American early 1950s television, David Weinstein, a documentary filmmaker, and Tom Doherty of Brandeis University, seemed to agree that blatantly anti-communist network programs of the 1940s and early 1950s played a significant part in forging a post-war anti-communist consensus in America. Weinstein's supporting evidence was persuasive: (1. Networks aired propagandistic messages in a desire to cater to insistently patriotic sponsors; (2. Programs reflected the fervent anti-communism of key executives, especially NBC's David Sarnoff; (3. Public affairs programs and government films were relatively cheap to produce; and (4. Networks were eager to avoid the imposition of federal regulatory measures. Moreover, all four networks$\mathrm{ABC}, \mathrm{CBS}, \mathrm{NBC}$, and Du Mont - were owned by corporations that were also government contractors in the early 1950s. Frequent customers of the networks were The Atomic Energy Commission and all branches of the military. 
Du Mont especially stood to gain. A small firm in 1941, its business boomed as the nation mobilized for war. After turning over its factories for wartime radar equipment manufacturing, Du Mont positioned itself for post-war expansion by securing government support for the establishment of its experimental station, W3XWT (which later enabled it to operate comercial station WTTG-TV). In turn, as the Cold War intensified, Du Mont aired shows like Visit with the Armed Forces, Guide Right, and The Georgetown University Forum, which gave prominent anticommunist politicians and military officials a platform. At the same time, due to its government and military contracts, Du Mont profited from the military production which the Cold War demanded. Every year until it disbanded network operations in 1955, Du Mont made more money from its government contracts than from its broadcast operation. Thus, says Weinstein, while the connections at Du Mont between national defense and broadcasting were informal, it nonetheless was a company "which depended so heavily on military contracts could not afford to appear soft on Communism in front of the politicians and military officials living in Washington and watching WTTG-TV."

It was no surprise, therefore, that gavel-to-gavel coverage of the Army McCarthy Hearings, from April 27-June 17, 1954, was seen only on the ABC-Du Mont network. Otherwise, as Tom Doherty pointed out, the other networks broadcast only selected segments of the proceedings, while local station owners exercised considerable lattitude in choosing what to air. As familiar as excerpts from the Hearings have become over the years - especially the climactic duel between McCarthy and Joseph Welch-Doherty chose to emphasize a less well-known sub-text that gradually emerged over the weeks and months. The possibility of a homosexual connection between Roy Cohn and serviceman Herbert Schein may not only have been a hidden motive behind the clash between McCarthy's Committee of Special Investigations and the Army, but, as Doherty demonstrated, it might explain some of Cohn's obviously uncomfortable behavior, caught at key moments by the television cameras.

Both presenters admitted afterward that as important as the televising of the Army-McCarthy was in the history of television specifically and the Cold War generally, archival materials are unfortunately either scarce-only a few hours exist in the Library of Congress - or unavailable, locked away at CBS.

\section{THE BLACKLIST--General}

During an interview, Raymond Fielding of Florida State University, admitted that while everybody talks about the Blacklist, little direct evidence-call it a "smoking gun"- has come to light. "I recall many years ago when Howard Suber of UCLA wrote his dissertation on the Hollywood Ten, he kept saying we have no "smoking gun," said Fielding. "We have nothing in writing that can pin the Blacklist on any executive. Well, about 18 years ago I had access to files at RKO Radio Pictures. I came upon a "smoking gun" for Howard Hughes. The only one we have. I have a copy of the documents, in which Mr. Hughes brings his authority to bear upon the Communist threat. It's a memorandum created by his secretary in which he outlines 
how the studio will respond to the Communist threat, to the effect there will be no credits on films of workers who had failed to satisfy HUAC about their status. It dealt with the firing of these individuals and the exclusion of them from employment at the studio. Today, it is of great historical value. It runs for two or three pages. Perhaps I will write about it for the Journal. Things of this sort you can build upon, which would lead to a discussion of Hughes and his place in society and in the film world in particular."

A particularly well-known document from the Blacklist era is Salt of the Earth (1954), Herbert Biberman's docu-drama about striking New Mexico miners and their deplorable working and living conditions. Blacklisted by the Hollywood studios, Biberman gained financing from the miners' union. According to a presentation by James J. Lorence, of the University of Wisconsin, when Congress was alerted to this supposedly "subversive" project, it grew alarmed that it might jeopardize Latin American relations. Subsequently, the American Legion protested it and many theaters and union projectionists who abided by the blacklist refused to screen it It did not go into a general release until 1965.

\section{THE BLACKLIST-Personal Testimonies}

Stephen Peet, former producer of BBC documentaries, and Augusta Perrin, former filmmaker for DEFA-Film Studios and GDR-Television, put a face to the otherwise murky story of blacklisting. In an poignant, moving presentation, Peet recounted how he found himself in a blacklist of sorts in Britain. His brother, John Peet, Chief of Reuters, Berlin, defected in 1950. Stephen showed a newsreel in which John declares: "I don't wish to serve the war mongers any longer. . . . I'm sure there will come a time when all journalists can be decent and peaceful." Four years later Stephen learned that because of the defection, he was now under scrutiny. Two years later, he was unsuccessful in trying to join the BBC. By 1966 he learned with a certainty that he had been blacklisted. He took the matter to his local M.P., and for the next fourteen years he was able to work on the Yesterday's Witness oral history series. He retired in 1980. In 1985 The Observer published an expose of the BBC blacklist, "The Blacklist in Room 105."

Ironically, Stephen was able to use the contact with his brother to make a film in East Germany for the World in Action series. "Life Behind the Wall" was made 35 years ago. It was the first film made in East Germany by a filmmaker from the West. During a visit to a documentary film festival in Leipzig in December of 1962 (just a year after the erection of the Berlin Wall), he got permission from the Minister of Culture to make a film on life in East Germany. With a $16 \mathrm{~mm}$ Bolex camera, he traveled to Weimar, Erfurt, Eisenhuettenstadt, and Dresden to observe the lifestyles of ordinary citizens - a housewife, a dentist, a farmer, a soldier, a foundry worker, and a school girl. The film was produced for Granada Television. Ironically, it was refused entry a year later in the Leipzig Festival. Details linger in the memory, a visit to Buchenwald, soldiers patrolling the border (their mundane activities counterpointed by the menacing strains of Stravinsky's Rite of Spring), a farmer's delighted response to the acquisition of a new tractor, children playing in a schoolyard.

Augusta Perrin brought her film, I'm a Negro, I'm an American, a documentary account of the life of Paul Robeson. It was produced by DEFA 
(Dokumentarfilme/Chronos-Film) in 1989. Robeson's passport had been withdrawn in the 1950s because of his purported communist sympathies. In effect, he was blacklisted, and his concertizing severely curtailed. This was meat for a procommunist tirade against capitalist repression. Repeatedly, the narrative voice insisted that the American "ruling class" was trying to kill him. Pete Seeger's first-person account of the Peekskill debacle seemed to confirm this. Filmmaker Perrin herself had suffered under a kind of blacklist of her own - her name was taken off the Robeson film and it was finished by other hands. Thus, although it was marred by disjointed editing, poor film quality, and sloppy continuity, it remains today a valuable example of a dual kind of censorship — repressive policies by the U.S. government that affected Paul Robeson, and the blacklist exercised by the East Germans against filmmaker Augusta Perrin.

\section{AMERICAN CONTROLS/ SURVEILLANCE OF HOLLYWOOD}

Some surprising revelations (to this observer at least) about FBI surveillance of Hollywood movies during 1942-1958 came from John Noakes, of Franklin and Marshall College, Lancaster PA. As early as the mid-1930s, J. Edgar Hoover expressed misgivings about Hollywood movies, especially those like G-Men (1935) and Publilc Hero Number One (1935), which portrayed FBI agents as detective heroes. Not only did he fear they fueled the ambitions of super-patriotic amateur sleuths, but he may have felt they undermined his attempts to claim personal credit for all FBI activities. But weightier matters soon claimed Hoover's attention. Convinced that remarks made by a communist leader, Gregory Zinoviev, to the effect that the motion picture "can must become a mighty weapon of Communist propaganda for the enlightenment of the widest working masses," Hoover shifted the FBI's view toward the supposed subversive content of movies.

During the first phase of its surveillance, 1942-1945, the Agency confined its overview to the purported communist political affiliations of movie makers. By 1945, this purview had expanded to the compilation of information on images, themes, and plots of suspected movies. Reviews in The Daily Worker were scanned, scripts were examined, and confidential information from informants was gathered. After 1947, with the HUAC hearings in session, the need for FBI undercover operations lessened considerably, and by 1958 the L.A. field office reported that communist infiltration of Hollywood "is practically non-existent at the present time." Subsequently, from 1947 to 1958 , the FBI files on communist acctivity in Hollywood are primarily concerned with reports on movements in Hollywood to support the Hollywood Ten and oppose HUAC.

Citing findings collected in Dan Leab's Communist Activity in the entertainment Industry: FBI Surveillance Files on Hollywood, 1942-1958 (1991), Noakes selected eight films that came under FBI opprobrium for discussion. The Best Years of Our Lives (1946), for example, was discredited because two cast members allegedly had communist ties and because criticism of Russia is associated with "anti- 
semitism, Jim Crowism, and Ku Kluxism." It's a Wonderful Life (1946) was "a rather obvious attempt to discredit bankers" and magnified the problems "of the so-called 'common man' in society." Other films, including Crossfire (1947) and Pride of the Marines (1945) allegedly belittled American institutions and glorified anti-American or pro-Communist values. Social ills like racial injustice, political corruption, and the post-war problems faced by returning soldiers were, as Noakes claims, "recast by the FBI as criticisms of American institutions or advocacy of an alternative economic or political system."

Noakes concluded by noting that the FBI did not pursue criminal prosecutions under the Smith Act in order to prosecute Hollywood filmmakers. "To do so, the FBI would have had to risk exposing the informants and the investigative procedures the FBI employed in Hollywood." In addition, "the FBI ran the risk of looking foolish should the public reject their analysis of what constituted a subversive movie." Instead, the FBI laundered its surveillance information through HUAC. This was a boon to the publicity-hungry HUAC, who, according to Noakes, "had scheduled the hearing and had begun subpoenaing witnesses without any significant information on the presence of Communists in Hollywood."

\section{TRANSITIONAL WORKS}

\section{UPDATING THE HISTORIOGRAPHY}

Peter Rollins of Oklahoma State University chaired the panel, "The Cold War and Communism: Updating the Historiography"-

In the plenary panel, "The Cold War and Communism: Updating the Historiography," chairperson Peter C.Rollins of Oklahoma State University, and three speakers directly refuted what has been called a revisionist view of the Cold War, i.e., that it was American policy, not Soviet aggression, that fomented Cold War hysteria; that the American Communist Party played only a negligible part in the period, and that there was little effective Soviet spy infiltration of the U.S.; that HUAC and the Blacklist were unwarranted victimizations of innocent people; that the Rosenbergs and Alger Hiss were innocent; etc. This anti-anti-Communism-what Lionel Trilling called "that meeching phrase" - has survived the death of Communism. As recently as the publication of George Kennen's At a Century's Ending: Reflections, 1982-1995 (1996), for example, we still find that the man who defined the American policy of "containment" in 1947 is now defending his subsequent conviction that militarizing Europe's territory around a superpower confrontation kept the Soviets from 
withdrawing from their positions; moreover, it corrupted Europe's self-reliance and spawned a military-industrial complex in America itself.

"For several years now, we have labored under the revisionist view that the Soviet Union was forced to produce its massive war machine because of its fear of encirclement," said Rollins in his opening remarks. "According to this interpretation, the Soviet Cold War military buildup and posturing was really induced by the massive military buildup of the United States and its allies." Rollins drily noted this thesis was strongly represented the preceeding evening in the screening of Margolis' Are We Winning, Mommy? However, Rollins pursued, recent findings of books like Richard C. Raack's Stalin's Drive to the West, 1938-1945 [and, it must be noted, John Lewis Gaddis' We Now Know: Rethinking Cold War History (1997), Vladislav Zubok and Constantine Pleshakov's Inside the Kremlin's Cold War (1997) and the ongoing publications in the Bulletin of the Cold War International History Project at the Woodrow Wilson Center in Washington] contain many fascinating insights for those trying to rethink the legitimacy, or illegitimacy, of such a paradigm - in this case, the justification of Allied fears of the Soviets after V-E Day, 1945. Can it be, Rollins suggested, that once our blinders are off, there is indeed a new story to be told concerning the goals, methods, and successes, of Communist infiltration of the motion picture industry? In conclusion, we must move beyond the Cold War paradigm and define new approaches to the Cold War. Otherwise, we hazard the danger of doing mere re-runs of existing work. The Cold War is over. W.H. Auden's "Age of Anxiety" is no longer with us. Let's approach the subject with fresh information and a new historiography. The work of the scholars here have made me aware of the limitations of my own early Cold War studies. Hopefully, we will gain new perspectives on the Cold War."

John E. Haynes is from the Manuscript Division of the Library of Congress. He is the editor of the Newsletter of the Historians of American Communism. This organization has been in existence for 16 years, and is comprised of members from a variety of backgrounds, former members of HUAC, and of both Communist and anti-Communist persuasions. Its main focus is the meaning and significance of the American Communist Party — whether its life and meaning resided in its links to Soviet Russia; or if it grew out of essentially American roots, with only superficial roots to the Soviets. The latter view, espoused in David Caute's The Great Fear: The Anti-Communist Purge Under Truman and Eisenhower (1990), declared flatly that "there is no documentation in the public record of a direct connection between the American Communist Party and espionage during the entire postwar period." As a consequence, America's paranoia about the "Red Menace" was largely a figment of its own paranoid imaginations. It is this latter view that has prevailed for the last twenty years.

Haynes spoke about two important archival finds that may force a review of this position. Since the Soviet Union came apart a little over five years ago, he and other historians and archivists have awaited the opening of long-sealed archives in Moscow and other capitals of the former East bloc, hoping for new light on old questions. In 1992, Haynes and Professor Harvey Klehr of Emory University brought back from Moscow startling documents from the records of the Communist International (better known as Comintern) dealing with the activities of Communism in 
America. In addition, the existence of the records of the American Communist Pary (CPUSA) were located. They had been secretly shipped to Moscow and hidden for many decades. That these records even existed had been only the subject of rumor and speculation. They were all housed in the Russian Center for the Preservation and Study of Documents of Recent History, an archive of 150 million documents, the principal repository of Soviet Communist Party documents, from the Bolshevik Revolution to the death of Stalin in 1953. Haynes went to Moscow in 1993. During this and three subsequent trips, he examined 4300 file folders - thousands of pagesrelating to the years 1919-1944. Volume One of a projected series has been published by Yale University Press, The Secret World of American Communism, co-edited by Harvey Klehr and Friedrich Firsob (1995); Volume Two, The Soviet World of American Communism, is forthcoming in January 1998.

Many of the findings in Volume One contradict accepted revisionist views. The first volume chiefly deals with underground espionage in the 1930s and the enormous amounts of money that were spent to promote that espionage. It was found that a young Armand Hammer had helped to launder Soviet money; that the CPUSA had active ties to Soviet intelligence operations; and that the CPUSA had established secret caucuses in agencies like the Civil Liberties Subcommittee of the Senate Labor and Education Committee and the Office of War Information.

The second volume deals with the Soviet's relation with the American Party. Unfortunately, some of the most significant material is not yet available to the West. The Foreign Intelligence Service of Russia, while releasing some material, has not opened to general research the archives of its Soviet-era predecessors, like the KGB. Nonetheless, concludes Hayes, "It will no longer be possible for any historians interested in the overall history of American Communism to write without using the American Party records, which are in Moscow, and Moscow's own records about the American movement."

The second new source are the Venona Papers, named after a secret U.S. government project to decipher World War II cables between Soviet diplomatic offices in the U.S. and Moscow. For a long time certain Soviet ciphers, the so-called "OneTime Pads," were considered undecipherable. These were codes devised for one-time use only. But during the course of the war, the Soviets grew lazy and began using some of these codes over again. As a result, about 5,000 pages of cables from America to Russia have been decoded. They reveal information about extensive Soviet intelligence operations among some 400 highly-placed Soviet agents in America. Revelations include evidence that many of the Americans who spied for the Soviets were members of the American Communist Party; that the Rosenbergs and Alger Hiss were guilty; that at least one White House aide, Laughlin Currie, cooperated with Soviet intelligence; and that the highest ranking civil servant in the U.S. Treasury, Harry Dexter White, spied for the Soviet Union. In 1995 The National Security Agency declassified these documents, put them on the Internet, and made them available to selected libraries. A book is in preparation for the Yale University Press.

What can one conclude from all these new findings? Arthur Schlesinger's statement in 1949 seems quite prescient, that although the American Communist Party was obviously negligible in itself as a political force, it had much greater influence as a powerful "underground apparatus and through the collaboration of fellow travellers." 
Seemingly, the view that there was no meaningful link between American communism and Soviet communism, or between the American Communist party and Soviet espionage, is, in the light of the new evidence, unsustainable. For example, as Haynes pointed out, the National Standards for United States History, which has been promoted as a guide for history teachers, repeatedly condemns McCarthyism as an unmitigated evil (which, at least in its public impact, was true) and treats the Hiss and Rosenberg episodes with shifty ambivalence (neither denying nor asserting their guilt). Of the active participation of the American Communist Party in Soviet espionage, there is silence. In Haynes' opinion, “these silences about key facts of the postwar era demonstrate an unwillingness to face the truth. ... One cannot deny that American communism was bound heart and soul to Joseph Stalin. Nor can one deny that the American Communist Party as an institution as well as hundreds of American Communists as individuals cooperated with Soviet intelligence services in espionage against the United States."

As a footnote to this, by now it is well known that Federal agents, in turn, heavily infiltrated the CPUSA. According to Ronald Radosh's recent article in the Times Literary Supplement, "American anti-Communists used to joke that, were it not for the FBI, the party would quickly go out of business." There is no mention of that here. The interested reader is referred to John Barron's Operation Solo (1997).

Richard Raack is Professor Emeritus, School of Arts, Letters, and Social Sciences, California State University. In line with the conclusions of John Lewis Gaddis in his recent We Now Know: Rethinking Cold War History, Racck claims that our Cold War fears of the Soviets were justified. New findings place the blame for escalation squarely on Stalin. Indeed, Stalin and Chairmain Mao were the sole authors of the Korean War. The revisionist literature that softened the blame is now being revealed as a lie. You can throw out the Cold War texts and films. Soviet claims of peaceful motives is a lie. The agendas of Lenin and Stalin were quite clearly expansionist. Their own words condemn them. As early as 1919 Lenin is declaring the Soviet plan to dominate other countries. After 1923 Stalin is saying the same things. His 1939 statement is a blatant confirmation of Soviet aggression to conquer the West: "Comrades, it is in the interests of the USSR - the motherland of the working class - that war should break out between the Reich and the capitalist AngloFrench bloc. We must insure the war lasts as long as possible with the purpose of weakening both sides. ... We shall have a broad field of activity for the development of the world revolution."

Daniel Leab, Professor of History at Seton Hall University and General Secretary of the Historians of American Communism. In a rambling discourse he seemed generally in agreement with Rollins and Haynes. He noted that although today we tend to think sympathetically of the Hollywood Ten, we find upon reviewing the subject that they opportunistically exploited what we would now call a "victim" sensibility. Leab even claimed that the blacklisted writers and directors had more success working their trade than is generally acknowledged. In the open forum following his talk, Leab cited the example of Walter Bernstein. Bernstein, of course, was the blacklisted New York writer who was boycotted by Hollywood studios for 
eight years and by the television networks for another three. He never denied he was a Communist. He joined the party in 1946 and remained a member for the next ten years, resigning only after the Red Army's crushing of the counter-revolution in Hungary. Years later he turned his story into a screenplay for Martin Ritt's The Front (1976), and most recently into a memoir, Inside Out (1996). Leab questioned Bernstein's "self-serving" portrait of himself in Inside Out as a hapless victim of the Blacklist. While acknowledging Bernstein's subsequent difficulties, Leab asserted that Bernstein was indeed able to keep working - a fact in stark contrast to what he might have faced in a Soviet regime in reverse circumstances. (Bernstein's script for The Front was discussed several days later in a presentation by Victoria Stiles of SUNY at Cortland.)

\section{PREMIERES AND PREVIEWS}

The conference showcased several American and world premieres in addition to offering tantalizing glimpses of things to come. The afore-mentioned Paul Robeson film by Augusta Perrin had never been seen in the West. Neither had Heiner Carow's seminal East German film, Coming Out (1989). In his screening of excerpts from the Carow film, one of the Ueberlaueferfilme ("transitional films") of the last years of DEFA, Ruediger Steinmetz of the University of Leipzig noted that it was the story of a high school teacher's coming to terms with his homosexuality. "Films like this marked a passage from one political system to another," explained Steinmetz. "Coming Out marked the first time male sex was depicted in the GDR. It was a plea for understanding and tolerance among viewers."

It must be remembered that some of the images shown at the Conference, like the aforementioned television coverage of the Army-McCarthy Hearings, or excerpts from Sesame Street programs (courtesy of Robert W. Morrow of the University of Maryland) - so familiar to American audiences - were actually first-time experiences for many Conference attendees from the former Soviet-bloc countries. Indeed, the uncut kinescope footage from the 1954 Hearings was not only a revelation to those viewers but to the rest of us as well who never see more than the few scant seconds of the famous confrontation between Joseph Welch and Joseph McCarthy. As for the Sesame Street clips, they elicited the most amusing moments of the Conference when, during an after-hours conversation outside the residence halls, Wilhelm van Kampen, Peter Kraemer, and Karston Fledelius debated the political and cultural significance of American pop culture figures like Barney, Daffy Duck, and Kermit the Frog. It was a wild and energetic debate, but discretion forbids further comment.

There were "sneak previews" of two ambitious documentary series soon to be seen on American television. People's Century is a joint production of the BBC and WGBH. The 26-episode program will be aired on PBS in the Spring of 1998. "I doubt if I ever work on anything this big again," said Christine Whittaker, Archive Producer of the Documentaries and History Department of BBC Television. "After all, when 
you think about it, you're talking about the whole of the century and the whole of the world. How can you ever do anything bigger than that? It's already being called the most ambitious series ever made. We made it for a mass audience and not for a group of scholars. We wanted it to be accessible." Of one of the two episodes shown at the Conference, "Boomtime," Whittaker added: "It's an optimistic story of prosperity after the war. People started enjoying themselves again." It was a delightful viewing, a needed leavening of the spirit after some of the heavier presentations of the day. Particularly amusing moments included newsreel footage of the introduction of CocaCola in Europe, television ads for cars (remember Dinah Shore's rousing anthem for Chevrolet?), optimistic views of the housing boom, and some poignant home movies. Just as photography researchers increasingly are ransacking private snapshot collections for candid, unstudied views of domestic history, so too are archivists like Whittaker seeking out home movies. "Almost every episode of People's Century has got home movies in it. In an episode called 'Brave New World,' we found several particularly exciting bits of home movies. One was an interview with Gayle Halvorsen, who was an American pilot in the Berlin Airlift, who figured quite prominently in the newsreels of that time. They called him the 'Chocolate Uncle,' because he used to drop sweets for the children of Berlin. Well, we found Halvorsen, and he happened to have had a $16 \mathrm{~mm}$ color camera with him during the Berlin Airlift. We even managed to trace one of the children he'd dropped sweets to. Another exciting home movie thing was from one of the Americans who had gone to the Moscow Trade Fair in the late 'fifties. He had a $16 \mathrm{~mm}$ movie camera with him, and he got footage of the Kruschev/Nixon 'kitchen debate.' No one had seen this stuff before we used it."

Taylor Downing, Managing Director of Flashback Television, London, brought glimpses of another major documentary series, Cold War. The project was commissioned by Turner Broadcasting. Turner, whose favorite television documentary series is World at War, contacted Jeremy Isaacs to produce a series documenting the Cold War years. Isaacs brought in Downing, and they formed a company to make 24 one-hour episodes. Composer Carl Davis, famous for his long association with series like World at War and the Kevin Brownlow Hollywood series, was called in to write the score. Cold War will air in Europe in the spring of 1998 and will come to America on CNN in the Fall of 1998. Downing reported that Turner has said he's so anxious to have it shown on Russian television that he'll give it away if necessary.

The excerpts Downing screened were Avid digital off-line cuts. Excerpts from the third episode, which dealt with the Truman Doctrine, included newsreel footage of the Christian Democrat victory over the Communists in Italy, aided from the newlyformed CIA. From the ninth episode, entitled "The Wall," were events from the construction of the Berlin Wall in August 1961, from barbed wire to the wall itself. The tank stand-off at Friedrichstrasse. From the eleventh episode, there were startling films of the age of Sputnik, of Soviet missile disasters where a flaming holocaust engulfed crewmen.

Downing noted that the window that opened worldwide permitting researchers access to archives is now closing.

"We have an awesome responsibility to be taken seriously," declared Downing. "But I believe there is now a generation of television historians prepared to maintain 
the highest possible standards." This was a shot across the bow to historians disgruntled with the dramatic license all too often enjoyed by documentary producers.

\section{COLD WAR FROM OTHER POINTS OF VIEW}

Several presentations regarded the Cold War through British, Russian, Dutch, German, and French eyes.

In "Enemies Without and Within," Tony Marczan, of Hopwood Hall College, Lancashire, chronicled the "strenuous attempts" of the Thatcher government of the 1980s to promote an anti-communist posture. Although Marczan didn't note it, it's important to know that this was in decided contrast to earlier attitudes, by the Tories as much as by the Left, critical of the American witch hunts. As Geoffrey Wheatcroft has noted in a recent article in the Times Literary Supplement, the anti-Communist hysteria typified by the McCarthy era and its subsequent blacklisting "was seen as hysterical over-reaction, and as a mistake worse than a crime." Americans were advised that the Communist menace "was best left to wither on the vine rather than nourished by persecution." At any rate, Thatcher's new militancy was in accord with then-current books by General Sir John Hackett and President Richard M. Nixon that claimed the West "had been engaged in a losing battle with the USSR since 1945." Meanwhile, there was no support in Britain for the Soviet-imposed rule over Eastern Europe. Commercial television broadcast dramatizations of John le Carre's Tinker, Tailor,

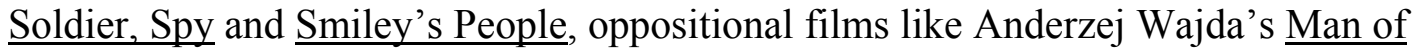
Marble and Man of Iron, and docu-dramas produced by Granada Television were broadcast on the BBC and ITV. Regarding the intense nuclear debate transpiring at this time, non-theatrical films like The Peace Game, produced by the Central Office of Information for the Ministry of Defence in 1982 - a response to Peter Watkin's antinuclear classic, The War Game-was part of a government-led campaign against the teaching of "peace studies." Present in many documentary films intended primarily for internal consumption and education distribution-especially to students in the 16-19 year age range - were claims that power stations were primarily for civil use, disguising the truth of the situation- - "that the primary purpose of nuclear power stations was to provide highly irradiated uranium or uranium oxide fuel rods from which weapons grade plutonium could be extracted."

To be sure, there was considerable dissent. The internal solidarity usually considered necessary to face a deadly external foe was never achieved. Oppositional television, especially drama, provided a counter to "the daily stridency of government rhetoric." Indeed, according to Marczan, "during a decade of ferocious internal antagonisms, the best of British TV drama sustained the soul of the nation." For example, there were numerous anti-nuclear statements in the 1980s, particularly in the

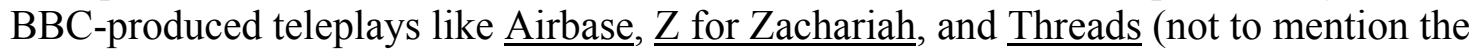
importation of the American television drama, The Day After), the Channel-Four produced When the Wind Blows, an animated tale of the effects of nuclear war on a middle-aged couple, and Edge of Darkness, an expose of the use of a privatized nuclear 
processing facility toward militaristic ends. This latter film is, in Marczan's opinion, "the strongest statement of dissent during the decade."

Graham Roberts of the University of Leeds discussed British newspaper coverage of Gorbachev in the years 1985-1991. The press was mixed in their assessment of him, regarding him, on the one hand, as an absolutist at the head of the Soviet Machine, and, on the other, as a Western-style politician. In a wry footnote, Roberts showed several cartoon caricatures of Gorbachev. In their clumsy attempt to strike a likeness, contended Roberts, we see the overall confusion about him.

The interpretation of the Cold War in France and Quebec was the subject of a paper by Susanne Langlois of McGill University, Montreal. Unlike the situation in America and Britain, there was no wave of anti-communist films to come out of France at this time. The French Communist Party was strongly entrenched by the end of the war. Part of its agenda was to counter Allied newsreel propaganda. This became increasingly difficult in the early 1950s with the increased interest by French critics and filmmakers in American cinema. In Quebec, the situation was somewhat different. The Party's post-war propaganda effort was stifled by Quebec film censorship, which strictly forbade communist-related films. The work of The National Film Board of Canada, then suspected of communist associations, was also banned. Langlois pointed out, however, that despite censorial restrictions, the communist party was in fact instrumental in stimulating several social reforms.

Sergei Drobashenko of Moscow State University documented instances of Soviet Cold War propaganda in film and television in the 1950s and 1960s. "The capitalist world was no longer represented just as an anti-humane system," reported Drobashenko, but as a "treacherous and agressive" element in Western civilization, pursuing an agenda of "deceit and oppression of nations." Apart from the work of commercial filmmakers like A. Zarkhi (In the Name of Life, 1947) and F. Ermler (Great Force, 1950), who depicted the "decay" and "perfidy" of capitalism, and agitprop newsreels like News of the Day ("Against the Crimes of American Aggressors in Korea," "Hands off Lebanon, Iraq, Jordan," "Hands off China," etc.), there were scattered instances of filmmakers who achieved a greater subtlety, even political ambivalence. For example, excerpts from two of Michael Romme's features were screened. Murder in Dante Street (1956) and Secret Mission (1950) were set, respectively, during the French Resistance in 1940 and during the closing months of World War II. In the first, a mother, who is sympathetic to the communists, is betrayed by her Nazi collaborator son. In the second, plans by a secret American delegation to negotiate the unilateral surrender of Germany (which would permit a united force to be subsequently directed against the Soviets) is foiled by Soviet intelligence officers in Berlin. What is noteworthy about the latter film, comments Drobashenko, is that the "conspiracy" is presented as indisputable fact rather than mere rumor and innuendo. Drobashenko concluded with a personal footnote about Romme. He grew bitter about his participation in such propaganda films and confessed to a creative crisis. "Thus, we see one more confirmation of the well-known truth that once an artist, however wellmeaning, starts telling lies, his wisdom and talent fail him."

According to David J. Barnouw, of the Netherlands State Institute for War Documentation, the Anne Frank story become a political football in the early 1960s. The GDR-produced Ein Tagebuch fuer Anne Frank was banned by Dutch censors. 
The 20-minute documentary, directed by Joachim Hellwig, depicted the anti-Jewish raids on the Amsterdam Waterlooplein, the deportation train from the transit camp Westerbork to Auschwitz, and footage from Auschwitz and Bergen-Belsen.

Problematic to the censors was the portrayal of the Federal Republic as a "direct, guilty descendant of the Hitler regime." Particularly troublesome were revelations that those involved in Anne Frank's incarceration and fate were still living comfortably in the Federal Republic. Although the prize-winning film garnered attention elsewhere, "its impact in the Netherlands was nil."

In the only major Conference presentation regarding radio in the Cold War, Michael Nelson, former general manager of Reuters, demonstrated that Western radio, particularly the BBC, Radio Free Europe, Radio Liberty, and the Voice of America, were effective forces in the fight against communism and the fall of the Iron Curtain. The attempts by the Soviets to thwart the broadcasts by jamming of transmissions and stopping the mass production of short-wave radio receivers were ineffective, claimed Nelson. "Pop music, talk shows, news, and information about consumer goods all relayed a message of the good life, subtly undermining the values of the communist regimes."

Wilhelm van Kampen, Director of the Film Section, Landesbildstelle, Berlin, our host last year at the Berlin Conference and a past president of IAMHist, told the story of the Cold War and the Fall of the Berlin Wall through German eyes. The always amiable Wilhelm was a ubiquitous presence throughout the Conference; many of the films and telecasts he brought had never been seen in America. He provided an ongoing English translation to the Baumeister des Sozialismus ("Master Builder of Socialism: Walter Ulbricht"). In another presentation, "The Fall of the Wall," he analyzed GDR television coverage of the huge East Berlin rallies in November 1989, when some of the regime's most prominent intellectuals called for fundamental reform. Since the construction of the Berlin Wall in 1961, citizens of the GDR had been subjected to an intrusive and authoritarian police state. As late as 1988 hopes for the Wall's collapse and a German reunification were still dim. Everyone, including Chancellor Helmut Kohl, presumed that German unification was, at best, years in the future. The rapidity of ensuing events could not have been predicted: In May 1989 East German refugees were crossing to the west via the newly opened Hungarian border with Austria, or seeking refuge in the West German embassies in Hungary, Poland, and Czechoslovakia. Once this door was opened, East Germany lost the capacity to save itself with either repression or stringent economic reforms (remedies thast might have increased even more the westward flight of its citizens). By November 9, when the East German authorities hastily announced the opening of its own frontiers and the Wall was overrun, an estimated 32,000 East Germans had already escaped. Van Kampen's excerpts from the "live" telecasts of political speeches and song, of the frenzied crowds impatient to cross through Checkpoint Charlie were riveting. Who can forget the moment when an excited woman kisses an East German border guard when she learns she may pass through to the Eastern sector to see her family? Indeed, one senses that at this moment the death sentence of the GDR was signed. 


\section{FIELD TRIPS}

Breaks in the long and intensive sessions were welcome. In addition to the latenight sessions at Fratelli's restaurant, there were three memorable excursions. A twilight picnic on the grounds of the Salisbury campus consisted of bratwurst, hamburgers, and fried chicken, garnished by the usual selection of drinks and desserts. Mid-summer temperatures were exceptionally mild, and the white picnic tables scattered under the greening trees made for a most agreeable setting. Later, busses took us the NASA Museum, where members of the German contingent drily noted the absence in the displays of German scientists and German technology. A walking tour of the Chinkoteaque Wildlife Preserve, followed by a few hours at the ocean front, afforded ample opportunities for hiking boots, bird-watching, and sun-bathing. One prominent member of IAMHist, whose name discretion bids me withhold (although his initials are "C" and "F"), was observed disporting himself shamelessly about in the surf. The local press, astonished at the sight, closed in for a closer look.

The last day of the Conference, 31 July 1997, was spent in Washington, D.C. at the National Archives (College Park) and the Library of Congress. At the Archives auditorium, after greetings by our hosts, David Kepley, Chief of the Archives' Motion Picture, Sound, and Video Branch, and William Murphy, Specialist in Audiovisual Archives, Nontextual Archives Division, we settled in to a program of USIA documentary concerning the Cold War. The Wall (1963), produced to commemorate the first anniversary of the building of the Berlin Wall, was a poetic evocation of the hardships and dangers the repressive climate held for those separated from their families and for those, like the unfortunate Peter Fechta, who tried to escape. The Death of Imre Nagy (1959) profiled the career of the man who led Hungary through a period of relative moderation in the mid-1950s. After the Budapest riots were crushed by the Soviets, Nagy was seized, secretly tried, and executed in 1958. Czechoslovakia (1969), which won an Oscar in 1970 for Best Documentary Short Subject, encapsulated the span of Czech history from 1918-1968 in a scant fifteen minutes.

Afterward, Kepley, Murphy, and a third guide, Les Waffin, conducted tours of the facility. Erected in 1993, Archives II, as it is called, is the largest archives building in the world. Together with the historic National Archives Building in Washington, D.C., the new facility assists the National Archives in the Washington area in acquiring, preserving, and making available to the public records of historical and cultural value. Its staff of 600 personnel, assisted by 200 contract support workers, administer the Research Room operations, state-of-the art labs, lecture rooms, storage vaults, a day-care center, presently stores two million square feet of archival material. Archives II has all special media records, including motion pictures, still pictures, sound recordings, maps, architectural drawings, aerial photography, and electronic data relating to such matters as the military, foreign relations, commerce, labor, transportation, fiscal policy, energy, and social issues. The audiovisual collection alone consists of more than 150,000 reels of film, 160,000 sound recordings, and a rapidly growing collection of more than 20,000 videotapes. In addition to USIA films, and Universal newsreels are Voice of America broadcasts, short-wave broadcasts from foreign countries, Civil Defense agency films, interviews for CBS/Longine Wittnauer, etc. 
The ease of access, not to mention the general permission granted to those who wish to copy or dub audiovisual materials, caused more than one European archivist's jaw to drop. I was particularly impressed when, at my request, David Kepley located a print of Walt Disney's notorious World War II feature, Victory Through Air Power (1943) for screening. It's there, waiting for me. Next time I'm in Washington. . .

An hour later we were ensconced in the Mary Pickford Theater in the Library of Congress, Motion Picture Section. Our hosts, Cooper G. Graham, Acquisitions Specialist, and Patrick Laughney, Curator of the Pickford Theater, screened excerpts from several classic Hollywood "anti-Red" films. Even though many of us had seen Big Jim McLain, viz., Ron Briley's afore-mentioned presentation on the picture, it was a revelation to see Big John sweeping up Commie trash in a crisp, beautiful $35 \mathrm{~mm}$ print. Several films long regarded as curiosa of the Cold War period, notably I was a Communist for the FBI (1951) and My Son John (1952), as well as underrated classics like Elia Kazan's Man on a Tightrope (1953) were well served in arresting, thoughtprovoking excerpts.

\section{INTIMATE HISTORY}

Away from the Conference rooms, a different, quieter and more intimate kind of historical chronicle unfolded. During breaks, meals, and late-night relaxation at Fratelli's, a nearby Italian restaurant, attendees from far-flung points of the compass exchanged their own personal histories. Peter Kraemer of Keele University, Staffordshire, and Ruediger Steinmetz, of Leipzig University, discovered a commonality in their boyhood experiences in Germany. The Cold War years of the ' 60 s held for them little political or dramatic connotations, just the day-to-day business of growing up. Kraemer's youth was spent in Steinbach, north of Frankfurt, near Giessen. While his mother, a single parent, ran the local supermarket, he and his schoolmates led normal lives, except they were always dimly aware that Soviet tanks could come across the border at any moment. Meanwhile, the American military presence at the supply base in Giessen was also vaguely menacing. He remembers the rumbling sounds of truck convoys passing through on maneuvers, although some of the G.I.'s threw them chocolates from the backs of trucks. The African American soldiers, particularly, had a vaguely exotic aspect for children who'd never seen blacks.

Steinmetz grew up in Goettingen, 140 miles south of Hamburg, about ten miles from the eastern border. His father was a teacher, his mother a housewife. He grew up listening to radio broadcasts from GDR radio and television. Sirens sounded through the town on a monthly basis. A stream of Fluchtlinger, refugees, from Prussia constantly passed through the area. Although he recalls the day his father took him to the border for a first-hand glimpse, he didn't actually see any Russian troops until he went to Berlin as a soldier. 
Christine Whittaker, Archive Producer, BBC Documentaries and History Department. I started working on People's Century in 1992. Peter Pagnamente, the executive producer, had already done about a year's development work with historical advisers and researchers. I came on board along with a production manager to try and get the thing going. We were co-producing with WGBH. My job, really, was to coordinate, oversee, and produce, all the archive research. We made 18 of the 26 programs (WGBH made eight). Each is 53 minutes long. There are at least 30 minutes of archive in each program. We're talking about a lot of footage.

I doubt if I ever work on anything this big again. After all, when you think about it, you're talking about the whole of the century and the whole of the world. How can you ever do anything bigger than that? In that sense, it's been called the most ambitious series ever made. We made it for a mass audience and not for a group of scholars. We wanted it to be accessible. "Boomtime," particularly, has a "happy" message to it. It's an optimistic story of prosperity after the war. People started enjoying themselves again. Of course, when the oil shock came, things started going wrong. It was a particularly fun program.

(I noticed the use of home movies.)

Almost every episode has got home movies in it. What has happened is, that archive researchers are talking to each other a lot more. I started doing archive research 25 years ago, and I always worked on big series. In those days, if you did 
international research, you might go to the National Archives or the Library of Congress in Washington, D.C. We feel we are in heaven when we come there, because of all this public domain material. We don't have anything like the Freedom of Information Act, you see. Or you might go to Fox Movietone in New York. And if you were really adventurous, you might go to the Bundesarchive in Germany. But now, every researcher is expected to pull in footage from throughout the world. And it's much easier to do that.

As far as home movies are concerned, you simply advertise. With a lot of home movies, you find the people and they have film. In "Brave New World" we had two exciting bits of home movies in that. There was an interview with Gayle Halvorsen, who was an American pilot in the Berlin Airlift. He figured quite prominently in the newsreels of that time. They called him the "Chocolate Uncle," because he used to drop sweets for the children of Berlin. We found him, and he happened to have had a $16 \mathrm{~mm}$ color camera, and he had done his own filming of the Berlin Airlift. And we managed to trace one of the children he'd dropped sweets to. The other exciting home movie thing was the Moscow Trade Fair in the late 'fifties. There was a famous moment when Kruschev and Nixon had the Kitchen Debate. We interviewed one of the Americans at the Fair, and he had a $16 \mathrm{~mm}$ home movie camera. So we got extra footage of Kruschev and Nixon that no one had ever seen before.

The most exciting home movies I ever found was for a piece about Nancy Astor, an American, the first woman M.P. to sit in the House of Commons. She was married to Waldorf Astor. They lived in a stately home called Clifton, in Britain, a meeting place for literary and political luminaries. They used to have these huge house parties. I placed an advert in the Daily Telegraph asking if anyone had any footage of Nancy Astor. Normally, you get letters, and when you follow them up, it turns out somebody has a copy of a Pathe newsreel, or something. But this guy rung up and said he used to be the electrician at Clifton. And when Clifton was sold-it's now a National Trust — he bid for a film projector he knew was there. He also said that with the projector were two cardboard boxes of film. He asked me if I wanted to have a look. Naturally, I said yes, please. I went down and it was the whole home movie collection of the Astor family. Some of the Astor children, now grown, came down to see it with us. There were shots from as far back as the 1920s. There were views of Macmillan, George Bernard Shaw. It was absolutely incredible.

(Is there a moment of discovery in an archive that you particularly remember?)

It sounds ridiculous, but what you have are high spots of things you particularly love. On this series, things in the program I adore are some wonderful color footage of France in 1912. A Gaumont process, a three-lens color system, almost a precursor of Technicolor. The quality was unbelievable, wonderful footage of people at the beach. That was used in our first program. There was also some early film that didn't end up in the program. I think it was from 1903, a static camera in Paris on one of the boulevards, was positioned outside a public convenience. It was just an uncut film of men going in and out.

(I assume that the more unposed and uncalculated the film is, the more value it has for you.) 
Well it does to me, it interests me. However, in a series like People's Century, each kind of film has its own purpose. Film that is edited and which has commentary, or a newsreel, has a value of its own, too. It's quite difficult to use such footage, though, because it's very different from professionally-shot material. It's got its own pacing, which means you have to use it complete and not intercut it with other material. It doesn't work. Now, of course, every other person has a video camera.

(Are there materials that are particularly hard to locate, for whatever reason?)

Well, I hate to say it — it's terrible, it's awful—but the thing people look for the most is Holocaust material. We did a program for People's Century called "Master Race," and it won the International Emmy; and we had new material in there. In fact, I've been seeing some material recently from a researcher who spent two years touring the world. He's found some extraordinary material. It's awful, it's terrible. Why should we want to see any more?

(Talk about your background and what has best suited you for this job?)

You know, I really don't know. I was a linguist, I did languages at university, the University of Leeds (where Phil Taylor teaches). But I wasn't an historian. I'm not even a particularly visual person. I left university with a degree in French and German. I wanted to be a translator but couldn't find a job. I joined the BBC as a production assistant working in the Overseas Broadcasting section to French Canada. And I then moved to television and became a researcher within the next year and a half. I started doing some film research and I found I was good at it. I left to have my first child. When I came back in 1981 to work on a series called All Our Working Lives, which was a big history of British industrial life, things went from there. I may be the longest serving and most experienced film researcher in Britain, actually. For some reason, I've got a very, very good visual memory. I don't know why, I just do. I've also got a logical mind, I can make connections among all kinds of film sources, and I can fit things together from this place and that place. It's the sort of thing you discover on the job. I'm not an historian. The history I know I've learned on the job.

(Is there a coterie of film researchers, some sort of organization?)

There's now a group called FOCAL, which is a relatively recent organization. It has a quarterly journal. It has archivists as members, too. There's an American Archivists Association. But in fact, it's a small world. The people all know each other. I've know Jerry for years. I've just co-written with Prudence Arndt, who was the Chief Film Reseacher on the Chief Film Reseacher on the ABC Century Series, an article about a big catalogue put together in 1987 by Rick Prelinger which really changed our lives. He was a film collector who'd been collecting industrial films for many, many years. His book was called The Guide to North American Film and Video Sources. There's been an update since then; and they're about to do a 1997 volume.

(How has the advent of video tape affected your research?)

It has created problems. The best and easiest time to research is the golden age of the newsreels from the late twenties to the mid-sixties. There were four newsreels producing several editions per week, in which the major news events appeared. Then 
came a sort of dead period in the '70s. Now, there is so much material, it makes it more difficult to focus. The worst time is in the fifties, live television, before videotape was invented. The quality of telerecordings, or kinescopes, is very, very poor. Newsfilm used in the 1970 s is pretty awful, too. The color is appalling and the color is boring. It was shot on reversal stock, and it's faded very badly. And because there's no negative, there's not much you can do with it. As for two-inch videotape, what can I tell you? It's a nightmare. It's awful. You can't play it back at speed. The BBC Library has been doing an extensive preservation program and it's transferred two-inch tapes onto a digital format. There are still all the one-inch tapes. I've worked a lot with video tape. For People's Century we've done rough-cuts off-lined on Betacam SP. We actually cut on Beta, which we then put on Avid. Then we fine-cut on Avid. We did that because the Avid machines then didn't have a long enough memory for the amount of material we had to deal with. Now, you'd go straight on to Avid.

[Article about Christine in The Daily Telgraph. Offers to send it to me.]

Taylor Downing. Television producer of factual programs in Britain. 18 July.

The creation of Channel Four in 1982. Committed to taking programs not from the $\mathrm{BCl}$ or $\mathrm{BBC}$ (the largest production outfut in the U.K.), or the companies making up the ITV Network (Thames, Granada, Yorkshire, London Weekend, Scottish Television, HTV, etc.). These have traditionally been the basis from which programs have been. When Channel Four established, it said it sought alternative programming from independent companies. That led to a renaissance of small, independent production companies. Downing had spent most of his career in the ITV companies like Thames, working with Brownlow, David Gill, Jeremy Isaacs. He left the ITV world in 1982 to form Flashback Television. Got a commission to make a 20-part history series called Flashback. Other like companies followed suit. In 1990 the Broadcasting Act formalized the system whereby 25 percent of all broadcast programs had to be made by independent companies. The BBC now required by law to take 25 percent of its output from independent producers. Likewise, ITV. Channel Four takes almost 100 percent of its programming from independent producers. Now there are about 100 independent companies. Once they would have made mostly documentaries; but now they are making programs in every programming genre.

The story of Flashback is representative. Its core activity is the making of history programs. Also produces drama documentaries, arts documentaries, lifestyle programs, etc. One of the few companies in continuous existence since 1982. Has produced nearly 400 separate documentary programs. "To navigate the stormy waters of production over that period of time, one needs to have a reasonable diversification of programming and producers." Employs between 20-30 people, many freelancers on a particular project. There are other independent companies larger.

Cold War commissioned by Turner Broadcasting, who specifically wanted Jeremy Isaacs to make the series. Turner was in Leningrad when he hatched the idea to 
do it. His favorite television had been World at War. Jeremy worked initially at Flashback and then decided to form his own company to be the vehicle to make the programs. 24 one-hour programs. With Downing, Isaacs originally envisioned twenty episodes. Eventually expanded to 24. A chronological order was decided upon. Carl Davis commissioned to compose the music. Each episode would be self-contained. Been working on it since 1995 and will deliver it in the spring of 1998, and it will be first transmitted in America on CNN in the Fall of '98. On the BBC2 in Britain. Turner has said he wants it shown on Russian television, even if he has to give away the program.

Conference enjoyed a World Premiere, as it were. Downing screened Avid digital off-line cuts. Excerpts were from the third episode, which dealt with the Truman Doctrine and the subsequent debate. The Christian Democrat victory over the Communists in Italy. Aid from the newly-formed CIA, which had been a result of the National Security Act. From the ninth episode, entitled "The Wall," were events from the construction of the Berlin Wall in August 1961, from barbed wire to the wall itself. The tank stand-off at Friedrichstrasse. From the eleventh episode, there were startling films of the age of Sputnik, of Soviet missile disasters where a flaming holocaust engulfed crewmen.

Downing noted that the window that opened worldwide permitting researchers access to archives is now closing.

"We have an awesome responsibility to be taken seriously," declared Downing. "But I believe there is now a generation of television historians prepared to maintain the highest possible standards." This was a shot across the bow to historians disgruntled with the dramatic license all too often enjoyed by documentary producers. 
Raymond Fielding. 27 July.

I'm Dean of the School of Motion Picture, Television, and Recording Arts at Florida State University. A longtime member of IAMHist, almost since the beginning when he hosted the Journal in Houston, where he was Director of the School of Communication.

(Could a Conference like this have been done very satisfyingly before the Wall fell?) Well, walls keep going up and coming down. There's always a war of some sort. It's the role of the communication theorist and historian to analyze the way in which wars are covered while they are transpiring and then analyze and interpret them after the fact, when you have to put the pieces together and make sense of them.

(Do we have hindsight now on the Cold War?) When I was at Houston, we used to host and supervise the Conference on Freedom of Mass Communication, held at Valley Forge each year. The last one we put on was just before the Wall fell down. I recall at that time that just about every speaker said we had put ourselves out of business. The irony was that we might not have another meeting like this. The USIA representative said that, unbelievably, the Soviets had allowed them to open a bureau in Moscow. Well, that was a sign of things to come. What a splendid opportunity for the academic scholar to come together with practitioners at such a time.

The scholar plays a lot of roles in society. And he had better be prepared to do a lot of broken-field running. Some of us who come to these conferences are also educators, and we must attend to training a new generation of citizens and students. We have an especially important obligation to bring back some insights to them. My counterpart at UCLA, Gil Cates - both he and I are active in the Motion Picture Academy - was quoted as saying that 70 percent of the new directors in the entertainment industry was trained in a film school. This is a sobering thought, wondering who we're turning out after more than seventy years of communications education. We've been in business long enough, collectively, that we can ask ourselves whether out mentors and whether we in turn have done a good job in preparing the historical practitioner. This conference for me is not merely a scholar's delight but an educators' obligation.

(Any questions on your mind as you come here?) 
As a matter of fact, I was going to prepare a paper myself. A perfect opportunity for it. One of the issues one deals with is the growing paranoia of the postWar years. In the communication industry there was great distress with the Blacklist and so forth. That was very unpleasant and very scary and worth restudying. What did Plato say - man will be dead before he achieves peace. In any event, we all know there was a Blacklist that affected many people. I recall many years ago when Howard Suber of UCLA wrote his dissertation on the Hollywood Ten, he kept saying we have no "smoking gun." We have nothing in writing that can pin the Blacklist on any executive. Well, about 18 years ago I had access to files at RKO Radio Pictures. I came upon a "smoking gun" for Howard Hughes. The only one we have. I have a copy of the documents, in which Mr. Hughes brings his authority to bear upon the Communist threat. It's a memorandum created by his secretary in which he outlines how the studio will respond to the Communist threat, to the effect there will be no credits on films of workers who had failed to satisfy HUAC about their status. It dealt with the firing of these individuals and the exclusion of them from employment at the studio. Today, it is of great historical value. It runs for two or three pages. Perhaps I will write about it for the Journal. Things of this sort you can build upon, which would lead to a discussion of Hughes and his place in society and in the film world in particular.

(We most associate with you the newsreel. Is that topic a part of this conference?

Oh, yeah. There are several papers on the subjects of the newsreel archive, which is the foundation for any research on on compilage films. I have written in some length about the need for credibility of compilage films. I have made many films like this myself-I'll work as a filmmaker the first half of the week; then as a scholar in the second, at which point I'll be appalled at what I did!

(Are there still materials about the Cold War coming to light?)

Years ago at a conference in Rochester the late Hal Potter, who had been head of Fox Movietone Newsreels for many years, said they had just discovered a wonderful collection of footage they didn't know they had on Richard Nixon. Now the older collections which I've worked with-Pathe, Paramount, Universal—when I was running a consulting firm in Houston are now fairly well known. An East German collection of Fox Movietones has just been reclaimed. Steve Davidson in Miama at the Wolfson Foundation has had access to independent television station archives. I brought one of these to the Library of Congress several years ago when I was living in Philadelphia. The process took about three years. In time it will be indexed and catalogued. A splendid collection, about three million feet - every format, beginning with film, both color and black-and-white, single system, double-system, two-inch quad, one-inch and all the rest. All from 1949 onward. Covering not only the city of Philadelphia, but also regional, national, and international news. What is happening, as Steve is discovering, is that there are materials we don't know about.

Some archives are now collecting home movies. Which have another purpose, a kind of anthropological study of social moreys. They are very revealing. Often times, amateur footage is of substantial historical value as well.

(Am I right to be alarmed that video tape has documented a whole generation?) 
Yes, video tape is doomed and so are the machines that run it. We're in terrible danger of losing our own generation, i.e., the last thirty-five years or so. Recently, the Library of Congress held a panel of testimonies in Los Angeles from television executives and engineering heads, as well as from librarians and archivists from public and private sectors. The picture is very grim, because, in part, the machines are wearing out. There aren't very many two-inch quad machines any more. When they go, that's the end of it. You can't rebuild them, in most cases. When they go, that's the end of the material. And of course, video tape is a terrible medium; it has no archival integrity. The Library of Congress hearings are just coming out now, and it is hoped they might generate Congressional support for funding for the non-profit archives, which need financial help the most. Digital transfer is about the only process that will help now, but that goes on to tape, too. Plus, the transfer is only as good as the original tape. The problem is the staggering amount of material. I played a role in the recent sale of the Grinberg Library in New York and Los Angeles, which, until fairly recently was also the archive for $\mathrm{ABC}$ Television News. The amount of material that comes in each month boggles the mind. Only about ten percent of it is indexed; the rest goes out to a warehouse in Long Island somewhere.

I just finished a two-year commission, a joint-production of the $\mathrm{BBC}$ and the $\mathrm{CBC}$, a six-part, six-hour series on the history of television news. The first two hours, which was my part (based on my two books), reveals that the visual materials from early years are superior in quality to the video materials from more recent decades. Now so much is on tape.

One of the proposals made by the Librarian of Congress was to standardize just one video format for the next fifty years. At least the machinery would continue to be manufactured during that time. The executive was very sympathetic, but he said it wouldn't work. He said it is the nature of engineers to perpetually improve and change the technology. Nothing would stop that. He couldn't see a cessation of new product for archival purposes.

We have some public support for the salvation of commercial feature films. But the dilemma of video goes largely unnoted. The sheer amount of material is too overwhelming, I suppose.

In November I'll go to the AMIA (Association of Moving Image Archivists). They are 90 percent concerned with the access, use, and preservation of the artifact. That will be in Bethesda. That's the place to go for new information. Another organization, the International Federation of Film and Television Archives, sometimes meets jointly with AMIA. The technology needed to preserve video and other materials is in place, for the most part, the problem is the cost.

Not many young people consider preservation as a viable career goal. Some do as they get into graduate studies. We have just acquired an archivist for a study collection of a million feet of $35 \mathrm{~mm}$ feature films. But filmmakers and consumers are not very concerned. It's our fault, to an extent. We've spent a hundred years of motion pictures and fifty years of television in training the public to look at these media as consumables. Now what will undoubtedly come out of the laboratories in time will be new storage systems which will allow for reliable safety and which can handle the sheer quantity of materials. One manufacturer, I'm told, now has a server, a giant hard disc about the size of a refrigerator, which can hold a hundred thousand titles. This 
will be a real breakthrough for instantaneous access and storage of television programming. It's also a fabulous new approach to archiving. The speed at which transfers are being achieved is increasing.

We talk a lot about how media historians have to be flexible, wary of received opinion, open to new information and new source materials, prepared to review their conclusions and so forth. Well, archivists need to be flexible, too. It places another emphasis on the intellectual and scholastic foundations of scholarship itself and archival procedures, which if they are well grounded and well studied, will serve the archivist and the historian. Historians have always had to be quick on their feet. And so now must the archivist.

Garth Jowett, University of Houston Nicholas Cull, University of Birmingham

(What are some Cold War/media issues that need to be addressed?)

(Jowett) To a large extent, it's been done to death by academics in recent years who've reassessed the Cold War and how it's been portrayed. On the other hand, the general public still sees the 1950s as a happy, complacent atmosphere. And there are current politicians who keep referring to the ' 50 s as a wonderful time that we've lost and have to strive for and regain. In the last ten years, there's been an attempt by academics to rectify that image, to explain to Americans that we didn't really have such a complacent time in the 1950s after all. The "Leave It to Beaver" image is constantly raised. That image has become so ingrained in America, that the Cleaver family has come to represent some sort of reality. Whereas, there was a greater percentage of people on welfare, a terrible situation for women in terms of employment and divorce, a rampant racism, etc. In other words, although academics are constantly revising the " $50 \mathrm{~s}$, the general public has not yet bought in to that concept.

(Cull) I think one of the things we have to look at in a conference like is to look beyond the sort of analysis that has happened so far, like the analysis of motion pictures in the 1950s. We're up to our ears with readings of Invasion of the Body Snatchers and other paranoia films. I think what needs to be done is to understand that the media was an active player in the Cold War; to study the strategic use of radio, of Voice of America and Radio Free Europe; and also the use of propaganda films to affirm American foreign policy. That hasn't been done properly. We wouldn't consider thinking about film in the 1930s without also considering the documentary films used to promote the New Deal. But we approach the Cold War without serious study of film propaganda as an element in American strategy overseas.

(Jowett) Americans don't like to believe that the country propagandizes. It you examine propaganda in any detail in this country, the notion that the government is actively engaged in the active manipulations of people's cognitions is something that is simply laughable to most people. When we do have revelations, like the attempt to bomb Colonel Kadaffi, we have a brief flurry of excitement. We say that we didn't 
realize our country did that; and then people back off. What happens in the $1950 \mathrm{~s}$ is that the government and Hollywood was actively propagandizing. Either we know that, or we don't seem to care very much.

(Accepted opinion is that Hollywood films didn't really have Communist propaganda in them.)

(Jowett) I think that a lot of filmmakers in the 1945-early ' 50 s period were responding to World War II and to the perceived power of the film in World War II to create some kind of shift in public attitudes. In other words, they were actively propagandizing, and if you read some of the literature at the time by the filmmakers, what they were saying was they used movies for good during the War; and now let's try to continue that impetus and use movies for good after the War. Pictures like Gentleman's Agreement and Crossfire were a continuation of the use of the power of the movies, and not an attempt to create an ideological shift. But the sensitivity in America on the part of politicians was that any criticism of society was considered to be Communist. A movie like The Grapes of Wrath was not allowed to be shown in Europe after the War, because it was perceived to be anti-American and proCommunist.

(Cull) There's a great story connected with The Grapes of Wrath. Stalin wanted to show it in the Soviet Union as an example of how bad capitalism was. But audiences responded, marveling how many trucks those peasants had! Great!

(Jowett) Yes, the Russians were amazed that people as poor as the Joads could own a truck! And so Stalin's plan backfired. Now, there's an article that deserves to be done, to examine the list of films that were not to be shown in Europe after the Liberation. Apocryphal as it may be, the story is the Europeans asked for two things from the American occupying forces. The first was food; the second was movies. I don't know exactly how true that is. But certainly the Americans had to draw up a list of what movies could and could not be shown. The OWI made the decisions, especially regarding problem films, like those involving anti-semitism or race relations, etc. When you jump forward to the mid-1950s, you have that famous incident where Clare Booth Luce as Ambassador to Italy, had Blackboard Jungle withdrawn from the Venice Film Festival, where it had won the prize. It was a great controversy, because she didn't want it shown overseas as an example of what American juvenile delinquency was like.

(Cull) The connection between USIA and the Venice Film Festival is sustained throughout the Cold War period. The director of USIA would go to Venice with American films and preside over their screening to European critics; and they'd decide which ones best represented the United States.

(Jowett) We have to go beyond seeking out the obvious political allegories in '50s films. It's like shooting ducks when you start picking on things like Invasion of the Body Snatchers. Not only has it been done to death, but it can be read in many different ways. There are other films that depict American society in more subtle ways. Blackboard Jungle is not subtle, exactly, but it does raise issues that Americans were not keen to have seen by others. In its context of the mid-1950s I was just told that there's great controversy in Europe surrounding the film, Rock Around the Clock That film is such an icon of the shift in American culture from an adult to a youthoriented culture. Apparently that film caused quite a stir in Europe as well. There are 
other Cold War films which should be studies that relate to what we now call cultural imperialism.

(Cull) Maybe it's time to move beyond the term, "Cold War," which in itself is a construction of American culture. Rather, talk about the projection of American power, culturally and militarily, during this period. That provides more continuity than the term "Cold War," which artificially frames us between 1946 and 1989. Really, this is a story that is rooted far earlier and ends far later. If we focus on the Cold War in a very rigid sense, we lose a lot of the story. My concern is that some of our interests get too tied to political aspects of the Cold War, which are artificially constructed anyway. We tend to think, Oh wasn't it terrible what happened to Liberals during the Cold War without considering the wider contexts and empathizing with the fear of Communism at the time and the Soviet Threat. There's little acknowledgment that there actually might have been a Soviet threat which, if unchecked would do terrible things to Hungarians, Czechs, and Poles.

(The generation growing up today finds it increasingly difficult to relate to the subject, now that the Soviet Union has fallen.)

(Jowett) When I show several of these films in propaganda classes, it's difficult for me to convince students that the Soviet threat was a very real one. And when you shows them documentaries on Soviet propaganda, they tend to find them laughable. At the same time, I ask them to go home and ask their parents and grandparents what it was like to live in the 1950s. They come back with remarkable stories about the kind of paranoia they lived under; that they were indeed fearful they might not wake up in the morning. That kind of paranoia was being distilled and instilled in America. Then we discuss the "duck and cover" thing. Clearly, throwing yourself under a desk was not going to save you from nuclear destruction. So the question becomes, why were they pushing that. What they were doing was trying to promote the illusion that the government cared and that you could be protected (which in fact, you couldn't!).

(Cull) Another issue that comes up is how unempowered people felt about the Cold War, and how difficult it was to participate in it. A lot of things that happen in Cold War and in Cold War culture is this promotion of the illusion of participation. "Duck and Cover" was one thing. But also, Cold War culture enables you the sense of participation. Novelists like John LeCarre provide such a way. Puzzling through the intrigues of his novels enabled you to feel you were participating vicariously in this struggle.

(Jowett) There's an interesting parallel in the great propaganda posters of World War One and World War Two. My students are always amazed when I show them things like variations on "Zip Your Lip." They ask me if there was really this serious Fifth Column threat. The answer is, absolutely not. It wasn't as if everybody were running around talking about troop movements and so forth. It was a way of getting you to participate in the war effort as a civilian.

(Cull) Therefore, audience awareness of the audience of these films is important. Films that were sent overseas likewise had the impact of involving those viewers with Americans.

(Jowett) We also have a parallel with the end of World War One with the decimation of the European film industry. During the 1920s, before sound came in, it was virtually dominated by the American film industry. We can trace the domination 
of Europe by American popular culture from then, and from the subsequent events that followed World War II. As much as might hate this, as much as there might be a lot of rhetoric about American cultural imperialism, the fact is that American popular culture is becoming increasingly dominant because of new technologies like television and satellites.

(Cull) At the same time, American popular culture has been very inclusive. Hollywood has also bought the best talent that's out there and absorbed it.

(Jowett) This is where the reality and the perception don't match. The perception is, these are basically American ideas being pushed off onto the world public. Where, in fact, increasingly, for survival, popular culture has to be internationalist in its approach to succeed. Here in America, we forget this. Look at our Monday morning habit of examining the morning newspapers for the movie box scores. Films are now rated on the basis of how much they pulled in last weekend, ignoring the fact that a film like Judge Dredd will have the international box office as its savior, and not that of the United States. Sixty percent of its boxoffice may be pulled in outside of the United States. So films are made with that larger boxoffice in mind-

(Cull) -Which explains all the violence and explosions that are there, because they don't need translation. International teams of filmmakers now come to bear on individual American productions. Independence Day had a German writer-American nationalism as only a German could imagine it!

(Jowett) What really concerns me in all of this discussion is how much of this really affected the public? We can talk all we want to about exposure to a message. But my training as a social scientist tells me we need to be very suspicious about what the so-called "reception" of these messages is. This vague term, "reception theory" should be replaced by "reception studies." We have yet to have a clear idea of how a message is likely to have somehow either influenced or not influenced people, and what is the process by which people are exposed to these images and subsequently react to them. Merely saying that there were a lot of movies and comic books with anti-Communist rhetoric doesn't mean that the public was buying in to all this.

(Meanwhile, the emphasis seems to be on the American contexts of the Cold War. What about other countries?)

(Jowett) I think that a conference like this inevitably has a concentration on blacklisting in Britain and America. But the notion that American popular culture was dominantly pushing this thing is a misnomer. I do not know that much about the history of Russian filmmaking in the Soviet block countries in this period as a countermeasure. Of course, we always have this image of heavy propagandistic film, which we know historically that audiences have never enjoyed. Subtle propaganda is much more effective than a heavy-handed one.

(Cull) I know the Soviets had stage shows satirizing western Cold War film. There was a James Bond stage show in 1965, where Bond would appear on stage to be attacked from various people, including a KGB agent emerging from the toilet!

(Was there an equivalent to HUAC in any other countries?)

(Jowett) That's a good question. Other American allies in NATO were subjected to similar kinds of suspicions in the sense that the American control of 
NATO extended that sort of investigation. But that's as far as it went. The HUAC thing is so difficult to get a handle on in terms of its influence. We can document precisely the things that happened in the hearings themselves, but the ethos that they created in America is one that is very difficult to fully assess.

(Cull) HUAC was public theater. The point was that it provided a public forum for these tensions to be worked out between new migrants and older Americans. The whole McCarthy thing was the revenge upon the older Americans by the newer Americans, the revenge of Irish and Catholic Americans on the establishment. To go to the Alger Hiss case, there were significant moments where on the witness stand the questions relate to his education and note is taken of his Oxford accent and his wearing of striped pants - things seen as "un-American," culturally - are tied to the extreme Liberal politics.

(Jowett) What the historian Richard Hofstadter called the "paranoid style" of American conservatism. That still is true today. There is a definitely an antiintellectual bias to American conservatism. Anyone perceived as a thinker rather than a doer is considered to be suspicious. We can go back a long way in American cultural history to perceive the whole role of culture as possessing a "feminist" kind of trait, one that puts you under suspicion - the "Ichabod Crane" phenomenon, if you willwhere being a teacher and a thinker, as opposed to a tinkerer and a doer, is considered suspect. So, when people thought and wrote about ideas, they were immediately suspicious. HUAC works out a lot of those tensions. The role of the intellectual came under enormous fire. Why the movies? That, I think, is clear. Hollywood provided the best public whipping boy in terms of publicity for HUAC. They very clearly went after Hollywood, even at a time when Hollywood was in decline in terms of its influence in America. To attack the great icons of Hollywood was a guarantee of frontpage news. They could have gone elsewhere, but they were guaranteed their image as "cleansers" by going after Hollywood.

(Jowett) Beginning with Hollywood in 1938, when HUAC first comes on the scene. Gerald P. Nye, in his very famous speech in 1939, talks about propagandizing at the boxoffice. He refers to "Europeans," a term he uses constantly, which is a thinly disguised anti-semitic notion. What resulted after that speech was an infamous, and rather hilarious Inter-State Commerce Committee hearing on propagandizing in the motion picture industry in 1940. That hearing was adjourned in October 1941 to reconvene in January 1942. But on December the $8^{\text {th }}, 1941$, the Committee was "permanently disbanded" because of Pearl Harbor. Those were fascinating hearings. What they did was highlight all the fears of conservative Americans about the potential power of the movies.

(Cull) What came out of those hearing was also that none of the representatives chairing the hearings had actually seen any of the movies they were talking about. Jack Warner asked them if they had seen the films, and the answer was no.

(It seems that few popular histories are telling this story to the general reader.)

(Jowett) When you say "popular history," academics cringe when you declare anything to be "popular." As an editor of a series of film books, I find that young scholars are discouraged from doing lengthy histories. Secondly, there is a feelingand I think this is totally wrong - that doing a lengthy history is a kind of easy way out; that what you need to do is spend five years of your life writing some sort of 
excruciating monograph on the presentation of pumpkin seeds in Invasion of the Body Snatchers as opposed to doing a large-scale history. There are some interesting academic politics here. One of them is that many are actively discouraged from taking on larger works. During the pre-tenure period, they're told to "get it out there" and "write as many works as you can." And for God's sake, don't take on something that will need several years, even though it might be an important contribution. Academic politics is actually intercepting the sort of work that should be done. As an editor, I'm constantly soliciting projects that get a scholar enthused, until he or she is discouraged by their department chair. For example, I've been turned down by five scholars on the subject of doing a book on "Feminism and Popular Culture," because their department chairs warn that it's too long, that it's a mistake to write a book for a series, that it's too controversial (and would annoy other, more senior scholars), and so forth. There's a lot of academic politics involved in why some books don't get done. Large-scale books are considered to be something you do in the year just before you retire!

(Cull) I can see what Garth is talking about. But personally, I have no trouble plugging away at my history of the United States Information Agency, from 1953 to the present. It's going to take me at least five years. And that's not considering some obstructions out there that might delay me. On the other hand, I already have tenure! I admit I might not have taken on such a project before I got tenure. But I would disagree with Garth to the extent that there is a crying need for more articles that do take on quite specific subjects. For example, you don't see so many things on just single films any more. That really go in to a single film, look at its script, examine its publicity, and assess the transformations of the script on the way to the screen.

(Jowett) I guess I am getting curmudgeonly. But I get annoyed at too much of what I read. I call it "feet on the desk" scholarship. I notice that a lot of young scholars don't do the leg work of actually trying to seek out the original source materials, go into the files. It's much easier to screen the film fifty times in your office than it is to go look up the production files.

(Cull) This coincides with certain critical ideas that the author's intentions have no significance. This gives a scholar the perfect theoretical justification for not going to the private papers of the author or the filmmaker, of not looking at studio and/or governmental records. Too much of what passes for today's scholarship leans in this direction.

(Jowett) I must say that Nicholas' book on the USIA promises to be quite significant. As somebody who's spent the last twenty years looking at the history of propaganda, I think that this is a major effort. The USIA has tended to do "self history" in the past. If you rely on the public histories, you get an increasingly distorted history of the Agency. You have to spend years going through all the documents, which they've never released.

(Cull) Here at the Conference I'll analyze the USIA's first feature, Years of Lightning, Day of Drums, as not only an obituary of a fallen President, and a key text of Kennedy's life, but as an example of how America fought the Cold War with the film medium. Although filmmaker Bruce Herschenson was a conservative, he was a favorite of Kennedy's. He was convinced that a documentary could be as vibrant and dramatic as any fiction film. Of course, for years this particular film, like other USIA films, could not be shown in the United States, due to USIA policy. But an Act of 
Congress in 1966 allowed it to be shown here. More recently, President Clinton has acted to allow any USIA film twelve or more years old to be shown to American scholars.

[Cull on his presentations points out the distortions in the Kennedy obituary: The footage of the march on Washington where crowd reactions to speakers are seen against footage of Kennedy's speech on civil rights. So you have the impression that Kennedy addressed the march on Washington.]

\section{SOME RECENT COLD WAR-RELATED PUBLICATIONS}

Redeeming the Wasteland: Television Documentary and Cold War Politics, by Michael Curtin (1995)

A five-year period of New Frontier documentaries on the three networks, ABC's Bell and Howell Close-Up!, NBC White Paper, and CBS Reports. Documentary felt to be an effective countering of Soviet propaganda and a means to "foster an imagined comradeship among citizens of the free world."

Hollywood's Other Blacklist, by Mike Nielsen and Gene Mailes (1995)

IATSE blacklisting after 1945.

Man Without a Face, by Anne McElvoy (1997)

"Spymaster" General Markus Wolf, one of the founders of the Die Hauptverwaltung Aufklaerung (HVA), the Main Intelligence Directorate of the GDR ("If I go down in espionage history, it may well be for perfecting the use of sex in spying.")

Operation Solo, by John Barron (1997) 
The story of Morris Childs, a respected member of the CPUSA, their liaison with the Kremlin leadership for 25 years, who actually was one of the most successful intelligence agents for the United States in the Cold War era..

Confessions of a Spy, by Pete Earley (1997)

The fifth and latest book about Aldrich Ames, a CIA worker turned spy for the KGB in the latter years of the Cold War.

Korea's Place in the Sun, by Bruce Cumings (1997)

The controversial book deals, in part, with his thesis that the American intrusion into the wreckage left by forty years of Japanese rule - which had already precipitated a barely contained civil war between North and South by 1948 - helped perpetuate and worsen the subsequent Korean War.

Gorbachev and His Revolution, by Mark Galeotti (1997)

Contrasts the forces for change that Gorbachev catalysed and unleashed within a stagnating and moribund Soviet regime.

Inside Out, by Walter Bernstein (1996)

A memoir by a blacklisted Hollywood writier.

McCarthyism, edited by Albert Fried (1997)

A compilation about the so-called "Great American Red Scare."

$\underline{\text { Secrets, }}$ by Paul Brodeur (1997)

A former New Yorker staff writer broods over the last forty years, the paranoid atmosphere that led to CIA's assassination plots against Castro, Nasser, and Sukarno; the trumped-up pretext for the Vietnam War, the FBI's wiretapping of Martin Luther King, Jr; the Watergate and Iran-contra scandals; the superfluousness of the invasions of Panama and Iraq.

We Now Know: Rethinking Cold War History, by John Lewis Gaddis (1997)

The dean of Cold War historians surveys new scholarship and confirms that it was Stalin who was primarily responsible for Cold War escalations. "Once it was clear his state would survive the way, then it looks. . . clear that there was going to be a cold war whatever the West did." Has this book come out too soon, though? There's still too many newly unearthed documents to sift through. . . .

Germany Unified and Europe Transformed: A Study in Statecraft, by Philip Zelikow and Condoleezza Rice 1997)

Claimed that the reunification of Germany within NATO was a triumph of American diplomacy. 
Inside the Kremlin's Cold War, by Vladislav Zubok and Constantine Pleshakov (1997)

One of the first systematic attempts to sift through newly released Soviet documents. It concludes that while it was Stalin whose miscalculations started the Cold War, American responsibility in continuing the struggle after Stalin's death cannot be discounted.

Age of Delerium, David Satter (1996)

A former Moscow correspondent argues that Communism was destined to fail by reason of its materialistic interpretation of mankind. It was brute social engineering. Glasnost, originally designed as another instrument of control, in actuality, through its publicizing of Stalinist crimes, revealed Communism itself as a historic mistake.

Reflections of a Cold Warrior: From Yalta to the Bay of Pigs, by Richard M. Bissell, Jr. (1997)

Revisionist views of two of the CIA's purported triumphs, overthrowing the Mossadegh regime in Iran in 1953 and the Arbenz regime in Guatemala in 1954. Indeed, the latter operation helped to mislead the CIA into backing the Bay of Pigs disaster in Cuba.

The Ghosts of Berlin: Confronting German History in the Urban Landscape, by Brian Ladd (1997)

History of the city.

Whittaker Chambers: A Biography, by Sam Tanenhaus (1997)

Hiss was guilty and Chambers was telling the truth.

The Last Division: A History of Berlin, 1945-1989, by AnnTusa (1997)

Critical of the "ineffectual and timorous behavior of the Western Powers" toward the Soviets in the Cold War. Western strategy was essentially defensive: "This meant that the Western allies might have been prepared to fight to maintain their hold on their sectors of Berlin, but not to prevent the Soviets from doing what they wanted in the East."

Dissolution: The Crisis of Communism and the End of East Germany, by Charles S. Maier (1997)

As opposed to The Last Division, Maier contends that in the long run the Western powers' patience paid off. Three changes--the steady decline in ideological commitment, the deterioration of the economy, the upheavals in European Communism that followed Mikhail Gorbacherv's efforts to reform the Soviet Union. Of the three, the collapse of the Communist bloc seems by far the most significant. A scholarly analysis of how and why the Communist regime in East Germany came apart and disappeared. A narrative of the last days of the GDR, not just the general failure of Communism, but as a reflection of a profound shift of late $20^{\text {th }}$ century society towards 
complexity, in which the simple models of central control of mid-century East and West simply failed. One particular problem was the GDR's inflexibility regarding economic policy.

\section{META-HISTORY}

A founding presupposition of Western historiography is the opposition of fact and fiction. Hayden White in "The Modernist Event" says that modernism has altered this, "abandoning the ground on which realism is construed as an opposition between fact and fiction." Therefore, "the taboo against mixing fact with fiction, except in manifestly 'imaginative' discourse, is abolished." (18) New genres, in both written and visual form have appeared. Their names are many - para-historical representation, docu-drama, faction, infotainment, historical metafiction. They are represented by books like Capote's In Cold Blood (1965), Mailer's The Executioner's Song (1979), Doctorow's Ragtime (1975); television shows like Roots (1977); and films like The Damned (1969), Our Hitler (1976-77), JFK (1991), and Schindler's List (1993). They all deal with historical phenomena, and all appear to "fictionalize" to a greater or lesser degree the historical events and characters which serve as their referents in history.

They differ from the $19^{\text {th }}$ century paradigm, where the "interference" between an imaginary tale of romance and a set of historical events were mediated by the presumed capacity of the reader to distinguish between real and imaginary events, between "fact" and "fiction." "Without this capacity, the affect in which the familiar (the reader's own reveries) was rendered exotic while the exotic (the historical past or the lives of the great) was rendered familiar could not have been produced." (18) However, the postmodernist docu-drama dissolves this contract. It puts in abeyanace the distinction between the real and the imaginary." (19) Everything is presented "as if it were of the same ontological order, both real and imaginary-realistically imaginary or imaginarily real. ..." (19) For example, Stone's JFK "seemed to blur the distinction between fact and fiction by treating an historical event as if there were no limits to what could legitimately be said about it, thereby bringing under question the very principle of objectivity as the basis for which one might discriminate between truth on the one side and myth, ideology, illusion, and lie on the other." (19) The so-called "new documentary" is, in the opinion of Linda Williams, less about "facts" than they are about the filmmaker's search for the facts. ( Linda Williams, "Mirrors Without Memories: Truth, History, and the New Documentary," Film Quarterly 46, No. 3 (Spring 1993), 13.)

Present generations have difficulty in arriving at agreement as to the meaning of events. In conventional historical inquiry, the facts established about a specific event were taken to be the meaning of that event. "But the facts are a function of the meaning assigned to events, not some primitive data that determine what meanings an event can have." (21) Facts and meanings are separate propositions. "What is at issue here is not the facts of the matter regarding such events but the different possible meanings that such facts can be construed as bearing." (21) 
Why has this happened? The notion of the historical event has undergone radical transformation because of two things - the occurrence in our century of events of a scope, scale, and depth unimaginable by earlier historians (like the Holocaust); and the dismantling of the concept of the event as an object of a specifically scientific kind of knowledge. The notion of "story" has "suffered tremendous fraying" (22) and potential dissolution by, among other things, the technologies of representation made possible by the electronics revolution. Regarding this last point: The modern electronic media can manipulate recorded images so as literally to "explode" events before the eyes of viewers. The intensive analysis to which the Rodney King tape was subjected, for example, "had the effect of making this seemingly unambiguously documented event virtually unintelligible as an event. The very precision and detail of the imagistic representation of the event are what threw it open to a wide variety of interpretations of 'what was really going on' in the scene depicted." (23)

How may we assess these New History films? In Revisioning History Robert A. Rosenstone insists that "film must be taken on its terms as a portrait of the past that has less to do with fact than with intensity and insight, perception and feeling, with showing how events affect individual lives, past and present. To express the meaning of the past, film creates proximate, appropriate characters, situations, images, and metaphors." (7)

This prefigures Pierre Sorlin's pronouncement fifty years later: "History is no more than a useful device to speak of the present time." (Sorlin, The Film in History: Restaging the Past (Totowa, N.J.: Barnes and Noble, 1980), 208) 